\begin{abstract}
UNIVERSIDADE DE SÃO PAULO
FACULDADE DE FILOSOFIA, LETRAS E CIÊNCIAS HUMANAS DEPARTAMENTO DE LETRAS MODERNAS PROGRAMA DE PÓS-GRADUAÇÃO EM ESTUDOS LINGÜÍSTICOS E LITERÁRIOS EM INGLÊS
\end{abstract}

\title{
A VISÃO DO SOBRENATURAL \\ NAS PEÇAS DE CONOR MCPHERSON
}




\author{
UNIVERSIDADE DE SÃO PAULO \\ FACULDADE DE FILOSOFIA, LETRAS E CIÊNCIAS HUMANAS \\ DEPARTAMENTO DE LETRAS MODERNAS \\ PROGRAMA DE PÓS-GRADUAÇÃO EM ESTUDOS LINGÜÍSTICOS E \\ LITERÁRIOS EM INGLÊS
}

\title{
A VISÃO DO SOBRENATURAL \\ NAS PEÇAS DE CONOR MCPHERSON
}

MARIA RITA TEIXEIRA SILVA KÖSTER

\begin{abstract}
Dissertação apresentada ao Programa de PósGraduação em Estudos Lingüísticos e Literários em Inglês, do Departamento de Letras Modernas da Faculdade de Filosofia, Letras e Ciências Humanas da Universidade de São Paulo, para obtenção do título de Mestre em Letras.
\end{abstract}

Orientadora: Profa. Dra. MUNIRA HAMUD MUTRAN

São Paulo 
Klaus, Yuri e Natascha,

com muito amor, pela compreensão e incentivo em todos os momentos desta caminhada. 


\section{AGRADECIMENTOS}

Agradeço a todos que, direta ou indiretamente, participaram comigo na elaboração desta dissertação.

À Profa. Dra. Munira Hamud Mutran, por sua valiosa orientação, pelas inúmeras leituras do meu trabalho, pela afeição, amizade e incentivo.

À Profa. Dra. Beatriz Kopschitz Xavier Bastos pela inspiração, amizade e todo apoio desde o início desta jornada.

À minha mãe e familiares pelo apoio e compreensão quando minha ausência se fez necessária.

À Profa. Dra. Zoraide Rodrigues Carrasco de Mesquita e à Profa. Dra. Maria Silvia Betti pelas sugestões e colaboração na banca de qualificação.

À Fabiana Rodrigues Dias pela amizade, companheirismo e preciosas sugestões.

À Sandra Mary Stevens pelo incentivo e carinho em todos os momentos.

Às amigas Elaine Rodrigues da Silva e Maria Eugênia D’Espósito pelas leituras, revisão e formatação.

Aos colegas do Grupo de Estudos Irlandeses (GEI) e aos membros da Associação Brasileira de Estudos Irlandeses (ABEI) com os quais tive oportunidade de conviver.

À Universidade de São Paulo e ao programa de Pós-Graduação em Estudos Lingüísticos e Literários em Inglês, pela oportunidade de desenvolver esta dissertação. 


\section{RESUMO}

A presente dissertação examina os diferentes elementos do sobrenatural encontrados em três peças do dramaturgo irlandês Conor McPherson: St Nicholas (1997), The Weir (1997) e The Seafarer (2006). Observa-se que o uso do sobrenatural é recorrente em sua obra, embora ele empregue elementos diferentes em cada uma das peças com o objetivo de retratar as angústias e os problemas existenciais do homem contemporâneo. St Nicholas é uma paródia das histórias de vampiros, em The Weir o autor recorre à tradição oral irlandesa do contador de histórias e em The Seafarer re-escreve a lenda de Fausto.

\section{PALAVRAS-CHAVE}

SOBRENATURAL - VAMPIRO - CONTAR HISTÓRIAS - MONÓLOGO - TEATRO IRLANDÊS 


\section{ABSTRACT}

The present dissertation examines different elements of the supernatural found in three plays by the Irish playwright Conor McPherson: St Nicholas (1997), The Weir (1997) and The Seafarer (2006). The supernatural is a recurrent feature in McPherson's work, although he makes use of different elements in each of his plays with the aim of depicting the anxieties and existential problems of contemporary man. St Nicholas is a parody of vampire stories; in The Weir the author resorts to the Irish oral tradition of storytelling; and in The Seafarer he rewrites Faust's legend.

\section{KEY WORDS}

SUPERNATURAL - VAMPIRE - STORYTELLING - MONOLOGUE -IRISH THEATRE 


\section{SUMÁRIO}

INTRODUÇÃO...........................................................................p. 08

\section{CAPÍTULO 1}

St. Nicholas: Um Crítico de Teatro entre Vampiros ...............................p.23

\section{CAPÍTULO 2}

The Weir: O Efeito de Histórias Sobrenaturais ..p.46

\section{CAPÍTULO 3}

The Seafarer: O Fausto Contemporâneo p.70

CONSIDERAÇÕES FINAIS. ..$p .94$

BIBLIOGRAFIA. ..p.104 


\section{INTRODUÇÃO}

O dramaturgo, diretor e roteirista de cinema Conor McPherson é um dos mais bem sucedidos representantes da mais jovem geração do teatro irlandês. Nasceu em Dublin em 1971 e em 1988 estudou filosofia e literatura no University College Dublin (UCD). Escreveu e dirigiu suas primeiras peças para o grupo de teatro amador Dramsoc da universidade: Taking Stock (1989), Michelle Pfeiffer (1990), Scenes Federal (1991) e Inventing Fortune's Wheel (1991). Em 1992, iniciou seus estudos de pós-graduação em filosofia e ética e criou uma companhia de teatro, Fly By Night com colegas do UCD. Para esse grupo, McPherson escreveu e dirigiu as peças Radio Play (1992), A Light in the Window of Industry (1993) e The Stars Lose Their Glory (1994) exibidas no International Bar no centro de Dublin. Embora tenha recebido elogios, McPherson considera essas primeiras peças como exercícios e não tem planos de encená-las novamente ou de publicá-las. 
Seu mestrado em filosofia resultou na dissertação "Logical Constraint and Practical Reasoning: On Attempted Refutations of Utilitarianism (1993)", cujo objetivo seria ilustrar os princípios que levam ao pensamento ético, discutindo teorias e conceitos ligados à justiça, à moral e virtudes. Quando estive em Dublin no University College (UCD) tive oportunidade de examinar esse trabalho que possui ampla bibliografia na área de ética e utilitarismo.

Embora tenha iniciado sua carreira de dramaturgo aos 17 anos, McPherson acredita ter "encontrado uma maneira própria de escrever" só em seu primeiro monólogo, Rum and Vodka, encenado em 1992 na universidade em Dublin (McPHERSON, 1999, p.179) *. Em outubro de 1994, McPherson foi agraciado com o Stewart Parker Award por The Good Thief (1994), peça apresentada no festival de teatro em Dublin. Este segundo monólogo também foi uma porta de entrada para o cinema, pois o produtor irlandês Robert Walpole e o diretor Paddy Breathnach, impressionados com o trabalho de McPherson, decidiram convidá-lo para escrever o roteiro de um filme, I Went Down (1997) - o filme foi premiado como melhor roteiro no festival de cinema em San Sebastian no mesmo ano.

Apesar do sucesso das duas peças, Conor McPherson cita seu terceiro monólogo - This Lime Tree Bower - como sendo o "grande impulsionador de sua carreira" (McPHERSON, 2004b, p.211) ${ }^{\dagger}$. Primeiramente encenado em 1995 no Crypt Arts Centre, em Dublin, foi transferido dez meses depois para o Bush Theatre em Londres, onde recebeu vários prêmios. (Thames TV Award, Guinness/National Theatre Ingenuity Award e Meyer-Whitworth Award). McPherson tornou-se, então, escritor residente do Bush Theatre, onde escreveu e encenou St. Nicholas (1997). No mesmo ano, publicou seus quatro primeiros monólogos pela editora londrina Nick Hern Books.

A partir dessa época, suas peças passam a ser produzidas primeiramente em Londres e depois transferidas para Dublin e remontadas nos Estados Unidos. The Weir, por exemplo, teve sua premiere no Royal Court Theatre Upstairs em Londres em 1997 e foi transferida para o Royal Downstairs em fevereiro de 1998; em julho foi encenada em Dublin, no Gate Theatre, e em 1999 estreou na Broadway. Todas as montagens de The Weir foram dirigidas por lan Rickson, mas o dramaturgo se fez

\footnotetext{
" "But Rum and Vodka is the play with which I think I found my voice."

+ "People will always associate me with the success of The Weir, but Lime Tree was where I felt I really hit something. Where it really connected with the audience. That was a huge play for me."
} 
presente na escolha do elenco, nos primeiros ensaios em Londres bem como em uma apresentação em Nova York (nesse caso, apenas como espectador). Outras peças que também alcançaram fama internacionalmente são: Dublin Carol (2000), Port Authority (2001), Come on Over (2001), Shining City (2004) e The Seafarer (2006). McPherson dirigiu também a peça Eden (2001) de Eugene O’Brien para o Abbey Theatre, e os filmes Saltwater (2001), baseado em sua peça This Lime Tree Bower, Endgame (2001) feito para a série Beckett on Film do Channel Four e The Actors (2003) com roteiro baseado numa história de Neil Jordan - cineasta e dramaturgo irlandês, diretor de Michael Collins - O Preço da Liberdade (1996) e Entrevista com o Vampiro (1994), entre outros filmes de sucesso.

Embora Conor McPherson seja um diretor de teatro e cinema, além de roteirista, nosso estudo tem como foco principal suas peças; não é nossa intenção examinar seus filmes em detalhe. Até o presente momento, McPherson publicou dez peças. Seus quatro primeiros monólogos foram incluídos em Conor McPherson: Four Plays, em 1999, com um posfácio do autor. Em Rum and Vodka (1992), um monólogo dividido em duas partes, o narrador relata o que lhe aconteceu nos três dias depois de ser despedido por beber durante o expediente. Em The Good Thief (1994), o protagonista conta o incidente que o levou a cumprir pena de dez anos por sequestro. Já em This Lime Tree Bower (1995), três narradores se intercalam expondo os acontecimentos que mudaram suas vidas. Em St. Nicholas (1997), o protagonista é um crítico de teatro que relata a época em que viveu na casa de vampiros em Londres.

The Weir (1997) foi a peça de Conor McPherson que recebeu maior atenção de público e crítica até o presente momento - ficou dois anos em cartaz em Londres. Em The Weir, os monólogos assumem mais a forma de storytelling, pois as personagens - o dono de um bar isolado no interior da Irlanda (Brendan), três clientes regulares (Jack, Jim e Finbar) e uma mulher (Valerie), que acaba de se mudar de Dublin para uma casa da região, contam histórias sobrenaturais enquanto tomam cerveja.

Em 2004 The Weir foi republicada em uma segunda coletânea sob o título, McPherson Plays: Two, incluindo também as peças: Dublin Carol, Port Authority e a inédita Come on Over, juntamente com um posfácio do autor. Em Dublin Carol (2000), o agente funerário John Plunkett conversa com seu assistente Mark e relembra os funerais de que já participou. John recebe, então, a visita de sua filha 
Mary forçando-o a fazer uma retrospectiva de sua própria vida, revelando oportunidades perdidas e promessas não cumpridas. Em seguida, marcam um encontro para mais tarde, a fim de juntos irem visitar a mãe de Mary, ex-esposa de John, que está hospitalizada com câncer em fase terminal. Em Port Authority (2001), McPherson retorna à forma de monólogo com três narradores que se alternam para contarem episódios de suas vidas. Kevin, vinte anos, sai da casa dos pais para morar com uns amigos e sua amiga, Clare, por quem está apaixonado. O segundo narrador, Dermot, com cerca de trinta e cinco anos, nos primeiros dias de seu novo emprego, descobre que só obteve o lugar porque seu empregador o confundiu com outra pessoa. O terceiro narrador, Joe, setenta anos, mora num lar para idosos e recebe um pacote misterioso, que o faz relembrar uma breve paixão, nunca declarada, pela mulher de seu vizinho, anos atrás. A última peça deste volume Come on Over (2001), foi encenada para o festival de teatro de 2001 em Dublin como parte de um espetáculo intitulado Three New Irish Plays, juntamente com The Yalta Game, de Brian Friel e White Horses, de Neil Jordan. Come on Over é a história de Matthew e Margaret, namorados na adolescência, que se re-encontram aos cinquenta anos. Ele é um jesuíta que investiga milagres para o Vaticano e ela gerencia uma pousada na zona rural da Irlanda. Matthew é enviado para investigar o corpo de uma menina preservado por 400 anos e, durante sua última noite na pousada de Margaret, trocam carícias íntimas. No início da peça, os dois atores, encapuzados, falam diretamente com a platéia; a partir da metade da peça até sua conclusão se entreolham e dialogam breve e esporadicamente.

A nona peça de McPherson, Shining City (2004), foi uma co-produção do Royal Court Theatre, em Londres e do Gate Theatre em Dublin. Sob a direção do autor, foi encenada primeiramente no Royal Court Jerwood Theatre Downstairs em julho de 2004 e teve sua premiere no Gate em setembro de 2004. Já em maio de 2006, Shining City estreia no Biltmore Theatre em Nova York, sob a direção de Robert Falls e posteriormente em Chicago no Goodman Theatre, sob a mesma direção. Em Shining City, estamos em Dublin e John, perturbado pela morte recente da esposa (Mari), cujo fantasma está vagando pela casa, procura o psicólogo lan que - cheio de problemas - também busca um novo caminho para sua vida. Ao longo da peça, encontramos mais duas personagens: Neasa, ex-esposa de lan e mãe de sua filha Aisling, e Laurence, garoto de programa que irá proporcionar a lan sua primeira experiência homossexual. Observa-se em Shining City o encontro entre o 
real e o irreal, o medo, o desejo e a culpa, enfim os sentimentos que percorrem os labirintos da alma numa luta que irá contribuir para definir dois homens - paciente e terapeuta - e mudar o rumo de suas vidas. No final, depois que John entrega um presente de agradecimento para lan e vai embora, o terapeuta permanece em cena empacotando suas coisas, pois também está de partida. Está um tanto escuro, tratase de fim de tarde e vemos o fantasma de Mari aparecer por trás de lan, vestindo as mesmas roupas descritas por John na primeira cena e também com os cabelos molhados. Ian vira-se, como se pressentisse alguma coisa e apagam-se as luzes.

A mais recente peça de Conor McPherson, The Seafarer, teve sua premiere em Londres no auditório Cottesloe do National Theatre em setembro de 2006. Depois, de fevereiro a março de 2007, saiu em turnê pela Inglaterra com apresentações em Brighton, Bath, Cambridge, Coventry, Salford e Newcastle. Em dezembro de 2007, estreou no Booth Theatre em Nova York e ficou em cartaz até março de 2008. E finalmente, em maio de 2008 vai para o Abbey Theatre em Dublin, numa curta temporada, devendo retornar em dezembro de 2009. A peça se passa numa casa velha em Baldoyle, que fica na costa norte da cidade de Dublin. É véspera de Natal e Sharky está de volta para cuidar de seu irmão Richard que ficou cego recentemente. Os amigos Ivan e Nicky aparecem e trazem o estranho senhor Lockhart para um jogo de cartas. No fim do primeiro ato, somos informados de que há vinte e cinco anos Sharky e Lockhart já haviam jogado cartas juntos e que agora Lockhart quer a revanche; descobrimos que é a alma de Sharky que está em jogo e Lockhart seria o demônio, que veio buscá-la.

Embora Conor McPherson tenha sido aclamado como um dos mais recentes gigantes literários da Irlanda (CUMMINGS, 2000, p.304) ${ }^{*} \mathrm{e}$ tenha dez peças publicadas, muitas delas com duas ou três montagens em diferentes cidades e países, sua fortuna crítica ainda não é tão ampla. Apesar de muitas resenhas publicadas em jornais sobre suas peças, os trabalhos acadêmicos relacionados à sua obra não são tão numerosos. Contudo, podemos dizer que a fortuna crítica do dramaturgo está se expandindo gradativamente.

Em 2003, foi lançado o primeiro livro inteiramente dedicado ao seu trabalho, Conor McPherson: Imagining Mischief de Gerald C. Wood. Nesse livro, Gerald Wood analisa detalhadamente oito peças de McPherson, de Rum and Vodka (1992)

\footnotetext{
* "In London and New York, he was, before the age of thirty, Ireland's latest literary giant" (CUMMINGS, 2000, p.304).
} 
até Come on Over (2001). As peças Shining City e The Seafarer ainda não haviam sido escritas. O livro inicia-se com uma cronologia da vida e obra do autor desde seu nascimento em 1971 até o futuro lançamento de The Actors (2003), filme que não é muito discutido por Wood. Na introdução, o crítico expõe brevemente a fase inicial da obra de McPherson. O segundo capítulo é dedicado à análise dos quatro primeiros monólogos: Rum and Vodka (1992), The Good Thief (1994), This Lime Tree Bower (1995) e St. Nicholas (1997). Cada uma dessas peças é vista como diferente e experimental, revelando a afinidade natural de Conor McPherson com a figura do tradicional contador de histórias irlandês, o Seanchaí ou shanachee*. No terceiro capítulo, destinado exclusivamente a análise de The Weir, há uma reflexão sobre o título e algumas informações sobre a recepção dessa peça de McPherson. Em seguida, os filmes I Went Down e Saltwater são discutidos; este capítulo também contém uma breve descrição da adaptação que McPherson fez da peça Endgame para o projeto Beckett on Film e algumas informações sobre The Actors, ainda em manuscrito na época da análise. No quinto capítulo intitulado Recent Plays: Nowhere Except Towards Each Other, Wood discute Dublin Carol (2000), Port Authority (2001) e Come on Over (2001), concluindo que estas peças mostram que McPherson continua experimentando novas formas teatrais como, por exemplo, 0 uso de monólogos intercalados em Port Authority, onde são relatadas histórias de vida diferentes. Wood também menciona a temática do dramaturgo, ele explica que nas três peças acima citadas, as personagens dão os primeiros passos em direção à responsabilidade perante suas próprias vidas; o que contrasta com os protagonistas dos dois monólogos iniciais, Rum and Vodka e The Good Thief. Nas peças mais recentes as personagens já demonstram empatia e compaixão pelas outras, também segundo o autor, algumas aceitam suas limitações e percebem a necessidade de buscar ou aceitar ajuda, enquanto outras notam que devem se cuidar melhor e ajudar seus familiares. No sexto capítulo, o crítico procura definir se podemos considerar McPherson um escritor irlandês típico, comentando que ele faz parte de um novo tipo de exílio irlandês, aquele em que o escritor continua morando na Irlanda, mas seus trabalhos são lançados em Londres num primeiro momento e com temas que também buscam uma universalidade. Inicialmente, as peças de McPherson não foram recebidas de braços abertos dentro da Irlanda, pois

\footnotetext{
* Seanchaí ou shanachee, denominação dada ao tradicional contador de histórias irlandês. (MARCUS, 2007, vii).
} 
obscenidades, fuga da forma dramática tradicional - onde a ação se desenrola principalmente através do diálogo entre os protagonistas - e fins inesperados eram vistos com estranhamento pelo público irlandês; no entanto, na Inglaterra e nos Estados Unidos, estes aspectos foram recebidos positivamente como um sinal da natureza experimental do trabalho de McPherson, que é tido como um autor de comédias dotado de uma visão própria. Ainda que McPherson faça uso do humor em suas peças, não acreditamos que as mesmas possam ser rotuladas de comédias. O aspecto mais importante deste livro dedicado a obra de Conor McPherson é uma entrevista com o dramaturgo realizada em dois momentos, junho de 2001 e novembro de 2001. Na primeira parte, McPherson discute o processo criativo de seu trabalho, explica que as ideias para as histórias aparecem como se fossem um filme. O dramaturgo comenta que se a história se passa em um só lugar como em Dublin Carol e The Weir - ele dá preferência para a forma dialogada, mas se a história acontece em ambientes diversos, ele recorre ao monólogo ou mesmo ao filme. McPherson explica que procura escrever por períodos de no máximo uma hora; no entanto, entre um período e o próximo fica pensando em todos os aspectos da história que está sendo trabalhada e costuma revisar seus textos até mesmo durante os ensaios quando aceita a colaboração dos atores na hora de omitir falas consideradas desnecessárias.

As soon as actors start saying what I have written, I see how much of it I don't need. I just know when an actor's doing something more naturally than I've written. If I've got good judgement, and I hope I do, I am going to throw out my precious thing, my precious joke, whatever it is, which no one is getting. ... If things are left unsaid, you wonder about them more just as you wonder about real people. (McPHERSON, apud WOOD, 2003, p.125)

Pode-se observar que o dramaturgo considera seu texto terminado somente depois do início da produção da peça; durante os ensaios, falas e cenas são alteradas. A entrevista prossegue com comentários sobre as peças Dublin Carol, Port Authority e Come on Over, bem como sobre seus filmes.

A bibliografia de Imagining Mischief contém artigos publicados em livros, jornais e revistas sobre a obra do autor. Observa-se que há mais resenhas das peças do que artigos propriamente ditos e só dois deles haviam sido publicados em 
livros; os livros mencionados são The Full Room: An A-Z of Contemporary Playwriting de Dominic Dromgoole e Theatre Stuff: Critical Essays on Contemporary Irish Theatre editado por Eamonn Jordan. No entanto, há um número considerável de resenhas das peças e filmes publicadas principalmente nos jornais: New York Times, Irish Times, The Times, Times Literary Supplement e The Guardian ou em revistas, tais como Variety, Village Voice e Time Out New York.

Em Theatre Stuff: Critical Essays on Contemporary Irish Theatre (2000) o artigo de Scott T. Cummings, "Homo Fabulator: the narrative imperative in Conor McPherson's plays", examina brevemente os monólogos Rum and Vodka (1992), The Good Thief (1994), This Lime Tree Bower (1995) e St. Nicholas (1997) e, com mais detalhes, a peça The Weir (1997). O principal tópico abordado é a importância crucial de histórias nas relações humanas: as histórias contadas em The Weir, por exemplo, têm o poder de consolar em casos de perdas, solidão e arrependimentos, tornando-se pontes que interligam as vidas das personagens da peça. Consideramos o artigo de Cummings de suma importância na análise crítica da peça The Weir.

Nicholas Grene cita Conor McPherson na conclusão de seu livro The Politics of Irish Drama: Plays in context from Boucicault to Friel (1999), explicando que The Weir não pode ser vista só como uma peça sobre a Irlanda, embora apresente temas que sempre estiveram relacionados ao país, tais como oposição entre rural e urbano, celibato ou casamento tardio entre os homens e a visão da mulher como objeto de desejo sexual numa sociedade reprimida. Para Nicholas Grene, tais temas e o cenário da peça, um pub irlandês na isolada área rural, chamam a atenção do público de Londres, Nova York e até mesmo de Dublin, pois a visão romântica e mistificada da Irlanda rural ainda é bastante presente para algumas pessoas que vivem em grandes centros urbanos. Segundo o crítico, o drama irlandês tornou-se uma moeda no mercado internacional de entretenimento e esse fenômeno é capaz de gerar dois tipos de resultados: por um lado, permite que escritores de talento como Frank McGuinness, Sebastian Barry e Conor McPherson atinjam sucesso rapidamente; por outro lado, faz com que dramaturgos de originalidade duvidosa, como Martin McDonagh, alcancem sucesso manipulando essa 'fórmula' da peça irlandesa que já é bem conhecida. Não compartilhamos a ideia de que McDonagh explore estereótipos irlandeses, com a intenção de "vender" mais o seu trabalho. A 
nosso ver, suas peças retratam a problemática do individualismo humano de uma forma diferente e com uma visão mais pessimista do que McPherson.

Em artigo publicado no Brasil no livro Kaleidoscopic Views of Ireland, editado por Munira Mutran e Laura Izarra em 2003, Nicholas Grene volta a citar McPherson, desta vez como sendo o dramaturgo mais comprometido com o monólogo no drama irlandês contemporâneo. Grene avalia como o espaço é representado no drama irlandês; começando com as peças de W.B.Yeats, J.M. Synge e Lady Gregory, onde a cottage kitchen ou o pub, no palco, também representam uma comunidade ou até a nação - a Irlanda - ou seja, o particular é universalizado. Grene segue comentando a representação de um auditório no palco, como em Faith Healer de Brian Friel e em Port Authority, com a rubrica de McPherson, "The play is set in the theatre" - a peça se passa no teatro. Aqui não há mais a quarta parede e os três personagens-narradores dirigem-se ao público, sem interação entre eles, sem movimentos de cena e sem efeitos visuais. O que importa agora é a história a ser contada. Para Grene, essas narrativas são como fábulas sobre identidade, amor e falta de amor, emoções individuais e universais ao mesmo tempo. O teatro torna-se então o espaço onde essas narrações em tom confessional acontecem e, ao invés de representarem a comunidade ou nação, essas narrativas se auto-representam.

No artigo "Ireland in Two Minds: Martin McDonagh and Conor McPherson", publicado em 2006 num livro sobre a obra de Martin McDonagh, Nicholas Grene traça um paralelo entre a primeira peça de McDonagh, The Beauty Queen of Leenane (1996) com The Weir e mostra que as duas peças representam visões diferentes e estereotipadas da Irlanda que estão presentes no imaginário do público. Num primeiro momento, Grene explica que tanto The Beauty Queen of Leenane quanto The Weir mostram a Irlanda rural do ponto de vista da cidade; pois, McDonagh e McPherson são autores que vivem em Londres e Dublin e passavam as férias escolares no campo, na região de Connemara, oeste da Irlanda. Para o crítico, o tema central de The Beauty Queen of Leenane é a relação violenta entre mãe e filha como uma forma de desmistificar a Irlanda rural; segundo ele, este tema já foi explorado em peças anteriores com, por exemplo, Bailegangaire (1985) de Tom Murphy. Embora não possamos descrever o pub como idílico, The Weir possui uma atmosfera bem diferente do tédio e brutalidade expressos na Lennane de

\footnotetext{
CHAMBERS, L. \& JORDAN, E. (Eds.).The Theatre of Martin McDonagh: A World of Savage Stories. Dublin: Carysfort Press, 2006, 42-59.
} 
Beauty Queen; a micro-comunidade que encontramos no pub de The Weir é gentil e acolhedora. Outro ponto destacado no artigo é o fato de que as duas peças retratam o fim da década de 90; porém, os dramaturgos trabalham com a oposição o antiquado versus o moderno de maneira diferenciada. Enquanto Beauty Queen está centrada no conflito entre o arcaico e o moderno, pois as personagens estão presas entre o passado mítico sufocante e as banalidades modernas assistidas pela televisão, The Weir procura derrubar essa diferença, ao mostrar que solidão, abandono, perversão sexual e morte são experiências humanas comuns tanto na vida rural quanto na vida urbana, tanto no passado quanto no presente. O terceiro ponto mencionado por Grene refere-se à oposição entre conflito e consolação. Beauty Queen, com toda sua violência, representa o conflito, ainda tão presente para muitas pessoas quando se fala em Irlanda. The Weir, no entanto, simula a solidariedade encontrada em comunidades pequenas que vivem em lugares remotos. Deste modo, Beauty Queen representaria a visão da Irlanda sempre em conflito e The Weir a Irlanda pastoral, um lugar a parte, onde se pode encontrar a inocência dos tempos pré-modernos. Grene comenta que o fato destas duas visões diferentes ainda serem tão presentes, explica a razão do sucesso de duas peças tão distintas. Para ele, aqueles que apreciam a peça de McDonagh devem achar a de McPherson muito sentimental; e os que gostam de The Weir, acham Beauty Queen cruel.

Nicholas Grene não é o único a comparar essas duas peças; Brad Kent, da Concórdia University em Montreal, examina as mesmas peças em seu artigo intitulado "McDrama: The sentimental in Martin McDonagh's The Beauty Queen of Leenane and Conor McPherson's The Weir" publicado na edição dupla do periódico Canadian Journal of Irish Studies em 2003. Para ele, o fato de as peças estarem situadas no oeste da Irlanda, região dos cartões postais e calendários, terra de mitos e fadas e a área mais procurada por turistas, reforça ideias estereotipadas do que é ser irlandês e da Irlanda tida como autêntica e sentimental. Kent acredita que ao procurar derrubar tais estereótipos, as peças acabam por reforçá-los e ambas fazem sucesso internacionalmente porque os irlandeses, sua terra e sua cultura são tidos como mercadorias valiosas no turismo cultural.

The Weir também é analisada detalhadamente no artigo de Eamonn Jordan, "Pastoral Exhibits: Narrating Authenticities in Conor McPherson's The Weir", publicado em 2004 no periódico Irish University Review vol. 34 n.2. Eamonn Jordan 
considera a peça como meta-pastoral; ele explica que as histórias narradas retomam o passado, dando-Ihe uma nova coerência e delineando novas posições as personagens na sequência de suas vidas. Interessante observar que é a história de Valerie - personagem vinda da cidade - que irá gerar mudança nas outras personagens, pois é apenas através de sua narrativa que os moradores do campo enfrentam suas realidades. Eamonn Jordan também examina a função do espaço narrativo, o bar ou pub, lugar comunitário e isolado, que se torna um elemento chave para promover o relaxamento necessário a essa troca de experiências pessoais, moldadas como narrativas, que representariam portas de entradas para um mundo privado e realidades que não seriam acessíveis através de interações como o diálogo comum.

Em Critical Moments: Fintan O'Toole on Modern Irish Theatre (2003), editado por Julia Furay e Redmond O'Hanlon, há uma resenha de The Weir referente à noite de lançamento em Nova York no Walter Kerr Theatre em abril de 1999. Fintan O'Toole esclarece que não há um enredo complexo, não acontece nada durante a peça, as personagens se encontram em um pub, contam suas histórias enquanto bebem e saem no final. No entanto, as histórias sobrenaturais criam um caminho para explicar os sentimentos diante da perda de um ente querido. Para O'Toole, o eixo central de The Weir é a morte e a necessidade de encontrarmos uma linguagem apropriada para que possamos expressar os sentimentos que veem à tona diante dela. Fintan O'Toole conclui que a peça traz um senso de dignidade profundo, mostrando que, as vezes, o que nos assombra não são os fantasmas e sim a memória dos que nos deixaram.

Em Ireland on Stage: Beckett and After (2007), editado por Hiroko Mikami, Minako Okamuro e Naoko Yagi, o artigo de Naoko Yagi, "Multiple Monologues as a Narrative: From Beckett to McPherson", examina o uso do monólogo no teatro de Samuel Beckett, Harold Pinter, Brian Friel e Conor McPherson. Em sua análise, Yagi menciona brevemente This Lime Tree Bower (1995) e se atém mais a Port Authority (2001), onde as personagens Kevin, Dermot e Joe narram histórias bem particulares de suas vidas dentro do teatro - que acaba adquirindo uma conotação quase religiosa - com o palco transformando-se num grande confessionário e o público/espectadores assumindo o papel de padre/ouvinte. Este artigo é útil para analisarmos a questão do monólogo também nas outras peças de McPherson, pois pode-se verificar que tais comentários aplicam-se às demais peças do dramaturgo. 
Em Suspect Cultures, Clare Wallace (2006b) também analisa os monólogos de McPherson no capítulo intitulado "Solitary Micronarratives", no qual a autora examina mais detalhadamente St Nicholas porque, segundo ela, é uma peça que levanta questões pertinentes para a compreensão de toda a obra inicial do dramaturgo. Wallace investiga o uso do monólogo como recurso para a quebra de ilusão e lembra que forma e conteúdo estão entrelaçados nas narrativas das peças iniciais do autor. Num outro livro editado por Clare Wallace (2006a), Monologues Theatre, Performance, Subjectivity, encontramos três artigos que abordam o uso do monólogo e narrativas no teatro irlandês da década de 1990. "Look Who's Talking, Too: The Duplicitous Myth of Naïve Narrative", de Eamonn Jordan, fornece uma explicação muito interessante para a proliferação dos monólogos na Irlanda contemporânea e identifica quatro tipos diferentes de monólogos nessa década, exemplificando com algumas peças de McPherson. No segundo artigo intitulado "Am I Talking to Myself? Men, Masculinities \& the Monologue in Contemporary Irish Theatre", Brian Singleton discute: Howie the Rookie, de Mark O'Rowe; Cold Comfort, de Owen McCafferty; bem como as peças: Rum and Vodka, This Lime Tree Bower e Port Authority de Conor McPherson. O terceiro artigo, significativo para este trabalho, é 'Will the 'Wordy Body' Please Stand Up? The Crises of Male Impersonation in Monological Drama - Beckett, McPherson, Eno", de Eckart VoigtsVirchow e Mark Schreiber. Segundo os autores, nas peças de McPherson, a forma de monólogo representa uma maneira de compartilhar narrativas entre ator, platéia e escritor, e a maioria das histórias tem como temática a crise da masculinidade, pois o dramaturgo leva ao palco personagens masculinas perdidas e sem esperanças, que precisam desesperadamente dividir suas angústias com o público.

Encontramos breves referências a Conor McPherson no livro de Christina Hunt Mahony, Contemporary Irish Literature: Transforming Tradition (1998) e em The Full Room: An A-Z of Contemporary Playwriting (2002) de Dominic Dromgoole Ambos consideram o dramaturgo como uma voz promissora no teatro contemporâneo.

A apresentação do que já se escreveu sobre Conor McPherson reveste-se de importância porque o dramaturgo ainda é pouco conhecido entre o público brasileiro; esperamos com este trabalho proporcionar possibilidades para futuros estudos e traduções de sua obra. 
Cinco das dez peças de Conor McPherson publicadas até o presente momento têm elementos do sobrenatural; todavia, nenhum artigo lido trata tal aspecto em profundidade. Além disso, The Seafarer ainda não recebeu atenção da crítica. Portanto, por se tratar de um recurso tão recorrente na obra do dramaturgo e ainda pouco abordado por críticos e estudiosos, escolhemos como foco de nossa pesquisa a visão do sobrenatural na obra de Conor McPherson.

O termo sobrenatural é utilizado para designar algo que foge do padrão, inusitado, capaz de gerar medo ou estranhamento por ser incomum; as pessoas costumam temer o que não conhecem e por isso algo considerado fora do comum pode ser tão espantoso. Segundo Marie Mulvey-Roberts (1998), em The Handbook to Gothic Literature, esse termo engloba todas as áreas além do mundo natural, sendo geralmente usado para nomear criaturas fantásticas e forças demoníacas que possam existir em dimensões paralelas às forças que regem nossa existência física. A crença no sobrenatural parece ser uma característica de praticamente todas as sociedades; embora o significado possa diferir de uma comunidade para outra, existe um consenso de que as criaturas e forças sobrenaturais possuem algumas habilidades específicas, tais como atravessar a fronteira entre a vida e a morte, transcender os limites entre o tempo e o espaço, mover entre o visível e o invisível, viajar entre o mundo espiritual e material. Ainda, segundo a autora, os seres do mundo sobrenatural possuem muitos poderes e são capazes de se manifestar para os seres humanos por sua própria vontade ou se forem invocados. Essas forças invadem o mundo real - o plano humano ou terreno - em forma de acontecimentos espantosos, horripilantes ou mesmo como milagres. Portanto, podem ser forças satânicas - representantes do Mal - ou forças do Bem: como anjos ou guias espirituais.

Ao falar em sobrenatural, lembramos da chamada ficção gótica, que despontou no século XVIII, na Inglaterra, com a obra The Castle of Otranto, de Horace Walpole, publicada em 1764, e que tinha como subtítulo a expressão: $A$ Gothic Story. Os principais elementos dos contos góticos seriam ambientes sombrios como ruínas e castelos medievais e seus respectivos porões, criptas e passagens secretas, habitados por fantasmas, demônios, esqueletos e outras criaturas sobrenaturais; bem como personagens enigmáticas e misteriosas, sendo que geralmente as personagens femininas encontravam-se em apuros para serem 
salvas pelo herói. Outros autores frequentemente associados ao gênero gótico são: Ana Radcliffe, Mathew Gregory Lewis e Mary Shelly. Jeffrey N. Cox observa que o drama gótico, embora não tão estudado quanto os romances, também era popular no fim do século XVIII e Horace Walpole escreveu a primeira peça considerada gótica, The Mysterious Mother (1768). No entanto, a maioria das peças góticas eram adaptações dos romances e contos; durante a década de 1790, o foco na personagem herói-vilão - aristocrata carismático, torturado e violento - oferecia um tipo diferenciado de tragédia, pois "mesclava o drama sério com outras formas como a comédia, o romance e a ópera" (COX, 1998, p. 75). Segundo Massaud Moisés, considera-se o "fim do período áureo da ficção gótica a narrativa Malmoth the Wanderer, publicada em 1820, do irlandês Charles Robert Maturin" (2004, p.212); esta obra é uma mistura de Fausto com a legendária figura do Judeu Errante.

W. J. McCormack (1992), em Irish Gothic and After, observa que Charles Robert Maturin (1782-1824), Joseph Sheridan Le Fanu (1814-73) e Bram Stoker (1847-1912) são sempre lembrados como os três maiores representantes da literatura gótica irlandesa; no entanto, o estudioso refuta a ideia de que exista na Irlanda uma "tradição" gótica nos mesmos moldes da literatura gótica da Inglaterra. Ele acredita que na Irlanda, alguns escritores abordaram certas situações que historicamente eram específicas do país, utilizando-se de elementos góticos em seus trabalhos, como por exemplo, a aparição de fantasmas, vampiros, fadas ou outros seres do mundo sobrenatural.

Parte desse mundo sobrenatural pode ser visto nas peças de Conor McPherson. Ao longo de nossa pesquisa foi recorrente a pergunta: com que intuito o dramaturgo usa tão largamente o sobrenatural no fim do século $X X$ e início do $X X I$, era da ciência e tecnologia? A escolha de nosso estudo recaiu em três peças nas quais os elementos sobrenaturais predominam e permeiam a trama: St. Nicholas (1997), The Weir (1997) e The Seafarer (2006).

Depois de ter escolhido as três peças, nossa proposta foi identificar os diferentes elementos do sobrenatural nelas presentes, buscando em textos literários ou do folclore irlandês as fontes de McPherson. Acreditamos que o dramaturgo não tenha por objetivo a recuperação da tradição de contar histórias, mas sim que ele se utiliza de narrativas com a presença de seres sobrenaturais para chamar a nossa atenção 
para temas que afligem a humanidade, como por exemplo, a solidão, o medo da morte e as crises existenciais do homem contemporâneo.

No capítulo 1 examinaremos St. Nicholas, com reflexões sobre o uso do tema do vampiro nessa peça e utilizando o conceito de paródia na definição de Linda Hutcheon e Afonso Romano Sant'Anna. O capítulo 2 investigará o efeito das histórias sobrenaturais nas personagens de The Weir, conjeturando sobre a tradicional figura do contador de histórias na Irlanda e as possíveis ligações com narrativas do folclore irlandês. No capítulo 3 analisaremos a peça The Seafarer, refletindo sobre as fontes empregadas pelo dramaturgo para compor seu Fausto contemporâneo; para tanto, utilizaremos o conceito de intertextualidade sugerido por Julia Kristeva citado por Sandra Nitrini e Leyla Perrone-Moisés. 


\section{CAPÍTULO 1}

\section{St. Nicholas: Um Crítico de Teatro entre Vampiros}

There was life before the vampires and life after the vampires.

Ben Brantley ${ }^{*}$

Das peças escolhidas para o presente estudo, St Nicholas é a primeira em que aparecem elementos do sobrenatural. Ela foi escrita durante o período em que o dramaturgo era escritor residente do Bush Theatre em Londres. Em suas peças iniciais, Conor McPherson quase não faz uso de rubricas, talvez porque ele mesmo tenha dirigido todas as primeiras montagens. As duas únicas rubricas de St Nicholas indicam que o palco está totalmente vazio e que a personagem é um homem de cerca de sessenta anos, cujo nome nós nem sabemos. Entretanto, o autor explica no posfácio que, enquanto estava escrevendo a peça, tinha sempre em mente o escocês Brian Cox para representá-la; e que havia até retirado de uma revista uma foto do ator e colado-a na pasta que usava durante o processo criativo. Na época da escolha do protagonista, McPherson conversou longamente com o diretor artístico

\footnotetext{
* BRANTLEY, Ben. Theater Review: A Most Dramatic Drama Critic. New York Times, 18/03/1998. Disponível em:<http://theater.nytimes.com/mem/theater/treview.html?res=9E04E3D61339F93BA2575 OCOA96E958260>. Acesso em: 21/10/2008.
} 
Mike Bradwell antes de decidirem enviar o script para Brian Cox, que estava fazendo um filme em Hollywood na época. Ambos achavam que seria quase impossível um ator tão ocupado aceitar o papel; ficaram surpresos quando Brian ligou para acertar as datas dos ensaios (McPHERSON, 1999, p.188). Brian Cox, com ajuda de um especialista, trabalhou muito para reproduzir o sotaque irlandês e St Nicholas foi bem recebida pelo público e pela crítica. Na maioria das resenhas, como em The London Times, foi mencionada a apropriada escolha do ator que, além de ser uma presença forte no palco, soube ressaltar o lado humorístico da obra.

Brian Cox has the audience in the palm of his hand. Not for a moment does he or the play let our attention drop. St. Nicholas has mystery, mischief, humour, suspense, surprise... wholly riveting*!

A narrativa, um monólogo de um único ator num palco vazio, é muito simples. Um crítico de teatro, mal-intencionado, pouco sério, detestado e temido pelas críticas cáusticas que escreve antes mesmo do término dos espetáculos; apaixona-se pela atriz Helen que faz o papel principal numa encenação de Salomé no Abbey Theatre. Para atraí-la, diz que escreveu uma crítica favorável à peça, embora tenha feito o oposto, e com isso tenta encantá-la. Embora seja casado, tenha um casal de filhos e more numa casa confortável em Dublin, decide abandonar a família e ir para Londres, onde a atriz se apresentaria por duas semanas. Em Londres, conhece William, um vampiro que mora numa casa velha e decadente no subúrbio com cinco mulheres, também vampiras. O narrador é então contratado por William para atrair jovens; passa as noites indo a festas e bares procurando mais vítimas para seu mestre. Em uma de suas andanças, re-encontra-se com a atriz Helen e a leva para casa de William. Vendo-os juntos decide salvá-la e volta para esposa e filhos. Entretanto, o protagonista-crítico comenta que o mais importante dessa experiência é que agora ele tinha uma história para contar.

Mas por que no fim do século $X X$ mais uma peça sobre vampiros? É impossível não relacionar William, o vampiro de St Nicholas, com a famosa personagem criada pelo escritor irlandês Bram Stoker no romance Dracula (1897).

\footnotetext{
*Resenha publicada em The London Times.

Disponível em : http://www.matrixtheatre.com/shows/stnicholas.html. Acesso em: 10/11/2009.
} 
Esta obra representa um ponto alto na tradição da ficção sobrenatural irlandesa, mas vampiros podem ser encontrados na literatura antes mesmo de Drácula.

Em O Vampiro antes de Drácula, Martha Argel e Humberto Moura Neto (2008) apresentam um longo histórico de aparições do vampiro na prosa, na poesia e no teatro e explicam que o conto do inglês John William Polidori (1795-1821), The Vampyre, publicado em 1819 pode ser considerado como o ponto de partida da prosa vampírica. Antes deste conto, só se conhecia o vampiro folclórico que era visto como um monstro repugnante com unhas compridas, barba malfeita, boca e olhos esbugalhados, rosto vermelho e inchado, sempre envolto em sua mortalha. Polidori criou o vampiro aristocrata, o nobre satânico, sedutor e elegante, um ser que convivia em sociedade, frequentava festas e viajava por diversos países escolhendo suas vítimas. Conta-se que Polidori usou como base de seu conto um fragmento de uma história sobrenatural escrita pelo poeta britânico Lord Byron. Em junho de 1816, uma tempestade prolongada manteve um grupo de amigos isolados numa casa alugada por Byron na Suíça. Deste grupo faziam parte além de Byron e Polidori - na época, secretário e médico particular de Byron - o também poeta Percy Bysshe Shelley, sua futura esposa, Mary Wollstonecraft Godwin, e a meia-irmã desta, Claire Clairmont. Para passar o tempo, eles liam em voz alta histórias sobrenaturais. Certa noite foi proposto que cada um escrevesse uma história de fantasmas. Percy Shelley começou um conto que não chegou a terminar e Claire parece não ter escrito nada. Já Mary, deu início a um conto que depois se transformaria no romance Frankenstein (1818). Polidori começou uma história sobre uma mulher que teve sua cabeça transformada em caveira depois de espiar por um buraco de fechadura, e Lord Byron escreveu o relato da morte repentina e inexplicável de um amigo chamado Augustus Darvell. Polidori apropriou-se desta narrativa e criou o vilão de seu conto Lord Ruthven à imagem e semelhança do poeta Byron. O conto foi um grande sucesso pois, por engano ou má-fé, foi publicado com autoria falsamente atribuída a Byron e, apesar dos protestos tanto de Byron como de Polidori, a história continuou por muito tempo sendo tratada como obra de Byron. Interessante observar que a partir de uma brincadeira entre amigos tenham sido criadas duas importantes obras da literatura sobre o sobrenatural: Frankenstein (1818), de Mary Shelley e o conto The Vampyre, que "estabeleceu de uma vez por todas o protótipo do vampiro na ficção, no teatro e posteriormente no cinema". (ARGEL \& MOURA NETO, 2008, p. 28). O vilão Lord Ruthven do conto de Polidori serviu de inspiração para outras obras, especialmente 
na França e na Inglaterra, entre elas, podemos mencionar uma adaptação para o teatro francês feita em 1820 por Charles Nodier - Le Vampire - que muito contribuiu para a popularização da figura do vampiro na época.

Por outro lado, na Irlanda, em 1872, segundo Peter Tremayne, em Irish Masters of Fantasy (1979), uma imagem mais inovadora para o vampiro foi apresentada pelo escritor irlandês de contos sobrenaturais, Sheridan Le Fanu (18141873), com o lançamento de seu conto Carmilla, que incorpora a crença em vampiros a um ambiente gótico. Na narrativa de Le Fanu uma série de mortes dizima as moças de uma região próxima do castelo onde vive a narradora Laura, depois que Carmilla passa a morar com ela. No decorrer da história percebe-se que Carmilla (anagrama de Mircalla) é a condessa Mircalla de Karnstein, morta há mais de um século e enterrada a meia légua do castelo. A vampira não suporta os cantos fúnebres e religiosos, não faz suas orações antes de dormir e, além disso, ela é capaz de sair de seu quarto sem abrir portas ou janelas. Como não come, ela é constantemente acometida de languidez, tem caninos pontiagudos e assume a forma de um gato monstruoso. Quando suga o sangue de uma pessoa deixa uma marca azulada e no momento em que o General Spielsdorf, cuja filha ela matou, ataca-a com um golpe de machado, ela desaparece numa névoa.

O renomado escritor irlandês Bram Stoker (1847-1912) inspirou-se também nos trabalhos de Polidori e Le Fanu para compor sua mais famosa personagem - 0 Conde Drácula - um predador aristocrático, saído do túmulo, que hipnotiza,corrompe e se alimenta do sangue de lindas moças. Entre as inovações, o vampiro Drácula tem a necessidade de repousar num caixão com solo nativo, não pode entrar nas casas sem ser convidado e sua imagem não se reflete em nenhum espelho. O romance foi publicado em 1897, no entanto Stoker escreveu o conto Dracula's Guest, publicado postumamente em 1914 por Florence Bram Stoker, numa coleção de contos intitulados Dracula's Guest and Other Weird Stories. No prefácio explica-se que tal conto havia sido suprimido do romance pelos editores, que acharam o manuscrito original muito extenso. Existem semelhanças entre Carmilla e essas obras de Stoker. Em Dracula's Guest surge um lobo muito estranho, que não parece ser um simples animal e na história de Le Fanu a heroína se vê frente a frente com um enorme gato, que mais parece um lobo. Já em Dracula, o vampirólogo Abraham Van Helsing, quando está ensinando a seus amigos tudo o que é preciso saber sobre os vampiros, esclarece que tal criatura precisa nutrir-se do sangue dos vivos, não se alimenta 
como os homens e possui uma força extraordinária, podendo transformar-se em lobo ou em morcego e quando se aproxima de alguém, geralmente está envolto numa bruma gerada por ele mesmo. O alho e a cruz de ouro são mencionados como objetos que tiram o poder do vampiro.

Bram Stoker faleceu em 1912, mas Drácula só alcançou fama no final da década 1920, em decorrência do sucesso de uma adaptação do romance para o teatro e posterior transposição para o cinema, com o filme Dracula (1931) da Universal Studios, dirigido por Tod Browning e com Bela Lugosi no papel do vampiro. Argel e Moura Neto (2008, p.307) explicam que houve alguns filmes anteriores baseados em Dracula. Embora um deles, o filme mudo alemão Nosferatu (1921), dirigido por F.W. Murnau seja considerado um clássico atualmente, nenhum deles teve grande impacto na disseminação da obra e do mito junto ao público. A aparência do ator Bela Lugosi, suas maneiras distintas e o sotaque húngaro fizeram com que seu desempenho fosse ao mesmo tempo assustador e memorável para a época. Segundo J. Gordon Melton, em O Livro dos Vampiros, o filme de Browning estabeleceu "a imagem visual do vampiro que se tornou padrão: uma figura aristocrática sinistra, de maneiras elegantes, sotaque estrangeiro e que se veste para a noite de maneira formal, com uma longa capa esvoaçante" (2003, p.13).

O sucesso cinematográfico atingiu as massas ao redor do mundo e permitiu que o vampiro invadisse nossas vidas através de todos os tipos de mídia que se desenvolveram nos séculos XX e XXI. Eles podem ser encontrados nas histórias em quadrinhos, em romances para adolescentes, desenhos animados, televisão, jogos de RPG, vídeo games e em diversos sites da Internet. Desde sua origem, o vampiro passou por muitas transformações: da figura monstruosa do folclore, passando pela figura do nobre do conto de Polidori que conquistou a Europa até a figura do conde Drácula que conquistou o mundo.

Em St Nicholas, poderíamos perguntar: que mudanças esse monólogo impôs à figura do vampiro? Além do mais, St Nicholas foi escrita em 1997, ano de comemoração do centenário do romance de Bram Stoker que suscitou eventos nos Estados Unidos, no Canadá, na Grã-Bretanha e na Irlanda; cada um desses países até lançou um selo comemorativo com Drácula. Estaria Conor McPherson parodiando a figura do vampiro em St Nicholas?

Segundo Linda Hutcheon, a paródia pode ser definida como a "inversão irônica, nem sempre às custas do texto parodiado", ou seja, é uma "repetição com 
distância crítica, que marca a diferença em vez da semelhança" (1985, p.17). Para Afonso Romano Sant'Anna, "a paródia é a inversão do significado e tem o seu exemplo máximo na apropriação, que se situa no conjunto das diferenças, com força crítica" (2004, p.48). Sant'Anna complementa que a paródia seria como um espelho invertido, ou mesmo uma lente: "exagera os detalhes de tal modo que pode converter uma parte do elemento focado num elemento dominante, invertendo, portanto, a parte pelo todo, como se faz na charge e na caricatura" (2004, p.32). Estamos, portanto, falando de um conceito que supõe distanciamento, inversão do sentido com efeito irônico e crítico.

O Dracula de Stoker foi o tema da Dissertação de Mestrado de Valdemar Francisco de Oliveira Filho - A Suspensão Momentânea da Ordem e Hierarquia em Dracula, de Bram Stoker (2005) - sob a orientação da Profa. Dra. Laura Patrícia Zuntini de Izarra, da Universidade de São Paulo. Neste trabalho, o autor sugere que podemos considerar a estada de Jonathan no castelo de Drácula como um ritual de iniciação necessário, um rito de passagem da inocência para a maturidade. Segundo Oliveira Filho, os ritos de passagem possuem uma estrutura trifásica - separação, iniciação e retorno. Primeiro há um período de separação, quando o iniciado deverá afastar-se do dia-a-dia e por algum tempo irá ser uma pessoa não-normal que vive num tempo não-normal. Geralmente o iniciado é mantido num espaço fechado e sem acesso às pessoas do seu convívio comum; submete-se a uma série de prescrições e de proibições que podem ser sobre comida, vestimenta e movimentos; quando termina este período, ele retornará à sociedade normal assumindo seu novo papel. Assim, Jonathan é isolado do convívio dos seres humanos normais, defronta-se com o mundo dos vampiros no castelo de Drácula, consegue escapar e retorna à sociedade com o conhecimento necessário para ajudar os caçadores a exterminarem o Conde Drácula. Ainda, segundo o autor, Drácula é o "doppelgänger"” de Jonathan, isto é, o conde Drácula seria o "outro" Jonathan, o seu duplo, conceito muito comum na literatura fantástica, como por exemplo, Dr. Jekyll e Mr. Hyde ou Dorian Gray e seu retrato. Esse outro representa um eu adorado e odiado ao mesmo tempo. É

\footnotetext{
* Doppelgänger, segundo as lendas germânicas de onde provém, é um monstro ou ser fantástico que tem o dom de representar uma cópia idêntica de uma pessoa que ele escolhe ou que passa a acompanhar. Ele imita em tudo a pessoa copiada, até mesmo suas características internas mais profundas. O nome Doppelgänger se originou da fusão das palavras alemãs doppel (significa duplo, réplica ou duplicata) e gänger (andante, ambulante ou aquele que vaga). Disponível em: $<$ http://pt.wikipedia.org/wiki/Doppelganger> Acesso em: 22/11/2008.
} 
Drácula, o "outro" Jonathan, que se liberta, e livre, prepara-se para trazer o caos à vida de Jonathan.

Logo percebemos a semelhança entre o rito de passagem de Jonathan em Dracula com os acontecimentos relatados em St Nicholas; ao afastar-se do seu dia-adia em Dublin, indo para Londres e convivendo com o mundo dos vampiros um determinado tempo, o protagonista escapa e, transformado, volta a conviver em sociedade. Há, porém, muitas diferenças entre o narrador de St Nicholas e a personagem do romance de Stoker. Jonathan é um rapaz jovem, solteiro que viaja a trabalho, para levar os papéis da propriedade que Drácula adquiriu em Londres para serem assinados. O protagonista de St Nicholas é um homem de quase sessenta anos, casado, com dois filhos, que abandona emprego e família para ir à Londres em busca de uma paixão por uma jovem atriz. No início era egoísta, não se comunicava bem com a família, bebia muito e não produzia nada importante. Embora tivesse grande habilidade de conectar as palavras, não tinha ideias para escrever suas próprias histórias, só se limitava a criticar o trabalho de outros. Ao sair da casa do vampiro, terá uma segunda chance de retomar sua vida com esposa e filhos e finalmente terá uma história para ser contada. O protagonista-crítico não é um herói dos contos góticos e da era vitoriana, mas sim o "herói" do nosso mundo, dos dias de hoje. Mora numa casa confortável na melhor área de Dublin; sua esposa está fora de forma e, assim como ele, bebe muito; sua filha está na faculdade e parece gostar de escrever contos e poemas e seu filho não faz nada - é sustentado pelo pai. Portanto, esse narrador é um típico homem de meia-idade bem sucedido financeiramente, mas infeliz com sua própria vida e as relações que o cercam. A vida que levava antes do convívio com os vampiros não tinha muito sentido para ele; o final da peça sugere um estilo de vida melhor. O rito de passagem de Jonathan em Dracula marca a mudança da adolescência para a vida adulta; para o crítico o rito de passagem é diferente, não está somente ligado à idade, mas também à maneira como ele encara o mundo e o legado que irá deixar. No início de seu monólogo, ele explica que podia sentir que o tempo estava passando e ele não havia feito nada ainda - as mesmas ansiedades que acometem o homem contemporâneo.

A epígrafe deste capítulo reproduz o início da resenha de St Nicholas que Ben Brantley escreveu para o New York Times, sugerindo que, embora o protagonista tenha dividido sua vida em antes e depois do convívio com os vampiros, na verdade ele já seria uma espécie de vampiro, mesmo antes de ter tido contato com eles. 
Quando o narrador entra em contato com o mundo do vampiro William, ele percebe no vampiro, no outro, aquilo que ele mesmo não quer ser. As mesmas críticas que ele faz ao vampiro são os aspectos negativos de sua própria personalidade. Lembramos aqui que assim como Drácula é o "doppelgänger" de Jonathan, William seria o duplo do protagonista. O crítico de teatro se alimenta da arte dos outros da mesma maneira que o vampiro se nutre do sangue alheio; afinal, sangue e arte são símbolos da vida. Além disso, ele também gosta do poder que exerce sobre os artistas através do medo, uma vez que uma crítica ruim poderá arrasar qualquer carreira. Estamos diante de uma metáfora, o protagonista-crítico é visto como um vampiro e quando ele percebe que os vampiros são seres sem consciência, ele próprio toma consciência de como deve agir, "voltar a ter contato com as coisas" (p.177). Entende que durante a vida toda foi um ser que afastava as pessoas e viveu como um vampiro; porém, agora ele quer o poder de "tocar" as pessoas. Este poder irá se concretizar na história a ser contada.

Observamos que o título da peça - St Nicholas - faz alusão ao Bispo de Myra, no sul da Turquia, também conhecido por Santa Claus, e famoso por sua piedade perante os menos favorecidos, protegendo e presenteando sempre as crianças e também praticando a castidade. Nenhuma semelhança com o nosso protagonista. Ao escolher tal título McPherson estaria usando de ironia. Segundo Douglas Colin Muecke, em Ironia e o Irônico a definição de ironia não é "dizer uma coisa e dar entender o contrário", mas sim "dizer alguma coisa de uma forma que ative não uma, mas uma série infindável de interpretações subversivas" (1995, p.48). Além de o narrador ser o oposto do Bispo de Myra em termos de personalidade, St Nicholas também é uma alusão ao Natal, tempo de recomeço, exatamente o que poderá acontecer depois que o protagonista-crítico consegue escapar dos vampiros. Notamos também que antes de ter trabalhado para os vampiros ele se sentia como o "protetor das massas contra os artistas charlatães que tentavam roubar o dinheiro do povo" (p.138)*. Mais uma irônica referência ao Bispo que protegia os menos favorecidos. Enquanto o narrador convive com os vampiros, ele tenta escrever sobre os momentos em que ele se importava com os seus e lembra-se dos filhos pequenos na véspera do Natal. Percebe-se que o Natal é uma imagem recorrente na peça. Além de St Nicholas, McPherson faz referências ao Natal em duas outras peças:

\footnotetext{
* Todas as citações de St Nicholas são desta edição: McPHERSON, Conor. McPherson: Four Plays London: Nick Hern Books, 1999.
} 
Dublin Carol (2000) e The Seafarer (2006) que são ambientadas na véspera do Natal, data que simboliza o renascimento e a esperança de uma nova oportunidade, com novos sonhos e perspectiva de harmonia entre os homens. The Seafarer será discutida no terceiro capítulo.

Nota-se que, em St Nicholas, o dramaturgo faz uso de ironia para construir essa personagem que retrata as ansiedades e preocupações do homem contemporâneo e, ao invés de contar a história desse crítico de teatro de forma realista, McPherson utiliza-se do sobrenatural, mais precisamente da figura do vampiro. Uma vez que o conceito de paródia sugere inversão do sentido com efeito irônico e distanciamento crítico, temos que observar quais os desvios entre St Nicholas e as histórias tradicionais de vampiros.

Na primeira parte da peça, na noite em que o protagonista-crítico oferece uma carona para Helen, aparecem os primeiros indícios de elementos do sobrenatural.

\section{I couldn't sleep.}

I sat in my study with the windows open. That summer breeze.

And I thought about killing myself. I could imagine the cast reading the review l'd actually given them, talking about what a complete cunt I was. And then they'd find out I was dead and they'd feel rotten. That they hadn't taken into account the integrity you know? The mystery that I was. But I was too chicken for that.

Instead I lay on the sofa and things crawled all over me till it got bright.

Well, I wasn't the same after that.

Através desse excerto, observamos que o protagonista já teria tido contato com "coisas estranhas" que poderiam ter entrado pela janela aberta, como Drácula, que em forma de morcego, adentra pela janela do quarto de Lucy. Além disso, o narrador menciona que as mãos de Helen estavam geladas quando eles se despediram, fato que também pode ser associado com mortos e vampiros. Percebemos que os elementos sobrenaturais presentes na primeira parte da peça funcionam como indícios do que o narrador encontrará na segunda parte. Como se McPherson preparasse o leitor para a possibilidade do convívio do crítico com os vampiros e ao mesmo tempo oferecesse uma hipótese para explicar o sobrenatural a de que o protagonista estivesse apenas sonhando. 
Outro aspecto interessante é a maneira como William aproximou-se pela primeira vez do protagonista, bem semelhante à aparição dos vampiros estudados nos contos já mencionados e em Dracula: ele estava num parque isolado, já havia escurecido e teve a impressão de ter visto um cachorro bem grande. "Eu vi algo se movendo, pensei que fosse um cachorro grande... Era um homem" (p.156). E mais adiante é mencionado que, embora estivesse escuro, ele conseguia ver os olhos de William brilhantes como os de um gato. O vampiro possuía, portanto, características de animais como as do lobo, do cachorro e do gato, os mesmos animais citados nos contos Carmilla e Dracula's Guest, bem como no romance de Stoker. Para explicar como são os vampiros, o narrador fala do poder que eles têm de fazer com que as pessoas queiram o mesmo que eles. E quando está na presença deles, ele não é capaz de ponderar sobre um assunto, de usar a razão, vive mais por instinto. Os vampiros teriam então o poder de afastar o protagonista da razão e fazê-lo conviver por algum tempo no mundo dos instintos, à semelhança dos animais irracionais. Tal convivência fará com que o protagonista-crítico reveja sua maneira de encarar a vida e seus relacionamentos.

A casa de William poderia ser descrita como uma velha casa gótica, ou seria uma alusão ao interior do castelo de Drácula; "Pilares imponentes. Árvores altas... Nas paredes, painéis feitos de madeira escura. Carpetes de um vermelho bem vivo". (p.158). A cor vermelha sugere o sangue; ao invés de caixões individuais para os vampiros dormirem, a casa é revestida de madeira, como se fosse um grande caixão. O narrador também se refere à cozinha como sendo confortável e aquecida, mas observa que não se via nenhuma comida, provando que os vampiros não se alimentam como os homens. Tal fato nos faz lembrar que Drácula oferecia jantares para Jonathan só que ele mesmo nunca comia. Além do mais, no castelo de Drácula, Jonathan encontra um trio de vampiras e o vampiro William convive com seis mulheres também vampiras. Nos dois casos, elas são instruídas a não perturbarem os hóspedes e nas duas histórias essas regras são quebradas. No romance de Stoker, certa noite, as vampiras invadem o quarto de Jonathan que, sem forças para reagir, precisa ser salvo por Drácula, que aparece no momento crucial, expulsandoas do aposento. No caso de St Nicholas, uma das mulheres consegue subjugar o narrador que acaba se entregando e acorda com a camisa e as calças ensanguentadas. "Havia sangue na minha camisa. Nas minhas calças. Meu único consolo é que ela iria ficar com uma tremenda ressaca, que a derrubaria por dias. Ela 
havia mordido o homem errado" (p.175). Como se vê, Conor McPherson usa do humor para descrever praticamente a mesma cena de heroísmo em Drácula. Além disso, como o protagonista estava bêbado, seria bem provável que ele estivesse imaginando ou tendo alucinações. No início da segunda parte da peça, quando William está mostrando a casa, o narrador chega a mencionar que queria acreditar que ainda estivesse sonhando*. Outra vez temos a hipótese do sonho como provável explicação para o sobrenatural.

O humor também é usado para salientar outras diferenças entre William e os outros vampiros literários. O alho, por exemplo, não tira seu poder - ele só não gosta porque dá mau-hálito. Acreditamos que este aspecto foi citado na peça para tornar William um vampiro mais próximo do homem contemporâneo, preocupado com a aparência. Nada é mencionado com relação a crucifixos, outro modo de afastar os vampiros, mas o narrador encontra em seu quarto uma Bíblia e indaga se o vampiro não se importa com tal livro. William responde: "A natureza fez ambos" (p.159). O que nos leva a crer que William não se abala com os símbolos do cristianismo. Comentando sobre o que o afeta, William fala de uma tradição no leste da Europa de colocar arroz no parapeito das janelas para afastar os vampiros ${ }^{\dagger}$. Dizem que arroz também simboliza fertilidade, fartura e prosperidade. Os vampiros seriam compelidos a contar todos os grãos de arroz até o amanhecer. Para William esta lenda tem um fundo de verdade porque ele teria um "desejo incontrolável de saber quantos grãos há em um punhado de arroz" (p.160). O interessante é o protagonista-crítico observar que o vampiro achava que isso era um traço de sua nobreza e não uma compulsão, "ele transformava seus defeitos em virtudes" (p.160). É graças a esta compulsão que o protagonista consegue escapar da casa de William. A forma como Jonathan escapa do castelo de Drácula, correndo pelos corredores sombrios, fugindo das três vampiras e descendo pela torre do castelo, difere da maneira cômica pela qual o narrador escapa da casa de William, "eu disse para deixá-la em paz e juro por Deus que os olhos dele brilhavam feito fogo... Então, ajudei Helen a descer as escadas.

\footnotetext{
* "I wanted to believe I was still dreaming" p.158

${ }^{\dagger}$ Nossa pesquisa nos levou a uma lenda semelhante: "In parts of the West Indies, country folk believe that they can protect themselves against a supernatural being that drinks blood by sprinkling grains of rice close to windows and doors. The legend goes that before the creature can attack it must pick up every grain - by that time it should be dawn and, as everybody knows, by cock-crow, all vampires must return to the safety of their lair."

Disponível em: http://www.lastrefuge.co.uk/data/articles/bats/Vampire Bat article page1.html Acesso em: 22/11/2008.
} 
Ele não nos seguiu e não sei por que me deixou ir embora" (p.177). Ele acaba não levando Helen, e deixa-a dormindo no sofá da sala ao lado de um dos amigos dela, que também acordará de ressaca. Portanto, o poder que o vampiro teria sobre ele foi facilmente quebrado, sem grandes lutas como as dos heróis dos romances góticos.

Outra hipótese para explicar o sobrenatural seria a possibilidade de o protagonista ter passado por um colapso nervoso; ele próprio refere-se a esta probabilidade quando está saindo da casa do vampiro: "Eu andei pela rua pensando no que as pessoas iriam dizer... Voltando de meu colapso" (p.177). Neste sentido, a história que está sendo contada no palco não seria bem o que "aconteceu" realmente, o narrador poderia ter imaginado tudo. Mas este período de sua vida e a suposta convivência com os vampiros foi crucial para sua transformação.

O fato de sabermos mais sobre as personagens envolvidas com a época em que ele convive no mundo dos vampiros em Londres do que sua vida em Dublin, já demonstra a importância desta época para o narrador. Praticamente conhecemos os nomes da maioria das personagens da história: o vampiro chama-se William, Helen a atriz, o diretor da peça Peter Hamilton, as outras atrizes amigas de Helen chamam-se Cliona Leeson e Sheila Kilmeady e uma das vítimas de William é Dominique. Entretanto, não sabemos o nome do protagonista e nem de sua esposa e filhos. Ao que parece, só as personagens que fazem parte da história relacionada aos vampiros são nomeadas e não as pessoas que fazem parte da vida "real" do protagonista. Talvez uma maneira de Conor McPherson destacar a importância da história que está sendo narrada no palco. Vale lembrar que quando o narrador fala de seu passado como crítico, marido e pai, as lembranças são sempre aleatórias e não lineares - fatos que veem à memória do protagonista de forma desordenada; já os acontecimentos depois do encontro com William são relatados de forma linear, mesclando ações e emoções; aspectos importantes ao se contar uma história, o que demonstra uma organização literária.

A importância de se ter uma história também pode explicar o fato de a peça ter sido escrita em forma de monólogo. Conor McPherson começou a escrever monólogos em 1992, apesar de ter usado o diálogo em algumas peças anteriores, essas não foram publicadas. St Nicholas, seu quarto monólogo, foi escrito e encenado na década de 90, época em que, segundo Eamonn Jordan (2006, p.125), os monólogos tornaram-se uma característica importante no drama irlandês. Jordan explica que enquanto no teatro internacional havia a preocupação com produções 
estilizadas e em grande escala, no teatro irlandês houve uma proliferação de peças em forma de monólogos, escritas principalmente por homens para personagens masculinas, geralmente um único ator no palco, sem recursos cênicos, simplesmente contando uma história. Os quatro primeiros monólogos de Conor McPherson têm essas mesmas características: atores num palco vazio narrando histórias diretamente para os espectadores. Como em St Nicholas, nas peças Rum and Vodka (1992) e The Good Thief (1994) há somente um ator no palco relatando suas desventuras para a platéia. Em This Lime Tree Bower (1995), embora as três personagens masculinas estejam presentes ao mesmo tempo no palco, não há quase nenhuma interação entre elas e seus monólogos visam claramente à platéia como ouvinte.

Com o objetivo de descobrir qual a função e o efeito do monólogo em St Nicholas, seria importante verificar a diferença dos termos monólogo, solilóquio e aparte. À primeira vista, monólogo e solilóquio parecem ser sinônimos perfeitos e, se analisarmos as palavras etimologicamente, veremos a equivalência dos dois vocábulos: monos corresponde a solus, que seria único, sozinho, e logos corresponde a loqui, palavra, discurso, falar. Os termos, então poderiam ser definidos como falar só. No Dicionário de Termos Literários, Massaud Moisés (2004, p. 431) confirma a equivalência etimológica dos dois vocábulos e comenta que o "solilóquio é, acima de tudo, uma convenção teatral... consiste na situação em que a personagem está sozinha no palco e profere em voz alta os seus pensamentos: fala para si própria, de modo a tornar-se sujeito e objeto da ação verbal." Para Moisés, o monólogo é uma peça de teatro em torno de uma só figura, como o Monólogo do Vaqueiro (1502) de Gil Vicente, e difere de um terceiro termo - monólogo dramático (Dramatic Monologue) - que consiste num poema destinado à declamação e que revela dramas internos da personagem, ou do "eu poético"; citando como exemplo My Last Duchess, de Robert Browning. Já o aparte - também uma convenção teatral seria o recurso em que a personagem manifesta brevemente seus pensamentos em voz baixa, geralmente contrários aos que são transmitidos ao seu interlocutor, de tal forma que só a platéia ouça - transformando-a em confidente. No aparte, outras personagens também podem estar presentes no palco; o ator que o profere na maioria das vezes afasta-se dos demais e muda de entonação. Já Patrice Pavis (1999, p. 247 e 366), em seu Dicionário de Teatro, define tanto monólogo quanto solilóquio como sendo "um discurso que a personagem faz para si mesma" e a peça como monólogo seria somente um dos tipos de monólogo. Outro tipo de monólogo 
citado com freqüência é o Interior Monologue, ou monólogo interior, que segundo Pavis (1999, p.248) são fragmentos de frases que passam pela cabeça do recitante e são emitidas sem preocupação com lógica ou censura; pois o efeito desejado é o da desordem emocional e cognitiva da consciência que mostra o que ocorre na mente da personagem. Como exemplo do uso do monólogo interior no teatro, Peter Szondi (2001, p.155) menciona a peça Estranho Interlúdio (1928), "drama de nove atos de Eugene O'Neill, [que] não esboça apenas os diálogos de seus oito heróis, mas também, e continuamente, seus pensamentos íntimos..." Esse tipo de monólogo é mais comum na prosa e muitos estudiosos ressaltam sua ligação com o conceito de fluxo da consciência - stream of consciousness. Segundo Massaud Moisés (2004) fluxo da consciência é um conceito de natureza psicológica, que nomeia os múltiplos aspectos da atividade mental, enquanto que o monólogo interior seria uma técnica literária, de apreensão e apresentação do fluxo da consciência.

Um dos trabalhos mais completos que encontramos sobre o monólogo teatral foi a Tese de Doutorado de Alcides João de Barros apresentada à Escola de Comunicações e Artes da Universidade de São Paulo em 1985 sob a orientação da Profa. Dra. Célia Berrettini. Nesse trabalho, foi ressaltada a dificuldade de se chegar a um consenso sobre a definição de monólogo e solilóquio. Barros explica que em português usamos o vocábulo monólogo para indicar tanto uma peça de um só ator, quanto para designar cenas grandes em que a personagem fala consigo mesma, que poderiam ser classificadas como solilóquios também. O autor decidiu usar o termo monólogo para "designar toda e qualquer passagem em que uma personagem fala consigo mesma, embora o público seja o receptor obrigatório." (BARROS, 1985, p. 30) Tal definição será adotada neste trabalho. Quanto ao termo aparte, indicará aquelas falas rápidas, ditas na presença de uma ou mais personagens, mas ouvidas convencionalmente somente pelos espectadores. No decorrer da pesquisa observamos que Conor McPherson possui peças inteiras em forma de monólogo onde um ou mais atores relatam suas histórias diretamente para a platéia e que também faz uso de monólogos em peças onde o diálogo é predominante.

Já de posse de uma definição de monólogo, procuramos definir quais as suas funções essenciais no teatro. Barros estabelece uma classificação fundada com base no teatro greco-latino, que poderá contribuir para nossa análise. Ele elucida que o monólogo de exposição pode ocorrer no início ou durante a peça, e sua função é fornecer ao público dados sobre a ação que irá acontecer no palco, características 
das personagens e acontecimentos anteriores que o espectador deve conhecer para melhor acompanhar a ação. Por outro lado, o monólogo de anúncio explica acontecimentos futuros que ocorrerão dentro ou fora do palco. Outra categoria é o monólogo de comentário que explana uma ação que já ocorreu, normalmente com o uso de ironia. Esse tipo de monólogo permite a interferência do autor que, através de uma personagem, expõe sua ideologia. Há ainda o monólogo de deliberação que informa sobre o rumo que uma personagem deve seguir. Este tipo é bastante próximo do monólogo de anúncio. Já o monólogo de caracterização tem a função de caracterizar o locutor/personagem. O monólogo de moralização seria um comentário edificante a respeito de alguma passagem da peça e, finalmente, o monólogo de comicidade que explora as confusões criadas no palco com o objetivo de fazer o público rir.

Sem desconsiderar os sete tipos de monólogos apresentados acima, Barros também propõe uma classificação diferente, baseada em certas características que gerariam dois tipos fundamentais de monólogos - o autêntico e o convencional. $O$ monólogo autêntico caracteriza-se pelo seu conteúdo poético, revela os sentimentos da personagem, é subjetivo, presta-se à expressão do fluxo da consciência e interrompe a ação da peça. Semelhante a um poema, não gera reações a respeito de sua verossimilhança e tem por função acentuar o conteúdo dramático, enriquecendo a peça. Já o monólogo convencional não possui conteúdo poético, a personagem comenta algum aspecto da peça ou fornece informações objetivas que ajudarão o espectador a acompanhar a ação. É esse monólogo que costuma ser rejeitado como artificial e inverossímil e pode acrescentar muito pouco ao valor estético da peça.

Quais as semelhanças e diferenças na função do monólogo entre peças de diversas épocas ao longo da história do teatro e St Nicholas? Nesta pesquisa, a tese de Alcides João de Barros (1985) também se mostrou bastante significativa porque traz um panorama do monólogo desde o teatro grego até o teatro no século $X X$ e mostra-nos que tanto no teatro grego quanto no teatro romano já existiam monólogos nas tragédias e nas comédias. Segundo Barros, na tragédia grega, a presença do monólogo está ligada ao coro e, como não há lugar para a linguagem corriqueira do cotidiano, tais passagens eram essencialmente líricas. Muitas vezes os prólogos das tragédias assumiam a função de monólogos de exposição e, por seu teor poético, podiam ser chamados de monólogos autênticos. Já nas comédias observa-se o domínio do monólogo convencional; no entanto, há alguns monólogos em linguagem 
solene que, isolados de seu contexto, poderiam funcionar como monólogos autênticos. Como exemplo, na comédia grega As Aves, de Aristófanes, quando o corifeu se dirige ao público para falar sobre as vantagens de ter asas, tais comentários podem levar o espectador à reflexão, à crítica e certamente interrompem a ação. No teatro romano, as tragédias de Sêneca possuem grande quantidade de monólogos pelo fato de ser um teatro destinado à leitura, não à representação.

No período medieval, continua Barros, os monólogos são bastante numerosos, tanto no teatro religioso quanto no profano. No teatro religioso, apresentado dentro da própria igreja, há exemplos de monólogos poéticos e solenes. Já no profano, um teatro mais popular, encontramos mais monólogos convencionais, paródias de sermões sobre tipos sociais e políticos e sobre superstições. Nessa época, os monólogos assumiam um caráter de pregação, como se fossem um sermão vindo do púlpito. Nas peças de Gil Vicente podem ser encontrados exemplos de monólogos convencionais e autênticos, mas quase sempre com a função de pregação. Nessas peças, anjo e diabo falam alternadamente, mas sem dialogar, dirigindo-se à platéia com monólogos em forma de oração. É interessante observar que nesse período apareceram várias peças em forma de monólogos, de caráter cômico-satírico.

Nos séculos XVI e XVII, ainda segundo Barros, o teatro recupera a grandeza alcançada no teatro grego com alguns dramaturgos importantes: na Espanha, Cervantes, Calderón e Lope de Vega; na Inglaterra, Shakespeare e na França, Pierre Corneille, Racine e Molière. O teatro dessa época não é voltado só à religião e nem é essencialmente popular, mas o monólogo continua bem presente. $\mathrm{Na}$ tragédia, monólogos autênticos servem para embelezar e elevar o nível artístico da peça. Um exemplo mencionado com frequência é o monólogo de Hamlet, "ser ou não ser". No entanto, os monólogos convencionais, mais numerosos que os autênticos, são empregados tanto nas tragédias quanto nas comédias e, na maioria das vezes, com a função de facilitar a elaboração da peça e não de melhorar a qualidade da obra.

Quanto aos dramaturgos do século XVIII, continuam empregando monólogos na mesma proporção e com as mesmas funções dos autores do período anterior. Entretanto, surge nesse período outra função, o monólogo de protesto contra as autoridades. Em O Casamento de Fígaro, de Pierre de Beaumarchais (1732-1799), por exemplo, sob o pretexto de comentar o desenrolar da ação, a personagem ironiza a arrogância e os privilégios da classe dominante francesa. No caso, o monólogo torna-se um meio de propagar as idéias revolucionárias do autor. 
No século XIX, o teatro também é influenciado por importantes movimentos artísticos como o Romantismo, o Realismo e o Naturalismo. Victor Hugo, o principal teórico do romantismo, propunha que a ação deveria ser mostrada ao público e não narrada como na tragédia clássica. Contudo, no teatro romântico, os monólogos convencionais e até mesmo os apartes, embora condenados, não desaparecem de cena e os monólogos autênticos adquirem a função de mostrar o interior das personagens, ou melhor, seus pensamentos.

Por ser considerado artificial e inverossímil, o monólogo foi praticamente abolido do teatro naturalista. No entanto, reapareceram as peças de uma única personagem, encontradas na Idade Média. Um exemplo interessante é a peça de Tchekhov, Os Malefícios do Tabaco, na qual o dramaturgo contorna o problema da verossimilhança dando à peça o formato de uma conferência. Muitos desses monólogos representavam a negação da vida. Já no século $X X$, multiplicam-se as peças de uma única personagem, mostrando que o ser humano está solitário. Em muitas dessas peças, percebe-se certo negativismo que irá levar ao aniquilamento da personagem. Samuel Beckett, por exemplo, escreve Solo (1979), fragmentos de uma história sobre nascimento, morte e principalmente solidão e Cadeira de Balanço (1980), onde uma mulher escuta a gravação de sua própria voz enquanto se despede da vida sentada na mesma cadeira em que sua mãe morreu. Alguns dramaturgos passam a usar o monólogo amplamente e agora com a função de desfazer a ilusão da "quarta parede", precisamente para lembrar ao público que o teatro é uma convenção, isto é, manter o espectador consciente de que o teatro é uma representação dos problemas da vida, da realidade, e que precisamos estar alertas e críticos. Para Brecht, o monólogo torna-se um dos meios de afastar a ilusão que a representação possa causar, cria um distanciamento. Em A Alma Boa de Setsuan (1943), por exemplo, existem vários monólogos e momentos em que os atores falam diretamente com a platéia, com a intenção de fazer o público não esquecer que está no teatro.

Jean-Pierre Ryngaert comentando sobre o diálogo e o monólogo, menciona Pirandello e lembra que "por uma convenção tácita, admite-se no teatro que todo o discurso das personagens é ação falada, ou, em outros termos, que falar é fazer" (1996, p.103). Portanto a fala é ação, o próprio fato de falar constitui a ação da peça. Exatamente o que presenciamos no monólogo St Nicholas, nada acontece diretamente no palco, entretanto a fala da personagem está repleta de ação. Ainda 
assim, St Nicholas estaria mais próximo de um monólogo autêntico, pois, revela os sentimentos do protagonista praticamente o tempo inteiro; contudo não interrompe a ação uma vez que a fala constitui a própria ação nesta peça. A nosso ver, St Nicholas não simula a negação da vida, como nos monólogos de Beckett, mas sim um período de turbulência na vida do protagonista que o faz rever seus conceitos e sua posição frente aos caminhos tomados até aquele momento e querer retomar sua própria vida de outra maneira. "Voltando de um colapso nervoso. Tomando contato com as coisas. Falando Com Minha Esposa. Dando Conselhos Aos Meus Filhos"” (p.177). Interessante notar as letras maiúsculas nestas frases, como se tratassem de títulos para novas histórias, afinal, ter uma história é essencial para a personagem. "Eu tinha minha saúde. Eu tinha solução. Mas, acima de tudo, o mais importante. Eu tinha uma história" ${ }^{\dagger}$ (p.177). Possivelmente, para criar o mesmo efeito no palco, imaginamos que o narrador teria que fazer gestos indicando manchetes de jornal, pois não há nenhuma rubrica que mencione gestos para o narrador durante a peça inteira. Segundo Clare Wallace, em seu livro Suspect Cultures, McPherson privilegia os elementos linguísticos e não os visuais, "as palavras é que devem fazer o trabalho e não o espetáculo do cenário ou as ações das personagens" (2006b, p.59).

Embora St Nicholas não tenha a função de um monólogo de protesto, o fato de Conor McPherson ter escolhido um crítico de teatro para contar sua história, ao invés de um ator ou mesmo outro profissional ligado ao teatro, não deixa de ser uma crítica à atuação desse profissional, que como um vampiro, precisa do outro para sobreviver. Para escrever seu texto, o crítico precisa sugar a arte do outro.

Além da questão histórica relatada por Barros, observamos que o uso do monólogo no teatro irlandês tem características próprias, como se pode verificar no livro também editado por Clare Wallace (2006a), Monologues: Theatre, Performance, Subjectivity. Na introdução deste livro, Wallace confirma a dificuldade de se chegar a uma definição precisa para monólogo e compara a busca por tal definição à abertura da caixa de Pandora, pois as diferentes definições, muitas vezes, até se contradizem. Wallace ressalta que a ideia do livro surgiu da observação da proliferação de monólogos, principalmente no teatro britânico e irlandês do fim do século $X X$, tanto no teatro dito convencional quanto no alternativo que, por sua vez, levantou questões

\footnotetext{
* "Back from my breakdown. ... Getting back in touch with things. Talking To My Wife. Giving My Children My Advice." (p.177)

† "I had my health. I had resolve. But most important. Over everything else. I had a story." (p.177)
} 
ligadas à natureza do próprio teatro, da execução de tais peças e da recepção do público. O artigo de Eamonn Jordan intitulado "Look Who's Talking, Too: The Duplicitous Myth of Naïve Narrative" é um dos mais interessantes para nosso trabalho, pois transcorre sobre os tipos de monólogos no teatro irlandês, observa os temas mais recorrentes, exemplifica muitas vezes com peças de Conor McPherson, entre outros dramaturgos, e analisa algumas razões da abundância de monólogos neste período.

Jordan classifica os monólogos deste período - fim dos anos 80 e década de 90 - em quatro grupos distintos. Do primeiro grupo fariam parte os monólogos de um só ator relatando uma história no palco praticamente vazio, sem nenhum recurso cênico além da luz que indicaria o início e fim do espetáculo. Além de St Nicholas, Rum and Vodka (1992) e The Good Thief (1994) também são exemplos de monólogos deste grupo, pois nas três peças os narradores estão conscientes de estarem no palco, relatando suas histórias para um grupo de pessoas - os espectadores.

No segundo grupo também há um só ator no palco, só que desta vez ele interpreta mais de uma personagem, usando objetos ou o próprio espaço do palco para a marcação das personificações das diversas personagens. Como exemplo deste grupo Eamonn Jordan cita A Night in November (1994) de Marie Jones e Hurricane (2002) de Richard Dormer, sobre a vida de um campeão de sinuca Alex "Hurricane" Higgins.

O terceiro grupo é caracterizado pela presença de dois ou mais atores no palco, relatando suas versões sobre uma mesma história, podendo ou não haver interação entre as personagens. O precursor deste tipo de monólogo no teatro irlandês é Brian Friel com Faith Healer (1979) e Molly Sweeney (1994). Em Faith Healer, o curandeiro Frank Hardy, sua esposa/amante Grace e seu agente Teddy refletem sobre a habilidade de cura de Frank e relatam as alegrias e tristezas que Frank deixou em suas vidas. Não há nenhuma interação entre as personagens e seus relatos são tão contraditórios que ao final o leitor ou o espectador fica sem saber em quem acreditar. Já em Molly Sweeney, Molly, cega desde a infância, seu marido Frank e seu médico Mr Rice se alternam para relatar a história de como Molly teve a chance de fazer uma cirurgia que recuperaria sua visão que resultou em alterações em sua personalidade e em sua vida depois de voltar a enxergar. Tampouco há muita interação entre as três personagens em Molly Sweeney. Eden 
(2001) de Eugene O'Brien, que teve sua primeira montagem dirigida por Conor McPherson, também pode ser incluída neste grupo. Durante um fim de semana, um casal, Billy e Brenda, se alternam para relatar as diferentes perspectivas do relacionamento deles.

Quanto a McPherson, nota-se em This Lime Tree Bower (1995) uma estrutura bastante semelhante às peças de Friel acima citadas. Em monólogos alternados, Joe, Frank e Ray contam como se envolveram em um roubo. Durante a peça inteira não há interação entre os narradores que permanecem o tempo todo no palco, com exceção de uma fala trocada entre Frank e Ray. Outro exemplo de McPherson seria Come on Over (2001), peça curta de um só ato em monólogos alternados entre o padre jesuíta Matthew e Margaret, sua namorada na juventude. Nessa peça, dois atores, sentados e encapuzados com sacos de papel, falam diretamente com o público, porém, no fim da peça, Margaret retira o saco da cabeça, levanta-se e abraça Matthew.

O quarto e último grupo também envolve dois ou mais atores no palco, mas agora com narrativas distintas que possuem uma ligação tênue ou quase nada em comum. O exemplo mais significativo deste grupo seria Port Authority (2001), de Conor McPherson, com três narradores - Kevin, Dermot e Joe - com vinte, trinta e cinco e setenta anos respectivamente, que contam três histórias de vida diferentes, tendo em comum o fato dos três mencionarem a falta de coragem para agir diante de momentos decisivos de suas vidas, relacionados com amores perdidos e oportunidades de emprego. Eamonn Jordan também exemplifica este grupo com a peça We Ourselves (2000), de Paul Mercier sobre a vida de sete irlandeses que haviam trabalhado juntos numa fábrica na Alemanha.

Entre as explicações e teorias acerca da razão desta invasão de monólogos neste período, Jordan menciona o fato de os monólogos representarem baixo risco financeiro, pois geralmente estas peças envolvem poucos atores, quase nenhum custo com figurino e cenário e certamente uma maior facilidade de sair em turnê, tanto dentro quanto fora da Irlanda. Lembrando que apesar dos três primeiros monólogos de Conor McPherson terem sido encenados primeiramente em Dublin, foi em Londres que o dramaturgo obteve uma maior receptividade, passando a montar suas peças posteriores inicialmente em Londres e Nova York e só então em Dublin. Outra razão mencionada por Eamonn Jordan seria o fato de a Irlanda, como um país de tradição católica, ter no sacramento da confissão inspiração para as narrativas no 
palco que, acaba por se tornar, um grande confessionário; o contar histórias seria equivalente ao relatar os pecados antes de receber a absolvição. Nos monólogos de McPherson, Rum and Vodka (1992) e The Good Thief (1994), os narradores parecem mesmo buscar absolvição de seus pecados. Jordan também observa que o aumento de peças em forma de monólogos coincide com o surgimento do chamado Celtic Tiger, quando o individualismo, independência e foco em si mesmo (self-focus) foram qualidades muito mais valorizadas. Mas acima de tudo, para Jordan, monólogos e histórias estão entrelaçados e "most monologues are about making a story stick" (JORDAN, 2006, p.153).

A história para McPherson é a peça. Assim, quando o dramaturgo está dirigindo seus trabalhos, pede aos atores para nela acreditarem. $O$ autor traz ao palco homens perdidos, desesperados, precisando dividir suas vidas com os espectadores. A crise da masculinidade e a luta constante para estabelecer um senso de dignidade mesmo nas situações mais adversas são tópicos recorrentes nos monólogos de McPherson e de outros dramaturgos do mesmo período.

Hans-Thies Lehmann ressalta que um "traço essencial do teatro pós-dramático é o princípio da narração: o teatro se torna o lugar de um ato de contar" (2007, p.185). Neste sentido, podemos dizer que o teatro de Conor McPherson tem pelo menos um dos traços do teatro dito pós-dramático; pois, especialmente em seus monólogos, a história se torna o mais importante e o fato de contá-la no palco constitui um tipo de redenção para a personagem. Tal importância pode ser vista durante toda a peça. A primeira frase, "quando eu era menino, eu tinha medo do escuro", é semelhante ao "Era uma vez...", portanto podemos entender tal frase como o iniciar de uma história. Sabemos que o ator está só no palco e que se dirige diretamente ao público, não está falando consigo mesmo e no final até questiona a platéia sobre a verdade ou não de sua história, "Então, eles eram reais? Ou não passaram de um sonho?... Onde vocês estão? Onde?" (p.177-8)*. Este final é a marca da quebra de qualquer ilusão que possa ter havido durante a representação, pois fica claro que McPherson quer nos lembrar que estávamos no teatro ouvindo uma história que nos foi narrada. Scott Cummings comenta que o papel do contador de histórias é semelhante ao papel do vampiro, que atrai suas vítimas ou ouvintes e explora sua ingenuidade e credulidade (2000, p.308). Assim como o vampiro suga o

\footnotetext{
* So, were they real? Or were they a dream?... Where are you? Where?
} 
sangue de suas vítimas, sangue que simboliza a vida, a vitalidade e a essência do homem, o contador de histórias que só se interessa pela "arte pela arte", irá privar os ouvintes da capacidade de refletir, de racionalizar.

Histórias são tão importantes que é a história contada por William que faz o protagonista querer voltar para o convívio de sua família. Enquanto morou com William, o narrador passava parte de seu tempo no quarto lendo ou tentando escrever. O vampiro visitava-o com frequência e uma vez contou uma história sobre um madeireiro que resgatou um velho de um poço profundo, e como recompensa, ganhou um relógio. Mais tarde, descobriu que se voltassem os ponteiros do relógio, ele conseguia voltar no tempo. O madeireiro não fez uso do relógio até que sua esposa morreu. Então, toda vez em que se sentia só, ele voltava os ponteiros do relógio para o tempo em que a esposa vivia. Um dia, ao voltar muito e encontrar a esposa ainda criança, brincando de boneca, o relógio quebrou deixando-o preso no passado. Desesperado, ele agarrou a esposa-criança e fugiu para a floresta, sendo perseguido pelo povo da cidade que o espancou até matá-lo. Depois de ouvir tal história, o protagonista-crítico indaga pelo seu significado e quando nota que o vampiro é incapaz de refletir sobre o que foi dito, percebe que a grande diferença entre os vampiros e os seres humanos é a capacidade de ter consciência; o protagonista escolhe então viver sua vida de forma consciente. Esta história dentro de outra mostra que, na obra de Conor McPherson, encontramos uma dimensão meta-narrativa. Podemos falar em histórias sobre o contar histórias e na maioria delas percebemos traços do sobrenatural, como explica Scott Cummings:

McPherson flirts with the improbable and the unbelievable first and foremost for the sheer fun of it and then as a way of drawing attention to the psychology of storytelling. When regarded collectively, his body of work demonstrates self-consciousness about the mechanics of McPherson's craft that adds a meta-narrative dimension to his tall tales. They become, in part, stories about storytelling.

(CUMMINGS, 2000, p.306)

Pode-se afirmar que o palco vazio seria mais um recurso para não nos fazer esquecer de que estamos no teatro, pois objetos ou cenário poderiam criar uma ilusão ou fazer os espectadores desviarem a atenção do que está sendo dito nesse 
palco. Clare Wallace comenta que o fato de a peça ser em forma de monólogo permite que o espaço do palco mantenha-se indefinido em termos de tempo e lugar, enquanto que tudo o que é descrito ou narrado tenha que ser reconstruído na imaginação dos espectadores (2006, p.48). O mesmo efeito talvez não fosse obtido se Conor McPherson tivesse optado por contar a história deste crítico de teatro através de um conto. Possivelmente teríamos um conto gótico ou somente uma história de vampiros. Além disso, McPherson subverte a tradição: St Nicholas não é uma história de terror nos moldes dos contos de Le Fanu e do Drácula de Stoker; o dramaturgo faz uma paródia, utiliza-se de elementos dessas obras com humor e irreverência para demonstrar que o protagonista-crítico vivia como um vampiro. fato de o protagonista relatar que conviveu com vampiros e não com fantasmas, lobisomens ou outros seres do mundo sobrenatural, também é significativo, pois os vampiros encarnam aquilo que mais ultrapassa a capacidade de compreensão - 0 desejo e a morte. Mesmo no nosso século, quando o homem é capaz de entender e dominar a ciência e a tecnologia, o medo da morte, do desconhecido ainda é muito presente. A boca sedenta de um vampiro sugando o sangue é semelhante à dor provocada pela passagem destrutiva do tempo, que suga a energia vital do homem. Enfim, vampiros são criaturas que representariam os medos básicos do ser humano.

Em St Nicholas, McPherson usou o tema do vampiro e da criação de histórias por meio do monólogo, para resgatar a crença no ser humano; depois que o crítico de teatro passou uma temporada com os mortos-vivos, ele, que estava morto por dentro, encontra nova vida. No próximo capítulo a análise de The Weir mostrará como o dramaturgo utiliza - não monólogos - mas o contar histórias (storytelling) para trazer à tona emoções contidas e verdades dolorosas. 


\section{CAPÍTULO 2}

\section{The Weir: O Efeito de Histórias Sobrenaturais}

Since then, at an uncertain hour, that agony returns; And till my ghastly tale is told, this heart within me burns.

S. T. Coleridge

O marinheiro em The Rime of the Ancient Mariner - A Balada do Velho Marinheiro, de S. T. Coleridge é escravo do impulso e da necessidade de contar a história de seu crime e prolongado castigo aos mais diversos ouvintes, como se estivesse repetindo a confissão de seu pecado várias vezes. Seu castigo final é conviver com essa compulsão de contar sua história. Em The Weir, em um bar numa remota parte da Irlanda, quatro personagens masculinas narram histórias para impressionar uma jovem recém chegada de Dublin. São histórias sobrenaturais que precisam ser contadas para que as personagens possam compartilhar e enfrentar seus medos e verdades dolorosas.

Conor McPherson explica que The Weir é inspirada nas histórias que ouvia durante as visitas ao avô, que morava sozinho numa casinha no campo próximo ao Rio Shannon, em Leitrim. Durante estas visitas ficava ao lado da lareira ouvindo seu avô; e ao deitar, antes de dormir pensava nas histórias e a escuridão, o isolamento e o silêncio do campo irlandês aguçavam sua imaginação (WOOD, 2003, p.43). Não é 
difícil perceber que muitas destas narrativas devem ter servido como pano de fundo na criação de The Weir.

Diferentemente dos monólogos anteriores, nos quais as rubricas eram poucas ou mesmo inexistentes, em The Weir as indicações cênicas são mais longas e bem mais detalhadas. Esta peça foi escrita para o "Royal Court Theatre" em Londres para ser dirigida por lan Rickson. Como essa foi a primeira vez que McPherson não dirigiu seu próprio trabalho, talvez por essa razão ele tenha usado rubricas mais detalhadas, contendo não só a lista de personagens, mas também uma longa descrição do cenário, figurino de cada personagem e muitas indicações de movimentos e pausas durante a peça. McPherson declarou em entrevista publicada em sua segunda coletânea de peças, que embora ele estivesse envolvido em todo o processo, como por exemplo, nas audições para escolha dos atores, bem como durante a primeira e a última semana dos ensaios, achou muito estranho trabalhar com outro diretor (McPHERSON, 2004b, p.216). No entanto, para nós leitores, fica mais fácil imaginar The Weir no palco do que suas quatro peças anteriores que possuem poucas rubricas.

The Weir se passa no presente, num pequeno bar na Irlanda rural, mais precisamente no noroeste de Leitrim ou Sligo, que são distritos vizinhos, na mesma região em que morava seu avô. O bar de The Weir é bem isolado, pois é parte de uma casa em uma fazenda. Em seu interior há um balcão com três bancos, uma lareira, uma mesa com algumas cadeiras, uma poltrona mais confortável próxima da lareira e outra mesa menor com duas cadeiras. As garrafas de bebidas não estão organizadas, somente deixadas na prateleira. Através desta descrição, imagina-se um bar mais caseiro, com poucos clientes, bem diferente dos pubs lotados de Dublin. Na primeira produção de The Weir, Rae Smith, responsável pelo projeto do cenário, propôs que o público sentasse em cadeiras e bancos de diferentes tamanhos e tipos para dar a impressão que faziam parte do bar; McPherson comentou que tal arranjo foi muito bom, pois contribuiu para o envolvimento dos espectadores, como se todos estivessem no meio da ação. (McPHERSON, 2004b, p.216).

Como a peça foi escrita em 1996, anterior à lei proibindo fumar em ambientes públicos fechados, datada de março de 2004, as personagens fumam dentro do bar durante a peça. Talvez em montagens mais recentes as ações e diálogos relacionados ao cigarro tenham que ser alterados, como por exemplo, uma 
personagem saindo para fumar, isso caso se queira atualizar a peça para os dias de hoje.

$\mathrm{Na}$ parede do bar podemos ver três fotografias antigas em preto e branco: a primeira mostra uma abadia em ruínas, na segunda vê-se de cima uma pequena cidade localizada em uma baía com algumas montanhas ao fundo, uma típica imagem da zona rural irlandesa que é muito comum em calendários e guias turísticos; a terceira foto mostra pessoas ao lado de uma represa recém construída. Essa última fotografia é de extrema importância, pois elucida o título da peça: Weir, represa, açude. Uma das personagens comenta que tal represa foi construída em 1951 e explica sua função, "controlar a água para gerar energia para a área e também para Carrick" (McPHERSON, 2004b, p.32). * McPherson explica que num lado de uma represa a água está calma e tranquila, do outro lado está contida, esperando para escoar. (WOOD, 2003, p.48). Através das histórias sobrenaturais trocadas no bar, emoções antigas são liberadas e vêm à tona, deixando as personagens à vontade para compartilhar histórias mais íntimas que irão aprofundar o relacionamento entre elas e promover descobertas pessoais. Brad Kent, no artigo intitulado McDrama: The Sentimental in Martin McDonagh's The Beauty Queen of Leenane and Conor McPherson's The Weir, observa também que o título simboliza o represamento de emoções, pois assim como numa represa de águas aparentemente calmas e profundas, as personagens mantêm antigas emoções escondidas do mundo exterior (2003, p.37). Assim sendo, o título The Weir, nos remete à imagem de água represada e depois liberada que pode ser associada com emoções e medos contidos que serão enfrentados ao longo da peça.

A lista das cinco personagens contém somente os primeiros nomes com as respectivas idades: Jack, cinquenta anos - Brendan, trinta anos - Jim, quarenta anos - Finbar, entre quarenta e oito e quarenta e nove anos - Valerie, trinta anos. Valerie e Brendan são os mais jovens, Jack e Finbar têm praticamente a mesma idade e Jim não é tão jovem. São todos adultos que aos olhos da sociedade já deveriam estar estabelecidos na vida. Os sobrenomes das personagens masculinas nos são fornecidos durante a peça principalmente quando Finbar está apresentando Valerie para os demais, Jack Mullen, Brendan Byrne, Jim Curran e Finbar Mack. Os nomes Finbar e Brendan são de origem irlandesa, enquanto que os nomes Jim e Jack vêm

\footnotetext{
" "to regulate the water for generating power for the area and for Carrick as well."
} 
do hebraico, mas são nomes bem comuns em países de língua inglesa, muitas vezes são abreviações para James e John, respectivamente. Os sobrenomes Mullen, Byrne e Curran também são irlandeses, já o sobrenome de Finbar - Mack - é de origem escocesa, mas comum na Irlanda. Nunca descobrimos o sobrenome de Valerie, talvez para manter a atmosfera de mistério que envolve a personagem. $\mathrm{E} O$ nome Valerie é de origem latina e significa "ser forte". Analisando a origem dos nomes e sobrenomes percebe-se que eles também caracterizam as personagens.

As rubricas ainda fornecem detalhes sobre o que as personagens estão vestindo. Jack, o primeiro a entrar em cena, usa um terno grande demais com o colarinho da camisa branca aberto e um casaco impermeável bem sujo que ele retira e pendura nos ganchos ao lado da porta, enquanto enxuga agressivamente as botas no capacho. Tais ações nos fazem imaginar que provavelmente esteja frio ou chovendo e que Jack não está nos seus melhores dias. Quando vai até o balcão se servir de um copo de Guinness e constata que a torneira está com problema, Jack decide pegar uma garrafa e ele mesmo consulta a lista de preços, vai até a caixa registradora, paga pela cerveja e retira seu troco. Sua atitude confirma o fato do bar ser um ambiente bem caseiro, onde Jack além de se servir, tem liberdade para abrir a caixa registradora.

Brendan, o dono do bar, entra em seguida com um balde de turf, combustível vegetal retirado dos bogs (pântanos) da Irlanda. É interessante observar que o turf que ele usa foi retirado mecanicamente e não manualmente, pois vem em blocos, briquettes, fato que nos mostra um pouco da modernização do lugar. Enquanto Brendan se ocupa dos afazeres do bar, os dois conversam sobre os mais diversos assuntos. Falam sobre a torneira quebrada: “O que está errado com a Guinness?"... "É a pressão da torneira.", sobre o tempo, "Que vento, hein?" (McPHERSON, 2004b, p.14) ${ }^{*}$ Mencionam as irmãs de Brendan que o visitaram naquela tarde para persuadi-lo a vender uma parte do terreno da fazenda e comentam também o fato de Jack ter ido a Carrick apostar em cavalos. Lá Jack encontrou Jim que contou sobre Finbar ter vendido ou alugado uma casa da região, a casa de Maura Nealon, desocupada há mais de cinco anos para uma moça de Dublin, Valerie. Ao comentarem o fato que Finbar, o único casado entre eles, passeia pela região com Valerie, eles concluem ironicamente, que não há nada melhor do que a

\footnotetext{
* "What's with the Guinness?"..." It's the power in the tap." "That's some wind, isn't it?"
} 
independência da vida de solteiro. Assim, observamos que eles têm um pouco de inveja de Finbar, que não é sozinho. Neste momento entra Jim que também retira seu casaco impermeável revelando o pulôver de lã bem colorido que está usando. Os três continuam bebendo, fumando e conversando sobre o tempo, falam também da mãe de Jim, que está doente e lembram que os turistas - "os alemães"- estão prestes a chegar. Ouvem então o barulho do carro de Finbar que entra com Valerie. Ele veste um terno bege e ela jeans e suéter. Depois das apresentações, a conversa segue com Finbar mostrando as fotografias, explicando que a foto da vista tão bonita foi tirada do topo do terreno de Brendan e fala sobre histórias relacionadas com fadas que fazem parte do folclore da região. As ações deste início da peça dão-lhe um cunho realista que contrasta com o que virá a seguir, pois a partir daí ela toma outro rumo.

Aparentemente esses diálogos com frases curtas não passam de conversa corriqueira entre conhecidos numa mesa de bar. No entanto, constroem pouco a pouco, cada personagem. Jack o mais velho deles, tem uma oficina de carros, aposta em cavalos, mora sozinho e quase nunca sai da região. Jim ainda mora com a mãe, que está velha e doente, não tem um emprego fixo, é um "faz tudo" que às vezes ajuda Jack na oficina. Finbar mudou-se para Carrick, é o que está em melhores condições financeiras, pois além de trabalhar como corretor de imóveis, tem um hotel na cidade e é o único que está casado. Brendan, o mais jovem, também mora sozinho, mas recebe visitas frequentes das duas irmãs que estão mais interessadas em verificar como vão os negócios no bar e na fazenda do que nele. Elas querem vender o terreno de onde a foto da vista foi tirada para comprar carros novos para os maridos.

As conversas constroem as personagens e os diálogos esparsos não deixam a peça monótona, pois eles se entrelaçam com as histórias, tornando-as mais interessantes e pessoais.

BRENDAN. That's the view of Carrick from our top field up there.

VALERIE. It's an amazing view.

FINBAR. Oh I'd say that's probably one of the best views all around here, wouldn't it be?

JIM. Oh yeah, it would be. 
FINBAR. You get all the Germans trekking up here in the summer, Valerie. Up from the campsite.

VALERIE. Right.

FINBAR. They do come up. This'd be the scenic part of all around here, you know? There was stories all, the fairies be up there in that field. Isn't there a fort up there?

BRENDAN. There's a kind of a one.

VALERIE. A fairy fort?

FINBAR. The Germans do love all this.

BRENDAN. Well there's a...ring of trees, you know.

FINBAR. What's the story about the fairy road that... Who used to tell it? BRENDAN. Ah, Jack'd tell you all them stories.

Neste trecho nota-se que os comentários em torno da fotografia da vista da cidade não só inspiram a primeira história da peça, como também elucida que os turistas no verão vêm em busca de paisagens campestres e histórias de uma Irlanda mítica. Assim, o contar histórias segue de forma natural dentro do diálogo. Mas qual a importância de se contar histórias?

Richard Kearney afirma que contar histórias é tão intrínseco ao ser humano como o ato de comer e que assim como a comida nos mantém vivos, as histórias fazem nossas vidas valerem a pena (2002, p.3). Kearney acrescenta que quando alguém nos pergunta quem somos, respondemos com nossa história, ou melhor, a narrativa de nossa vida presente, repleta de memórias passadas e com algumas perspectivas para o futuro. Tais narrativas nunca são inocentes, pois cada história é contada de certa perspectiva em detrimento de outras. Assim, a narrativa de Jack, a primeira da peça, fornece a sua visão sobre o que Maura Nealon testemunhou. Depois que Valerie narra sua história, Finbar comenta que Maura seria uma alcoólatra que pode ter inventado tudo, mas Jack a defende, "Vocês estão sendo injustos com ela. A mulher está morta, ela não pode se defender." (McPHERSON, 2004b, p.62) * Mais do que uma tentativa de preservar a imagem de Maura, ele está defendendo a veracidade de sua versão.

Kearney não acredita que o ato de contar histórias desaparecerá com o advento da cultura cibernética, ou era da informática, onde informações "viajam"

\footnotetext{
" "Ah you're not being fair on her now. The woman's dead, she can't defend herself".
} 
rapidamente em forma digital, abandonando formas de expressão escritas manualmente como, por exemplo, cartas. Para Kearney, o ato de contar histórias nunca deixará de existir. Certamente novas tecnologias podem alterar as formas de interação ou até priorizar narrativas não lineares, mas sempre existirá alguém disposto a contar e outro alguém querendo ouvir uma boa narrativa (2002, p.126). Histórias são de suma importância, pois são capazes de alterar nossas vidas quando retornamos do texto para a ação. Quando ouvimos uma narrativa somos levados para um outro tempo e lugar, podemos vivenciar uma outra vida, nos colocar na pele de outra pessoa, ver o mundo de um ponto de vista diferente do nosso próprio, que modificará nossa maneira de pensar e ser. Se para muitos o teatro é apenas uma forma de entretenimento, acredita-se que o teatro é, sobretudo, um instrumento social com inúmeras funções. Além de difundir e preservar o patrimônio artístico de várias culturas, o teatro é capaz de gerar reflexões, polemizar, politizar, revolucionar, transformar e tornar as pessoas mais conscientes e ativas. Em The Weir, depois de uma noite contando e ouvindo histórias, as personagens certamente irão acordar diferentes no dia seguinte.

Contar histórias sempre foi parte central na cultura irlandesa. No livro Storytelling in Irish Tradition, Séan Ó Súilleabháin explica que na época em que livros, jornais e revistas eram muito raros ou difíceis de adquirir e quando nem o rádio ou a televisão haviam sido inventados, o povo irlandês tinha que prover seu próprio entretenimento. Música, dança e esportes faziam parte da diversão mas, principalmente nos lugares em que a língua irlandesa ainda era falada, o contar histórias era a forma mais popular de passar o tempo (1973, p.10). Segundo Séan ó Súilleabháin (1973), o bom contador de histórias tinha um repertório vasto guardado na memória; geralmente em sua própria casa ou sentado no lugar de honra na casa de um vizinho ou até mesmo num velório, bem próximo da lareira, contava suas histórias para uma platéia atenta nas noites longas de inverno; embora elas fossem mais apropriadas para adultos, crianças se escondiam para ouvi-las e algumas até ajudavam a fazer as tarefas diárias dos contadores de histórias porque assim eles estariam mais descansados e livres para contar longas lendas folclóricas durante a noite. Embora existissem mulheres contadoras de histórias, a maioria sempre foi de homens e considerava-se má sorte contar histórias durante o dia, ainda que existam relatos de contadores que aprenderam muitas narrativas enquanto recolhiam o feno 
ou trabalhavam nas plantações colhendo batatas. Assim, mitos e lendas eram passados oralmente de geração para geração.

Súilleabháin explica que durante o período da grande fome (1845-49), muitas pessoas andavam pelas estradas em busca de comida e abrigo, e se num grupo alguém tivesse a reputação de ser um bom contador de histórias, essa pessoa era bem recebida para passar até mais de uma noite em casas da região que ficavam lotadas para ouvir não só histórias como também notícias trazidas de outras áreas. Algumas vezes, esses contadores de histórias eram seguidos até a fazenda vizinha por pessoas que gostavam de ouvir as mesmas narrativas novamente (1973, p.12). Mas de onde se originaram elas?

Em seu livro Mitos e Lendas Celtas: Irlanda, Angélica Varandas (2006) esclarece que todo um conjunto de narrativas que têm suas raízes num passado pré-cristão, foi divulgado por via oral e que muitas histórias foram registradas em manuscritos pelos monges copistas que cristianizaram a Irlanda. Por esta razão, alguns heróis míticos conviviam com santos cristãos nas narrativas. Varandas também comenta que tais histórias eram normalmente escritas em prosa, pois a poesia estava reservada para a tradição cristã sagrada; a prosa, em geral anônima, era um gênero mais vulgar e não tinha o prestígio da poesia, considerada sublime. No entanto, a autora explica que a mistura de prosa e verso era uma combinação bem frequente nas histórias Irlandesas e acrescenta que um manuscrito do século XII ou XIII pode ter sido uma cópia de um texto escrito originalmente nos séculos VII ou VIII.

Com o objetivo de estudar esses manuscritos de uma maneira mais organizada, eles foram classificados em três ciclos: o ciclo mitológico, o ciclo heróico e o ciclo de Fionn. O ciclo mitológico reserva-se às histórias sobre deuses e deusas, muitas vezes combinando descrições dos campos irlandeses com seus rios, árvores e morros com elementos do sobrenatural; como por exemplo, feiticeiros capazes de atirar as montanhas da Irlanda contra os inimigos e esconder os rios da Irlanda para que os oponentes ficassem sem água, além de druidas e curandeiros dotados de poderes mágicos. A ação das narrativas deste ciclo se desenrola na região central da Irlanda, que hoje compreende Newgrange e Tara. Acreditava-se que a região era povoada pelos Tuatha Dé Danann, os Habitantes do Outro Mundo que combatiam os Fomhoiri, demônios que habitavam anteriormente o local; com a invasão dos Celtas os Tuatha Dé Danann teriam sido obrigados a viver embaixo da terra e do 
mar, deixando a superfície para os mortais. Além das narrativas de batalhas entre os deuses e demônios, há histórias sobre expedições ou navegações para ilhas imaginárias, onde não existe tempo cronológico e as mulheres são eternamente jovens e belas. Estas viagens foram os textos mais cristianizados do ciclo segundo Varandas (2006, p.24).

O ciclo heróico se divide em ciclo de Ulster, no qual se narram as aventuras dos heróis de Ulster - região norte da Irlanda - e o ciclo histórico ou ciclo dos reis, no qual encontramos narrativas sobre feitos heróicos de reis e nobres. O ciclo de Ulster, também conhecido como ciclo do Ramo Vermelho, tem como personagens principais Conchobhar, rei de Ulster no início da era cristã, Cúchulain e seu filho Conlaoch. São histórias que exaltam na guerra os atos heróicos como lealdade, coragem e honestidade. Os grandes rivais do rei de Ulster são a rainha Medb e o rei Aillil de Connachta. Uma das narrativas mais conhecidas pertencentes a este ciclo chama-se $O$ Exílio dos Filhos de Uisliu, que narra o amor trágico entre Deirdre e Naoise, que "prefigura a história de Tristão e Isolda, celebrizada na Idade Média" (VARANDAS, 2006, p.24). Para entendermos os contos do ciclo dos reis, devemos compreender o fato de que toda a organização social celta se baseava na realeza sagrada; o rei representava a divindade, o deus tribal que se casava ritualmente com a deusa-mãe, que, por sua vez, simbolizava a Terra; portanto muitas narrativas do ciclo dos reis apresentavam como tema principal esse casamento ritual e sagrado. Um texto bastante relevante deste ciclo é o Livro das Invasões da Irlanda que conta como seis raças míticas diferentes ocuparam a ilha depois do Dilúvio (VARANDAS, 2006, p.25).

O terceiro ciclo, de Fionn, narra as aventuras de Fionn MacCool, de seu filho Ossian e de seus guerreiros, os Fianna. Muitas narrativas deste ciclo são marcadas pela rejeição das convenções da tribo e a fuga para o mundo verde, buscando o contato com a natureza, onde ocorreriam acontecimentos naturais e sobrenaturais. Acallam na Senórach (A Conversa dos Anciãos) é considerado o maior texto literário da Irlanda antiga, com centenas de histórias e poemas em forma de baladas sobre Fionn e os Fianna. Tais baladas mostram a importância assumida pela música, associada à arte de contar histórias, ao longo do período medieval, quando instrumentistas e cantores eram tratados com especial respeito. Segundo Varandas entre todos os artistas europeus medievais, os irlandeses eram os que mais se sobressaiam, devido à excelente qualidade de sua música. "Acreditava-se que 
muitos deles eram seres sobrenaturais, vindos do mundo mágico dos Sídhe, as fadas da Irlanda, no qual a música e a poesia se fazem ouvir em todos os momentos do dia" (VARANDAS, 2006, p.251). O conjunto de histórias sobrenaturais irlandesas aqui discutidas demonstra a persistência do interesse do povo em geral pelas forças ocultas que irá aparecer nas narrativas de The Weir.

No primeiro relato em The Weir surge o mundo mágico das fadas. Jack informa que a história se passou na casa de Maura Nealon, onde Valerie irá morar, e que a própria Maura Ihe contou. Primeiro ele explica que Bridie, mãe de Maura, quando era jovem, estava sempre pregando peças nas outras crianças, fazendo brincadeiras como esconder roupas ou avisar que havia alguém batendo na porta. Numa noite de sábado em 1910 ou 1911, Bridie já era viúva e enquanto seus filhos e filhas mais velhos estavam se arrumando para irem ao baile, ela ouviu uma batida na porta da frente da casa, desceu as escadas e pediu para os filhos abrirem a porta, mas eles não viram ninguém. Os filhos saíram sem dar muita importância ao acontecido, deixando Bridie e Maura, que ainda era criança, sozinhas na casa. Normalmente, Bridie teria mandado Maura dormir, mas naquela noite as duas permaneceram no andar térreo da casa. Neste ponto da história, Jack faz um comentário: "Naquele tempo, Valerie, você sabe, não havia eletricidade aqui. E não há escuridão igual a uma noite de inverno no campo. E havia um vento, como o vento desta noite, uivando e assoviando, vindo do mar. Você ouve o vento entrando por debaixo da porta, como se alguém estivesse cantando, cantando debaixo da porta para você" (McPHERSON, 2004b, p.36). ${ }^{*}$ Tal comentário reforça a imagem que fizemos do tempo no início da peça quando Jack entra em cena e também cria uma atmosfera própria para histórias de terror; ao interromper o relato, Jack provoca o suspense no leitor, que fica querendo saber o que vem depois.

Jack continua contando que Maura e Bridie estavam sentadas próximas à lareira quando ouviram batidas na porta numa altura que normalmente um adulto não bateria, pois as batidas eram mais próximas do chão e não no alto da porta. Bridie não deixou Maura abrir a porta alegando que deveria ser uma brincadeira. Embora ainda uma criança, Maura foi capaz de perceber a inquietação da mãe quando as batidas passaram para as janelas da casa. As duas permaneceram lá até

\footnotetext{
* "And those days, Valerie, as you know, there was no electricity out here. And there's no dark like a winter night in the country. And there was a wind like this one tonight, howling and whistling in off the sea. You hear it under the door and it's like someone singing. Singing in under the door at you."
} 
os irmãos chegarem bem depois da meia-noite e não levantaram nem para pegar turf para manter o fogo aceso. Segundo Jack, Maura ainda contou que uns dias depois um padre veio benzer as portas e janelas e os barulhos não foram mais ouvidos até o ano em que a represa, the weir, foi construída quando também apareceram muitos pássaros mortos na área. Quando Valerie pergunta a causa dos barulhos, Jack explica que Maura ouviu dos mais velhos da região que a casa havia sido construída no caminho que as fadas percorriam para se banharem, conhecido como fairy road. Havia o forte das fadas no topo do terreno de Brendan, um poço antigo, a abadia e uma pequena praia. A lenda diz que as fadas desciam do forte até a praia e com o bloqueio da construção, as fadas teriam que passar por dentro da casa.

Fadas fazem parte da tradição popular irlandesa e relatos sobre elas foram transmitidos oralmente durante séculos. Referências escritas sobre o mundo delas são muito raras até o século XIX, quando escritores como W.B. Yeats e Lady Augusta Gregory começaram a recolher narrativas orais e registrá-las em inglês. Deste material surgiram as obras de Yeats Fairy and Folk Tales of the Irish Peasantry (1888) e Irish Fairy Tales (1892), compilados em 1973 sob o título Fairy and Folk Tales of Ireland. Em 1920 é publicada a obra de Lady Gregory, Visions and Beliefs in the West of Ireland. Angélica Varandas afirma que tais obras são ainda hoje as melhores fontes sobre a vida das fadas e outras aparições de espíritos irlandeses. Munira Mutran (2002), em Álbum de Retratos, explica que William Butler Yeats via a Irlanda como cera macia e acreditava que seu papel como poeta e dramaturgo, seria reviver e dar forma a uma tradição literária irlandesa. Assim, Yeats não pretendia só reproduzir literalmente as histórias do folclore irlandês, mas recriálas com o intuito de assegurar ao seu povo a riqueza, beleza e importância de sua própria cultura. Esperava que tanto leitores quanto escritores conhecessem os períodos cheios de imaginação da História da Irlanda. (MUTRAN, 2002, p.174). O mundo sobrenatural está presente em muitas peças de Yeats; em The Countess Cathleen (1892) há a presença de seres angelicais e de dois demônios que se tornam mercadores de almas e em The Land of the Heart's Desire (1894), uma representante das fadas aparece na forma de uma criança para convencer uma jovem recém-casada a acompanhá-la ao seu mundo, um lugar onde ninguém envelhece e não há a enfadonha rotina dos afazeres domésticos. Fernanda Mendonça Sepa, em O Teatro de William Butler Yeats: Teoria e Prática, conclui que 
Yeats tinha em mente a recriação da mitologia celta numa Irlanda moderna, pelo uso de histórias e lendas dos camponeses irlandeses, histórias em que o sobrenatural estivesse presente, pois Yeats acreditava que assim despertaria a imaginação irlandesa. (1999, p. 30).

Ele foi o primeiro autor que dividiu o mundo das fadas irlandesas em aquelas que andam em grupos, Trooping Fairies, e as que agem sozinhas, as fadas solitárias - solitary fairies. As trooping fairies, segundo Yeats, procuram evitar os humanos, mas se seus caminhos se cruzam, as consequências são imprevisíveis, pois elas tanto podem fazer o bem quanto o mal. Por viverem só o presente intensamente, elas não têm critérios racionais. No entanto, os irlandeses se referem a elas como o "Povo Bom", para elogiá-las e assim evitar que se ofendam, pois quando ficam ofendidas há sempre interferências negativas para os humanos, como destruição de colheitas, doenças ou até morte.

Dizem que as fadas que vivem em grupos moram em palácios de ouro e cristal escondidos debaixo da terra ou do mar; tais moradias são por vezes chamadas de fortaleza encantada (VARANDAS, 2006, p.263) que nos remetem ao forte das fadas no topo do terreno de Brendan em The Weir. Talvez a razão de Brendan não vender e nem usar esta parte da propriedade seja o receio de incomodar as fadas. W.B.Yeats (2003, p.4) menciona que as trooping fairies vêm à superfície da terra em cavalos muito rápidos, sendo impossível vê-los, pois se levanta uma grande nuvem de pó, como se um vento forte levasse tudo por onde passa. Esta ventania lembra o vento uivando, assoviando e cantando por debaixo da porta da casa de Maura.

Além disso, as fadas gostam de vestir-se com roupas de cores vivas e apreciam música e dança. Geralmente dançam durante a noite em grandes círculos que, segundo Angélica Varandas, podem ser chamados de círculos mágicos ou encantados. Elas costumam dançar mexendo as pernas rapidamente até gastarem as solas dos sapatos ou até mesmo a ponta dos dedos dos pés. Entre as coisas ruins que elas podem fazer aos humanos, a pior seria raptar os bebês fortes e saudáveis deixando no lugar um changeling, ou melhor, um bebê feio, aleijado, com um apetite insaciável, que fica gritando a noite inteira. Para evitar que tal coisa aconteça, a mãe deve manter seu bebê sempre limpo e acima de tudo, batizá-lo. Para manter as fadas afastadas de casa, é necessário benzer com água benta as portas e janelas da casa ou acender um fogo, pois elas costumam ter medo das 
chamas. Varandas ainda acrescenta que não se deve retirar pedras das florestas habitadas por fadas, muito menos "construir barragens nos seus rios" (2006, p.265). Através desta descrição percebemos que as fadas de The Weir possuem muitas semelhanças com as trooping fairies.

Já as fadas solitárias, como o próprio nome diz, andam sozinhas e se sentem muito atraídas pelo mundo dos mortais. Por isso, visitam os humanos com frequência, levando presentes que podem ser perigosos ou até mesmo fatais. Acredita-se que são seres aliados do Diabo e por isso agem com instintos maléficos. Dentre as fadas mencionadas por Yeats (2003) vale a pena citar as seguintes: Leanhaun Shee (fairy mistress) que procura o amor de um mortal. Quanto mais cruel ela é, mais os homens a desejam e entre seus amantes favoritos estão os músicos e poetas; Far Darrig, Homem Vermelho, sempre se veste de vermelho e embora aterrorize os humanos, traz sorte se encontrado; Fear-Gorta (Man of Hunger) é muito magro e está sempre coberto de farrapos, circula pelas estradas e abençoa quem lhe dá esmolas voluntariamente; e o mais interessante deles é o Leprechaun, criatura de pequena estatura, corpo feio, rosto enfezado e todo enrugado que sempre veste roupas de cor cinza ou marrom, gosta de fumar cachimbo e beber cerveja. Entretanto, os Leprechauns são muito trabalhadores, pois estão sempre consertando os sapatos das fadas gastos pela dança incessante e são os guardiões do tesouro delas. Se por um lado há o Povo Bom que não se preocupa com o futuro, pois só vivem para o presente, por outro há os Leprechauns, que mantêm ouro e pedras preciosas em panelas e caldeirões fechados e enterrados longe da cobiça dos homens. Dizem que só um arco-íris pode revelar o esconderijo. O Leprechaun de hoje em dia foi transformado em um pequeno e simpático anão de casaca verde, chapéu alto e verde e calças vermelhas, vendido em lojas para turistas como o mais alto representante das fadas do país.

Na primeira história contada em The Weir, a presença do sobrenatural está nas fadas, só que elas estão fora da casa, não são vistas por ninguém e mesmo a explicação de que elas podem ter sido as responsáveis pelas batidas na porta e janelas veio bem depois do acontecido. Além disso, Jack conta apenas o que ouviu de Maura, nada se passa diretamente com ele. Margaret Llewellyn-Jones sugere, no entanto, uma possível ligação entre Jack e a história; o caminho bloqueado das fadas representaria as oportunidades perdidas por Jack no passado (2002, p.98). Comentaremos tal sugestão quando analisarmos a última narrativa da peça, também 
contada por Jack. Por enquanto, nota-se que o sobrenatural ainda está distante das personagens; à medida que se relatam outras histórias, os elementos sobrenaturais se aproximam das personagens/narradores e tornam-se mais críveis.

O diálogo prossegue, Jack paga mais uma rodada, e oferece cigarros a todos. Finbar mostra-se surpreso quando Valerie aceita um cigarro de Jack, talvez porque mulheres fumando e bebendo vinho sejam hábitos mais urbanos, e comenta que parou de fumar há dezoito anos, pouco antes de mudar-se para Carrick. Este fato vai dar origem à segunda história da peça, pois Jack insiste que Finbar conte a Valerie o que aconteceu.

Finbar diz que no ano em que seu pai morreu, a família Walsh foi morar numa casa bem próxima da sua. O pai era sargento em Carrick e a mãe ficava só com as três filhas adolescentes enquanto ele trabalhava. Numa noite, por volta das onze horas, a senhora Walsh bate em sua porta solicitando ajuda para a filha menor, Niamh. A mãe relata que Niamh ligou assustada pedindo para que ela a pegasse na casa da amiga onde ao brincar com uma ouija board*, atraíram um espírito. É claro que a mãe foi buscá-la imediatamente e na volta ficou muito impressionada porque um cachorro enorme seguiu o carro correndo e latindo muito alto. Já em casa, Niamh não parava de chorar alegando que havia uma mulher parada na escada olhando para ela. Finbar fora até lá para tentar acalmar a menina e a encontrou enrolada num cobertor, pálida, branca de pavor. Sugeriu que a mãe telefonasse para o médico, Joe Dillon, e o padre Donal para benzer a casa. Depois que o médico deu um sedativo para Niamh, eles conversavam com a senhora Walsh quando o telefone tocou. Era o filho mais velho, que morava na antiga casa deles em Longford. Ele ligou para avisar que sua vizinha, uma senhora que costumava cuidar de Niamh, havia morrido ao cair da escada.

Comentando que só poderia ter sido uma estranha coincidência, Finbar conta que, quando voltou para sua casa naquela noite, estava fumando, sentado à lareira e sentiu que havia algo na escada que ficava bem atrás do lugar em que ele estava. Sem coragem de virar-se, ficou imóvel até o amanhecer, não alimentou o fogo com mais turf e nem conseguiu acender outro cigarro. Foi assim que parou de fumar.

\footnotetext{
* Ouija Board - Tabuleiro ou Tábua Ouija - é uma superfície plana com as letras do alfabeto e números, utilizada supostamente para comunicação com espíritos. No Brasil, há uma variante conhecida como a brincadeira do copo. Disponível em: <http://pt.wikipedia.org/wiki/Tabuleiro Ouija>. Acesso em: 19/12/2008.
} 
A segunda história tem algumas semelhanças com a anterior: a senhora Walsh bate à porta de Finbar tarde da noite, Maura e sua mãe ouvem batidas nas portas e janelas durante a noite, os três ficam em frente à lareira no andar de baixo de suas casas, sem alimentar o fogo e padres benzem as duas casas. Só que o relato contado por Finbar já é bem mais pessoal, pois além de ter sido chamado para ajudar Niamh, presencia o telefonema do filho mais velho, e quando volta para casa, ele também sente algo estranho que não deixa de afetar sua vida para sempre. Depois do incidente, além de parar de fumar, Finbar decide ir morar em Carrick, busca a agitação da cidade para evitar a solidão da zona rural. Como Jack comenta: "muda-se em busca das luzes da cidade" (McPHERSON, 2004b, p.44). Para Llewellyn-Jones, em Contemporary Irish Drama and Cultural Identity, Finbar nunca foi aceito totalmente pela comunidade - da mesma forma como os Walsh são chamados de "loucos" * - ele é visto como alguém "de fora". Llewellyn-Jones explica que a mulher na escada pode representar o olhar crítico da comunidade sobre ele (2002, p.99), uma explicação bastante pertinente, uma vez que desde o início da peça, Brendan, Jack e Tim criticam o comportamento de Finbar com relação à Valerie.

Na história contada por Finbar, o elemento sobrenatural é uma presença, um espírito, talvez o fantasma da senhora que morreu ao cair da escada. Todavia, a única pessoa que vê o fantasma é Niamh, a filha mais jovem, impressionada com a brincadeira das amigas de chamar os mortos. Até o padre sugere que tudo pode ser só imaginação dela. Há também um tipo de explicação para o cachorro que perseguiu o carro, pois Finbar menciona que é comum os fazendeiros terem cachorros grandes e que, naquela época, Willie McDermott tinha um cachorro enorme que à distância poderia até ser confundido com um pequeno cavalo. Em vez das fadas da primeira narrativa, McPherson emprega fantasmas na segunda.

No capítulo sobre fantasmas, Yeats explica que aqueles que morrem repentinamente são os candidatos mais prováveis para virem assombrar os vivos, porque estão ligados afetivamente a alguém, ou precisam resolver alguma pendência. Fantasmas vivem no estado intermediário entre este e o outro mundo, o dos mortos (YEATS, 2003, p.140). Angélica Varandas lembra que os fantasmas sentem uma inexplicável saudade da vida terrena, por isso continuam a viver nas

*Headbanger: (gíria) louco. 
casas que habitaram em vida e é comum relatos de fantasmas que surgem aos humanos durante a noite para anunciar uma morte iminente (2006, p.277). Na segunda história de The Weir, a mulher na escada pode representar o fantasma da própria senhora que morreu repentinamente e tinha uma ligação afetiva com a menina ou outro espírito anunciando a morte da senhora. Neste último caso, podemos ligar esta aparição com outra fada solitária da tradição popular irlandesa, a Banshee, capaz de prever a morte de um membro da família ou alguma pessoa bem próxima. Dizem que a Banshee pode surgir na forma de uma mulher jovem e muito bonita ou como uma matrona vigorosa e robusta. Às vezes aparece como uma velha repugnante e decrépita ou como uma mulher de cabelos longos e grisalhos, muito magra, de rosto pálido e olhos vermelhos de tanto chorar. Bob Curran, em seu livro Banshees, Beasts and Brides from the Sea: Irish Tales of the Supernatural, explica que a aparição da Banshee vem por vezes acompanhada de um gemido terrível de desespero e outras vezes de um grito extremamente triste semelhante a uma canção melancólica (1996, p.130). Não só as aparências das Banshees diferem, mas também a função delas. Alguns acreditam que elas aparecem para dar as boas vindas ao recém falecido na terra dos espíritos, outros acham que são criaturas de mau agouro, ou mesmo o fantasma de alguém que, injustiçado pela família que assombra, volta para anunciar a morte de um membro desta família. Para Varandas (2006, p.271) cada Banshee possui a sua família, "partilhando com as suas vitórias e sucessos e chorando com tristeza a sua morte". Quando a morte está próxima, a Banshee torce as mãos, arranca os cabelos e solta gemidos de dor. Além do mais, cabe à Banshee acompanhar a família em suas mudanças, como a família Walsh na história de Finbar, que tinha se mudado de Longford há pouco tempo.

Nota-se também que mesmo aqueles que narram as histórias, fazem algum tipo de comentário antes ou depois de contar que põem em dúvida a veracidade dos relatos. Antes de sua narrativa, Jack menciona que são apenas histórias antigas e Finbar, ao terminar seu relato, fala para Valerie não ficar impressionada, pois é o que se ouve por toda a região e tudo não passa de brincadeira. Os comentários de Jack e Finbar são dirigidos a Valerie, pois as narrativas já são conhecidas das outras personagens e talvez tais ponderações mostrem também uma preocupação com o bem-estar da moça que está só, o que pode indicar uma possível aceitação dela como parte da comunidade. 
O diálogo que liga a história contada por Finbar com a seguinte explora o fato de a região ser bem sossegada, e quando Valerie comenta que não tem nenhum plano ainda, só veio em busca de paz e sossego, todos caem na gargalhada e Jack responde que ela está no lugar certo porque ali paz e sossego é o que não falta. Jim então aconselha Valerie a manter o rádio ligado e oferece mais uma rodada de bebida, entretanto ninguém aceita, ele só paga o que vai consumir. Fato que demonstra a preocupação dos outros com Jim, que não tem muitos recursos e ainda precisa cuidar da mãe doente. Enquanto Brendan serve-lhe uma dose de whiskey, Jim coloca mais turf na lareira e Finbar olha o relógio. Valerie pergunta se ele precisa ir e ele diz que ainda não, mas menciona que no dia seguinte haverá um casamento em seu hotel. Quem irá casar é Nualla Donnelly, filha do falecido Declan Donnelly, amigo de Jim. Ao ouvir o nome do amigo, Jim lembra um acontecimento que ocorreu há mais de vinte anos. Nesta parte da peça, as ações das personagens podem a princípio parecer de pouca importância, mas as atitudes de Jim, contando o dinheiro antes de oferecer para pagar bebida aos outros e alimentar o fogo, demonstram que ele se preocupa com o bem-estar de todos antes de contar sua terrível história.

O padre de Glen, região próxima de Carrick, pediu a Jim e Declan Donnelly para abrir uma cova. Embora estranhassem que ele não tivesse conseguido ninguém da região para ajudá-lo, eles aceitaram o serviço. No dia seguinte estava chovendo muito e Jim, gripado e com febre alta, ignorou o conselho da mãe para ficar em casa e foi no carro do pai de Declan rumo a Glen, pois precisava do dinheiro que o padre havia prometido. Quando os dois chegaram ao lugar, o padre deu-Ihes galochas e duas pás e levou-os até um túmulo onde dois corpos, da mãe e do pai, já estavam enterrados; a cova seria para o filho, um homem de meia idade. Começaram a cavar e a chuva não parava; Jim sentia dores por todo o corpo; fizeram um intervalo para descansar e comer alguma coisa, mas Jim não comeu nada, só bebeu uns bons goles de poteen ${ }^{*}$. O carro fúnebre chegou, e os dois ficaram intrigados quando notaram que só duas ou três pessoas tinham vindo para o velório. Depois de aberta a cova, Declan voltou para capela em busca de uma lona para cobri-la enquanto Jim bebia os últimos goles da bebida. Neste momento, um homem de meia idade, usando terno, foi até Jim e nervosamente disse que eles

\footnotetext{
* Poitín ou poteen, tradicional bebida irlandesa destilada de alto teor alcoólico (90\%-95\%) considerada ilegal na República da Irlanda até março de 1997.
} 
haviam cavado no lugar errado; o lugar certo para abrir a cova seria ao lado do túmulo de uma garotinha. Jim, muito cansado e doente, fingiu que havia concordado com o homem que logo voltou para a capela. Ao comentar o ocorrido, Declan Ihe diz não ter visto ninguém no caminho entre a capela e o cemitério. Na manhã seguinte, Jim acordou tão mal que não pode ajudar Declan no enterro. Ao ler o jornal, viu no obituário a foto do homem para quem eles haviam aberto a cova: era parecidíssimo com o homem de terno do cemitério, o que levou Jim a pensar que ele havia encontrado um irmão, ou um parente próximo do falecido. Jim esqueceu o assunto até que numa noite Declan contou-Ihe que havia descoberto a verdadeira razão para o padre precisar de duas pessoas que não fossem de Glen para fazer o serviço, pois o homem que havia morrido tinha a reputação de ser um pervertido.

Se compararmos a história de Jim com as anteriores, percebemos que o elemento sobrenatural se aproximou mais do narrador, pois foi o próprio Jim quem viu e falou com o fantasma. Mesmo que tudo não passe de uma alucinação de Jim por causa da febre alta e da bebida muito forte, não devemos esquecer que ele nunca havia visto o homem antes, e só ficou sabendo de sua fama de pedófilo muito depois do enterro. Nas histórias anteriores, as fadas e o fantasma da senhora não se comunicaram com ninguém, as fadas nem sequer apareceram para os mortais e a senhora na escada só olhava para a menina, não falando com ela. Embora a menina estivesse muito assustada, se o fantasma fosse mesmo de sua falecida babá, não era uma pessoa má em vida. Já o fantasma do cemitério, ao reivindicar que fosse enterrado ao lado de uma menininha, demonstra querer continuar suas más ações mesmo depois de morto, o que torna a história de Jim ainda mais assustadora. Margaret Llewellyn-Jones sugere que Jim está preocupado com a morte iminente da mãe ou que seus desejos sexuais estão enterrados, pois embora tenha quarenta anos, ainda é obrigado a morar com a mãe, sem a possibilidade de estabelecer uma relação amorosa. (2002, p.99).

Bob Curran, no livro sobre Banshees mencionado anteriormente, ressalta a superstição de que os mortos não podem ser deixados sozinhos antes do enterro, pois caso isso aconteça, haverá discórdia ou má sorte para a família ou para a comunidade (1996, p.102). Na história de Jim, só duas ou três pessoas vieram para o velório e o corpo provavelmente ficou sozinho por algum tempo. Como confirmação desta superstição, a cena seguinte é um ligeiro desentendimento entre Finbar e Jack. Valerie pede para ir ao banheiro feminino, mas como não está 
funcionando, Brendan a leva para usar o banheiro em sua casa, deixando Jack, Finbar e Jim no bar. Finbar diz a Jim que ele não deveria ter contado a história sobre o pervertido; Jack defende Jim, e dá a entender que o próprio Finbar é quem sugeriu as histórias sobrenaturais como se fossem parte do tour; ou mesmo uma maneira de atrair os turistas usando o folclore da região. Todos concordam que quando Valerie voltar, eles deveriam contar piadas; afinal, o fato de ela estar só buscando paz deve indicar que alguma coisa aconteceu em sua vida, e que tudo pode ser mais fácil se ela se sentir bem-vinda. Jack oferece mais uma rodada, e Finbar quer saber como vai a saúde da mãe de Jim. Nesta cena, além de podermos observar uma intimidade maior entre eles, com brigas e pedido de desculpas, pode-se notar a disposição da pequena comunidade em aceitar e acolher Valerie, que ao retornar com Brendan comenta que ao ouvir tais histórias, se sente à vontade para contar o que lhe aconteceu. Observamos também que as ações como ir ao banheiro e pegar mais bebidas são recursos usados para interromper o contar de histórias, servindo como um intervalo entre uma história e a outra, o que confere tempo para que as personagens, leitores e espectadores reflitam sobre o que foi relatado e também criando uma expectativa para o que virá a seguir.

Primeiro Valerie explica que tinha um bom emprego em Dublin, que seu marido, Daniel, é professor de engenharia na Dublin City University, que tiveram uma filha chamada Niamh em 1988 e quando ela estava com cinco anos Valerie voltou a trabalhar. Acrescenta que Niamh ficava na casa da avó depois da escola até Valerie buscá-la no início da noite. Além da escola, Niamh fazia natação às quartas-feiras no CRC - Central Remedial Clinic, e gostava muito dessa atividade. Era uma menina muito esperta, já sabia os telefones de sua casa, da casa da avó e do trabalho de Valerie. O único problema era na hora de dormir, pois tinha muito medo do escuro. Niamh dizia que tinha gente na janela, no sótão, que alguém estava subindo a escada, crianças batiam na parede de seu quarto; além disso, a menina comentava que havia sempre um homem do outro lado da rua que a observava. Um de seus maiores medos era acordar na manhã seguinte numa casa totalmente vazia, sem móveis, sem a mãe e o pai. Valerie e Daniel consultaram médicos, mas todos diziam que ela estava bem, eram temores normais para a idade e que deviam só controlar o tipo de livros e programas de televisão para evitar que ela se impressionasse. Valerie sempre falava para Niamh ligar caso ficasse muito assustada durante o dia e ela iria buscá-la na casa da avó. 
Em março do ano anterior, Niamh tinha uma apresentação de natação que Valerie prometeu ver, só que como não conseguiu sair a tempo do trabalho, chegou na hora do encerramento e notou uma ambulância na porta do CRC. Quando entrou, não havia mais ninguém na piscina e reparou que um grupo de crianças estava chorando e uma professora as confortava. A mãe de uma das crianças aproximouse e contou que Niamh havia batido a cabeça na piscina, fora retirada da água e que o paramédico estava tentando ressuscitá-la. Enrolaram Niamh numa toalha e a levaram de ambulância até o hospital Beaumont, mas ela já estava morta. Durante o enterro, Valerie chegou a pensar em tirá-la do caixão e tudo acabaria bem, que nada do que estava acontecendo era real. Meses se passaram, Daniel se entregou ao trabalho e Valerie passava os dias em casa sem disposição para nada. Uma manhã, o telefone tocou várias vezes enquanto ainda estava na cama. Resolveu atender e parecia que a linha estava cruzada, pois ouvia muitas vozes sem distinguir o que diziam, então ouviu Niamh pedindo para Valerie ir buscá-la na casa da avó. Niamh estava muito assustada, pois não havia ninguém, crianças batiam na parede e um homem estava atravessando a rua para pegá-la. Só de camiseta, Valerie chorava demasiadamente no caminho até a casa da sogra, sabendo que não encontraria Niamh, mas muito assombrada, achando que a filha ainda precisava dela, embora não houvesse mais nada que ela pudesse fazer.

O que faz a história de Valerie a mais assustadora de todas não é o elemento sobrenatural, o telefonema da filha morta, mas sim o fato da história ter se passado com a própria narradora e, acima de tudo, a impossibilidade de superar a morte de uma filha. Diante de uma situação tão pessoal, as reações das personagens são diversas, como o próprio Jack diz: "Está tudo bem, nós sentados aqui, às voltas com estas histórias antigas. Mas aí, uma situação pessoal como a sua. Que aconteceu com você. As pessoas vão lidar com isso de várias maneiras." (McPHERSON, 2004b, p.64). O diálogo entre eles, logo em seguida, é entrecortado de pausas, como mostram as rubricas, as quais demonstram a dificuldade de se falar sobre uma situação tão terrível. Num primeiro momento Jack sugere a possibilidade de Valerie ter sonhado; Finbar está preocupado com o fim do casamento dela, pois sabe que Valerie irá morar sozinha na casa que acabou de comprar; Jim menciona que poderia ter sido um problema no telefone ou número errado. Depois, explicações são oferecidas para refutar a validade das histórias anteriores e finalmente Finbar se mostra solidário com a dor de Valerie: "Estou ignorando o mais importante. Eu sinto 
muito pela sua filha, Valerie, sinto muito mesmo". (McPHERSON, 2004b, p.62). Finbar e Jim decidem ir embora, Brendan entrega uma pequena garrafa de whiskey de presente para Jim. Ao se despedir de Valerie, Jim comenta que irá rezar para a menina, mas tem certeza de que ela não precisa, pois é pura e inocente. Finbar avisa que irá passar na casa de Valerie em um ou dois dias para verificar se está tudo bem. Valerie, em busca de paz e sossego, encontra também apoio, conforto e compaixão. Tanto as personagens que ouvem a história, quanto o espectador sentem, ao fim da narrativa, o que os estudiosos do teatro chamam de catarse. Segundo Patrice Pavis, catarse trata-se do efeito moral e purificador da encenação de uma tragédia clássica, cuja situação dramática, de extrema intensidade e violência, trazem à tona "os sentimentos de terror e piedade dos espectadores que se identificam com o herói trágico, proporcionando-Ihes o alívio, a purgação desses sentimentos" (2009, p.40-1). Embora The Weir não seja considerada uma tragédia clássica, o conceito de catarse se aplica, pois podemos inferir que a história de Valerie teria essa função catártica nas outras personagens, que estariam prontos para uma "limpeza da alma".

Por outro lado, o crítico Eamonn Jordan (2004) propõe uma leitura diferente e bastante intrigante para a história de Valerie. Ela poderia ter inventado sua história para vencer as personagens masculinas no próprio jogo deles. Assim, os medos, pavores e ansiedades das narrativas anteriores, reaparecem intencionalmente no relato de Valerie. Se olharmos com atenção percebe-se que existem alguns detalhes comuns entre as histórias: o que chama mais atenção é a coincidência do nome da filha de Valerie, Niamh, que é o mesmo nome da menina assombrada pela babá. Além disso, quando Finbar chega à casa dos Walsh, a menina está enrolada em um cobertor assim como a filha de Valerie vai para a ambulância enrolada numa toalha. Outro ponto em comum são as batidas nas portas na altura em que uma criança bateria na narrativa de Jack com as crianças batendo nas paredes do quarto da filha de Valerie. Ademais, na história de Finbar, a senhora Walsh bate em sua porta para pedir ajuda. O temor que Niamh sente do homem do outro lado da rua nos traz a imagem do pervertido do relato de Jim. Outra coincidência seria o fato da casa de Maura Nealon levar cinco anos para ser vendida e Valerie ter voltado a trabalhar quando Niamh fez cinco anos. Médicos são chamados para dar sedativos a Niamh Walsh e a Valerie. O telefone e a ouija board servem como meio de comunicação entre os vivos e os mortos. Além do mais, Niamh Walsh liga para mãe ir buscá-la e, 
no telefonema que Valerie recebe, a filha morta também pede para mãe buscá-la na casa da avó.

Segundo a visão proposta por Eamonn Jordan, a história de Valerie está centrada na morte de uma menininha, no luto da mãe e na incompreensão masculina deste luto, uma vez que Daniel não parece apoiar Valerie, dizendo que ela precisa aceitar a morte da filha. A personagem de Valerie está associada à trágica vítima feminina; entretanto, o papel de Valerie muda de vítima para manipuladora, o que torna a história dela ainda muito mais assustadora, pois ela teria a frieza de inventar um acontecimento terrível: a morte de uma filha. Estamos aqui diante do conceito de narrador não confiável ou suspeito, pois a credibilidade de Valerie foi seriamente comprometida devido à sua instabilidade psicológica ou mesmo à tentativa deliberada de enganar o espectador/outras personagens. Este tipo de narrador é geralmente usado para gerar suspense na história (BALDICK, 2004). Apesar da instigante leitura de Jordan, pensamos que Valerie foi verdadeira, ou melhor, ela realmente acredita que passou por algo inexplicável. Entretanto, fabricada ou não, a narrativa de Valerie cria um impacto grande nas outras personagens, levando-as a encarar a realidade de suas vidas, como comprova a última história contada por Jack.

O diálogo que a antecede, é bem mais íntimo, com perguntas pessoais que levam Valerie a perguntar se Jack já pensou em se casar algum dia. Jack conta que entre 1963 até 1966 namorou uma garota da região; eles se davam muito bem, mas ela só falava em ir para Dublin. Cansada de esperar que ele a acompanhasse, ela arrumou um emprego e mudou-se para lá esperando que ele a seguisse. Jack chegou a visitá-la algumas vezes; depois de um tempo ele deixou de responder às cartas que ela escrevia. Certo dia recebe a notícia de seu casamento; num ônibus fretado para os convidados Jack foi à cerimônia usando um terno novo, com sapatos bem polidos, mas numa incrível ressaca.

Quando viu a ex-namorada entrar na igreja, só conseguiu esboçar um sorriso, saiu, e caminhou pelas ruas de Dublin, sem coragem para ir à festa. Entrou em um bar, bebeu umas duas canecas de cerveja e o barman, percebendo que Jack não estava bem, resolveu lhe oferecer um sanduíche. Jack conta que pegou o sanduíche e começou a comer com muita dificuldade para engolir; estava a ponto de chorar, mas fez questão de comer tudo, pois alguém que ele nem sequer conhecia havia feito algo só para ele. "Uma coisa tão pequena. Mas, enorme na minha condição. 
Aquele sanduíche me fortificou como nenhuma refeição tinha feito em toda minha vida." (McPHERSON, 2004b, p.69). Sua narrativa termina quando comenta que o trabalho na garagem alivia o sentimento de arrependimento ao lembrar o que deveria ter feito; e diz que desde então, "não há manhã, sem que eu acorde pensando nela". (McPHERSON, 2004b, p.69).

A narrativa de Jack, obviamente não é uma história sobrenatural; no entanto, ele é permanentemente "assombrado" pelo fantasma da ex-namorada. Voltando à primeira história contada por Jack, em que a casa de Maura bloqueou o caminho das fadas, podemos relacionar tal imagem com o caminho que Jack bloqueou para si mesmo por falta de coragem para percorrê-lo. O sobrenatural então não está mais relacionado com coisas estranhas que podem aparecer em nossos caminhos, mas sim com o sentimento de perda e solidão que possa vir assombrar nossas vidas.

Interessante notar que quatro entre as cinco personagens que estão no bar contam histórias: Jack, a primeira e a última; Finbar a segunda, Jim narra a terceira e Valerie muda o tom com sua narrativa pessoal. Brendan, o dono do bar, se abstém; durante a peça ele serve as bebidas e ouve atentamente todas narrativas, como se estivesse desempenhando o tradicional papel do barman que é também terapeuta. Nesse sentido, o papel de Brendan pode ser relacionado ao ouvinte na dinâmica do contar histórias ou, por ser o mais jovem deles, sua vida ainda não tem assombrações para serem compartilhadas. No entanto, Brendan não é só um mero ouvinte, pois é o primeiro a defender Valerie: "ela disse que sabia o que era," (McPHERSON, 2004b, p.60), diz em tom bem agressivo para evitar que os outros continuem a questionar a veracidade da história dela. No final da peça, quando Finbar e Jim saem de cena, Brendan declara que o bar está oficialmente fechado e que agora eles estão em sua casa. Como anfitrião, propõe que cheguem mais próximo do fogo e serve mais bebidas, Valerie pergunta se ele precisa de ajuda com a arrumação dos copos e ela também acha as chaves do carro dele antes de irem embora. Através dessas ações, inferimos que desta noite irá surgir uma grande amizade entre eles e que esta pequena comunidade rural de seres solitários capazes de fornecer conforto uns aos outros, aceitou Valerie como seu mais novo membro.

Nicholas Grene (2006, p.57) ressalta a preferência de Conor McPherson para a forma de monólogo e menciona que em The Weir os monólogos são mascarados pelo ato de contar histórias no palco. Como observamos, o dramaturgo não oferece 
essas histórias isoladamente, somente como exemplos do sobrenatural irlandês; as histórias de The Weir, embora sejam o centro da peça, fluem naturalmente do diálogo das personagens, como se aparecessem acidentalmente. Assim, quando alguém está narrando sua história, é natural que as outras personagens silenciem. Contar histórias é também uma forma de socialização: quando uma boa narrativa está sendo relatada, não a interrompemos para não "quebrar o encanto". Portanto, com The Weir, McPherson consegue demonstrar que o ato de ouvir é tão importante quanto o ato de falar; afinal, a importância de se encontrar um ouvinte é crucial, especialmente para Valerie.

E contar histórias no palco é teatral? David Ball, em Para Trás e Para Frente, diz que alguma coisa é teatral "quando intensifica a atenção e envolvimento dos espectadores" (1999, p.59). Acreditamos que não só as histórias de The Weir, como também a peça em si, envolvem o espectador que sairá do teatro com muito que pensar. Fintan O'Toole (2003, p.184-5) comenta que alguns críticos de teatro usam o termo "haunting" para descrever peças que nos assombram, com imagens que permanecem em nossa mente mesmo muito tempo depois das luzes do teatro se apagarem; The Weir merece tal descrição. Na opinião de Dominic Dromgoole (2002, p.188-9), The Weir é uma das mais bem sucedidas peças dos últimos vinte anos. Ele a descreve como uma mistura fantástica, inteligente e original de diferentes tradições do teatro irlandês, com traços de J. M. Synge, Sean O'Casey, Brian Friel, Tom Murphy e Billy Roche. McPherson usa a técnica de contar histórias de uma maneira única, com humor e ritmo próprio. Em The Weir, o autor usou a tradição irlandesa de contar histórias como um meio de liberar emoções contidas e recuperar a solidariedade humana de uma comunidade, mesmo que esta esteja inserida num contexto economicamente desfavorável. Além disso, observamos que conforme as histórias são relatadas, os elementos sobrenaturais vão se aproximando mais dos narradores, aumentando também o grau de intimidade e confiança entre as personagens, culminando com a possibilidade de alívio para situações dolorosas. No teatro, o público que participa como ouvinte, também se torna parte desta comunidade temporariamente.

Em St Nicholas o relato do crítico de teatro sobre sua convivência com vampiros pode ser fruto de um colapso nervoso e as fadas e fantasmas de The Weir fazem parte das histórias trocadas entre as personagens. No entanto, na peça a seguir, The Seafarer, o sobrenatural se faz presente no palco. 


\section{CAPÍTULO 3}

\section{The Seafarer: O Fausto Contemporâneo}

In the darkest time there can still be light and hope and energy. Conor McPherson

O conjunto arqueológico neolítico de Newgrange, construído há cerca de cinco mil anos, portanto anterior ao conhecido Stonehenge na Inglaterra, é uma tumba localizada no Vale do Rio Boyne, no condado de Meath, na Irlanda. No final de um túnel de dezoito metros encontra-se uma câmara funerária que fica iluminada durante o nascer do sol do dia mais curto do ano - o solstício de inverno. A câmara foi construída de forma a permitir a passagem dos primeiros raios de sol por uma abertura por cima da entrada principal. Neste dia de inverno um fino raio de sol ilumina por pouco tempo o piso de pedras decoradas com espirais. Esta imagem inspirou Conor McPherson a escrever The Seafarer, pois mesmo no dia mais escuro do ano, um lugar tão lúgubre pode ser iluminado por alguns instantes.

A ação da peça acontece na véspera do Natal, portanto durante o inverno no hemisfério norte, e embora o início do primeiro ato se passe de manhã, o palco permanece bastante escuro durante todo o tempo. As rubricas sugerem que só uns raios de luz vindos da cozinha, da porta dos fundos e através das cortinas pesadas da janela iluminem a sala de estar. Diferentemente de The Weir que acontece num 
bar com uma atmosfera caseira, The Seafarer se passa numa casa, mais precisamente na sala de estar dos Harkin que se assemelha a um bar, cheia de objetos originalmente retirados de pubs, como por exemplo: espelhos com propagandas de cerveja ou whiskey, cinzeiros, descansos para copos e até mesmo bancos. Tais objetos sugerem que os moradores são frequentadores assíduos de bares e denunciam a ausência de um toque feminino na casa. Na segunda cena do primeiro ato já é fim de tarde, está mais frio, ouvimos o vento vindo de fora e o ambiente escurece ainda mais. No segundo ato que se passa à noite, o vento está mais forte, ouvimos a tempestade e a sala é iluminada somente por poucas lâmpadas, algumas velas e o lume vindo da lareira de ferro que fica no canto esquerdo; a peça inteira, portanto, está carregada dessa atmosfera escura que só irá se alterar nos momentos finais.

O título da peça - The Seafarer - foi retirado de um poema medieval AngloSaxão anônimo sobre a vida desolada e solitária de um marinheiro no mar, durante o inverno. McPherson insere antes de seu texto uma epígrafe deste poema, traduzido por Richard Hamer, trecho também reproduzido no programa da montagem de Londres no National Theatre:

He knows not

Who lives most easily on land, how I

Have spent my winter on the ice-cold sea

Wretched and anxious, in the paths of exile

Lacking dear friends, hung round by icicles

While hail flew past in showers...

Ao observar tal trecho, antes de ler ou assistir a peça, imaginamos quem seria a personagem tão solitária e ao final da leitura notamos que a atmosfera de isolamento percebida no poema permeia toda a peça. Em "Irish playwright Conor McPherson chases away the demons", resenha publicada em janeiro de 2009 sobre a montagem de The Seafarer em Pittsburg, Christopher Rawson ressalta que o Natal representa luz, renascimento e esperança; imagem que contrasta com a escuridão, solidão e desespero apresentados na peça. Este isolamento pode ser notado já na

\footnotetext{
*Resenha de Christopher Rawson sobre The Seafarer. Disponível em: http://www.post-gazette.com/pg/09022/943433-325.stm. Acesso em: 20/05/2009.
} 
descrição do cenário: uma casa em Baldoyle, região costeira ao norte de Dublin, considerada mais um bairro do que uma cidade, pois só possui uma igreja e alguns poucos bares e lojas no centro; portanto afastada da agitação de Dublin. As rubricas ainda mencionam que da costa pode-se avistar um morro chamado Howth Head, em irlandês Binn Eadair, que fica na península de Howth, lugar conhecido por seus mitos e lendas.

No programa da apresentação de Londres, o escritor e fotógrafo Dave Walsh descreve uma das histórias sobrenaturais da península de Howth. Proeminentes cidadãos da alta sociedade como políticos, lordes e até o xerife da cidade, eram membros de um clube chamado Hellfire onde eles se isolavam para jogar cartas apostando não só muito dinheiro, mas também cavalos, terras e mulheres. De acordo com a lenda, numa noite escura de inverno, quando ventava e chovia a cântaros, um senhor muito bem vestido bate à porta pedindo abrigo. Bem recebido pelo grupo, ele participa do jogo de cartas e mostra-se logo um jogador de muito talento até que um dos membros derruba uma carta e ao abaixar-se para pegá-la vê que os pés do recém chegado são cascos de animal, cloven hooves, a marca de Satã. Neste momento o estranho desaparece na forma de uma bola em chamas que se desintegra ao atingir o teto. Encontramos uma versão parecida desta mesma história relatada por Padraic O'Farrell no livro Irish Ghost Stories intitulada “The Devil and the Daughter of Loftus Hall". Loftus Hall seria uma mansão localizada na península Hook, no condado de Kildare, que por volta de 1731 era propriedade de Charles Tottenham, conhecido membro do parlamento irlandês da época. No relato de O'Farrell é a filha de Tottenham quem derruba as cartas e ao descobrir os pés do estranho grita: “É o Belzebu! É o Belzebu, eu juro!” (O’FARRELL, 2004, p.95) ${ }^{*}$. E o demônio, transformado numa nuvem roxa de fumaça, também desaparece ao chegar ao teto. McPherson menciona que este mito sempre o intrigou e ficava imaginando o que poderia ter acontecido depois do demônio transformar-se em fumaça. Não é difícil perceber muitos aspectos destas narrativas em The Seafarer: além do fato do demônio participar do jogo de cartas, as condições do tempo das histórias e da peça são bastante semelhantes. A ação se passa durante o inverno e como já vimos a casa dos Harkin também fica numa região bastante isolada. Outro dado intrigante apresentado nas rubricas é o fato da casa ter sido construída num

\footnotetext{
* "It's Beelzebub! It's Beelzebub, I swear it!"
} 
morro, sendo que a porta da frente fica no alto; ao chegar à casa, consequentemente, as personagens descem as escadas até a sala de estar, dandonos a impressão de que estamos em um porão. Este fato, juntamente com o nome do clube de jogadores, Hellfire Club, nos faz pensar que descer até a sala de estar seria semelhante à descida ao inferno. Aliás, o consórcio do homem com a força do mal está também presente na lenda de Fausto e em The Seafarer o primeiro ato chama-se "O Demônio em Binn Eadair", uma referência clara à visita do diabo à casa dos Harkin; o nome do segundo ato é "Música ao Sol" (McPHERSON, 2006a)*.

A lista das personagens, ao contrário de The Weir, contém os nomes completos com as respectivas idades além de uma breve informação sobre cada uma delas: James 'Sharky' Harkin, cinquenta anos, ex-pescador, ex-motorista de furgão e ex-motorista particular; Richard Harkin, sessenta anos, irmão de Sharky, ficou cego recentemente; Ivan Curry, quase cinquenta anos, velho amigo dos Harkin; Nicky Giblin, cinquenta anos, amigo de Richard e finalmente Mr Lockhart, cinquenta anos e conhecido de Nicky. Os sobrenomes Harkin, Curry e Giblin são de origem irlandesa e o sobrenome Lockhart é escocês. No entanto, ao pronunciarmos "lockhart" podemos inferir o significado de "coração trancado", que bem descreve esta personagem. Já a palavra "Sharky" geralmente é usada para uma pessoa desonesta, que costuma se envolver em brigas, fraudes ou negócios ilícitos.

Detalhes importantes sobre as personagens e a ação também são reveladas na sinopse do programa da peça. Sabemos que Sharky volta a Dublin para cuidar de seu irmão Richard, que é descrito como irascível, uma pessoa que se irrita com facilidade e observamos que Sharky durante todo o primeiro ato está tentando manter a calma diante da irritação de Richard. Um outro dado relevante é que a ação irá envolver um jogo de cartas com um estranho e Sharky estará apostando sua alma. Assim sendo, entramos em contato com um traço do sobrenatural já na sinopse da peça. Ao invés de deixar para revelar no final da história que um dos jogadores seria o diabo, como na história do Hellfire Club, McPherson fornece esta informação no fim do primeiro ato o que cria um suspense diferente, pois queremos saber o que vai acontecer com Sharky, mais precisamente com a alma dele. Podese notar uma semelhança com o que acontece em St Nicholas, no qual o fato de o

\footnotetext{
${ }^{*}$ Act one: The Devil at Binn Eadair. Act two: Music in the Sun.
} 
narrador ter convivido com vampiros também foi revelado no início do monólogo, criando o suspense em torno de como a personagem conseguiu escapar.

Sharky é o primeiro a entrar em cena descendo as escadas vestindo suéter e pijama com a parte de cima diferente da de baixo. Ele tem um pequeno curativo no nariz e alguns esparadrapos já sujos nos dedos da mão direita. Sua primeira ação é tentar acender a luz vermelha que deveria iluminar um quadro do Sagrado Coração de Jesus, dando umas batidinhas na lâmpada que só permanece acesa por poucos segundos; depois vai até o aparelho de som e observa a pequena árvore artificial de Natal; quando desliga o som, percebe que o telefone está tocando. Fala alô umas duas vezes, mas como ninguém responde, desliga e ouve Richard chamando por ele. Leva um susto ao perceber que o irmão cego havia passado a noite deitado no chão da sala. Conor McPherson *explica que já havia escrito uma peça com esta personagem (Sharky) só que não encontrou um fim adequado para a história. Nesta outra peça a personagem dizia que iria embora para visitar o irmão, então o dramaturgo decidiu que em The Seafarer, Sharky já estava na casa de Richard na véspera de Natal. Pode-se dizer, assim, que The Seafarer foi criada a partir dessa outra peça iniciada e descartada por McPherson, da narrativa The Hellfire Club e possivelmente da lenda de Fausto.

A aparência de Richard é terrível, pois está sem fazer a barba e veste um terno preto, uma camisa branca imunda, um antigo boné e um só pé de chinelo. Provavelmente está usando as mesmas roupas há muito tempo e deve ter desmaiado no chão da sala de tão bêbado. Sharky ajuda o irmão a calçar o outro pé do chinelo, acha a bengala dele e leva-o ao banheiro. Sugere que ele tome um banho, mas Richard diz que só irá tomar banho no dia seguinte, para celebrar o Natal. Enquanto Richard está no banheiro, Sharky vai até a cozinha preparar o café da manhã e volta com várias caixas pequenas de cereal Kelloggs, algumas laranjas, torradas e um bule de chá. Neste momento Ivan aparece no topo da escada dando bom dia a Sharky e perguntando se alguém viu seus óculos. Ivan também passou a noite dormindo no chão, ou melhor, no tapete de um cômodo cheio de caixas na parte de cima da casa. Ele está vestindo uma camisa barata de poliéster que está para fora das calças. De tão bêbado que estava, Ivan não se lembrava de ter

*Entrevista com Conor McPherson sobre The Seafarer. Disponível em:<http://www.thelowry.com/Shows/seafarer.html>. Acesso em: 14/01/2008 
conversado com Sharky durante a noite e repete as mesmas perguntas sobre quando este havia voltado, onde estava trabalhando e como havia machucado o nariz. Richard mostra-se preocupado quando descobre que o irmão havia brigado na cidade.

Como podemos ver através dos detalhes descritos acima, a primeira cena deste ato é bem realista e desde o início mostra Sharky tentando ajudar o irmão que, apesar de mal humorado, também demonstra preocupação com o bem estar de Sharky. O dialogo entre as três personagens revela que Sharky está há dois dias sem beber, que ganhou alguns CDs de presente de Natal da esposa de seu antigo patrão, que sua ex-esposa está morando com Nicky, que está envolvido num processo contra uma empresa de ônibus e que agora está fazendo de tudo para poder se dar bem com o irmão. Observamos também que Sharky está tentando o tempo todo se manter ocupado e quer dar um pouco de ordem no caos da casa e na vida dele e do irmão. Além disso, percebemos que Ivan tem muita dificuldade de enxergar sem seus óculos e que passa muito tempo na casa dos Harkin, dando pouca atenção a sua esposa Karen e aos filhos. Por sua vez, Richard está sempre bebendo e fica muito perturbado quando uns indigentes, também bêbados, fazem algazarra na porta dos fundos de sua casa. Este início, bastante conturbado e barulhento, é muito importante na caracterização destas três personagens e nos fornece detalhes que serão vitais para a compreensão do desenrolar da história. Para celebrar o Natal, eles decidem comprar um peru, muita cerveja e whiskey. Ivan conta que um conhecido deles, Maurice Macken, estava trabalhando na rede elétrica de uma casa e foi eletrocutado. Sobreviveu mas, no dia em que saiu do hospital, sua casa pegou fogo e ele morreu no incêndio. Ivan comenta que Maurice tinha o costume de jogar cartas em bares da região. A história contada por Ivan já prepara o leitor para a mudança que acontecerá no fim deste ato. Essa cena termina quando todos saem para fazer as compras.

No início da segunda cena do primeiro ato, Sharky também é o primeiro a descer as escadas com sacolas de compras, a maioria de bebidas, que ele leva até a cozinha. Ouvimos os sinos da igreja tocando ao fundo e Sharky reaparece para acender uma ou duas lâmpadas, as poucas luzes da árvore de Natal e novamente, sem sucesso, tenta iluminar o quadro do Sagrado Coração de Jesus. Para os católicos, este quadro simboliza todo o sacrifício e o amor de Jesus pela humanidade; dizem que Jesus abençoa as casas que honram esta imagem. $O$ fato 
da imagem não permanecer acesa talvez possa indicar uma presença maligna na casa, ou mesmo que Sharky está tentando afastar de sua vida algum mal. Sharky sobe para ajudar Richard a descer as escadas e eles entram na sala discutindo sobre o fato de Richard convidar Nicky para jogar com eles; Sharky não gostaria de receber Nicky, pois ele está agora vivendo com Eileen, sua ex-esposa; mas logo os irmãos fazem as pazes. Sharky serve uma dose de whiskey para Richard e menciona que irá acender uma vela no parapeito da janela. Este é um antigo costume irlandês datado do século XVII: as velas acesas no parapeito das janelas na noite do dia vinte e quatro de dezembro são símbolo da hospitalidade, para receber Maria e José que viajavam em busca de abrigo. Dizem que também serviam de sinal para os padres católicos: na casa onde havia velas no parapeito a missa poderia ser rezada. A celebração da missa era ilegal na Irlanda durante o período em que houve a ascensão dos protestantes, quando uma série de leis foi elaborada visando à exclusão da população católica de cargos de poder. Algumas pessoas também tinham o costume de colocar um lugar a mais na mesa caso um visitante inesperado aparecesse. Notam-se, neste ato, alguns símbolos religiosos ligados ao catolicismo: o Sagrado Coração, a vela na janela, os sinos da igreja e até mesmo a árvore de Natal.

Quando a campainha toca, Sharky e Richard discutem novamente, pois Sharky não quer atender imaginando que seja Nicky, mas acaba cedendo e sobe as escadas para abrir a porta. Ivan aparece novamente pedindo desculpas por estar lá e explica que estava voltando para casa quando um amigo Ihe ofereceu uma cerveja e ficou, pois no bar todos estavam pagando bebidas para celebrar o Natal. Quando finalmente conseguiu sair, encontrou sua esposa Karen que voltava do correio; muito nervosa, ela nem o deixou entrar em casa para pegar o par de óculos extra. Ivan comenta que está chateado porque as crianças presenciaram a briga. Richard sugere que ele tome mais um copo de cerveja e Sharky sai para preparar alguma coisa para eles comerem. Observa-se que as soluções propostas para os problemas envolvem beber mais e esperar que eles se resolvam por si só; em nenhum momento Ivan ou Richard fazem algo para realmente mudar a situação. Sharky parece ser o único que está decidido a mudar, procura alimentar o irmão e o amigo, não aceita nada alcoólico e faz o máximo para evitar brigas com Richard.

A campainha toca novamente, Richard pede para Ivan abrir a porta enquanto ele cantarola uma música sobre o tempo assustador lá fora, muito escuro com 
trovões e relâmpagos.* Ao cantar tal música, parece que Richard tem um pressentimento do que virá a seguir. Está completamente escuro lá fora e Ivan desce as escadas trazendo Nicky e o senhor Lockhart; Richard treme como se ele sentisse um arrepio, um frio na espinha. Assim como na história do Hellfire Club, Lockhart chega muito bem vestido, num terno escuro de três peças: calças, paletó e colete. O ator Ron Cook, que atuou como Lockhart na apresentação de Londres, comentou que ensaiava usando terno completo e gravata buscando uma maior ligação possível com a personagem, além de se acostumar com o desconforto próprio da roupa. Depois das apresentações, Lockhart aceita uma dose de whiskey e Richard conta sobre a queda que o fez perder a visão, comentando que este será o seu primeiro Natal no escuro. Lockhart menciona que Richard tem uma aura muito luminosa e Richard explica que faz suas orações. Mais uma vez, observa-se a oposição luz e escuridão; este ambiente de penumbra é essencial para manter a atmosfera lúgubre da peça. Neste momento, Nicky conta que ele e Lockhart estiveram em vários bares o dia inteiro e que o novo amigo não o deixou pagar nem uma vez, ele diz que assim que as cantorias de Natal começavam, se encaminhavam para outro lugar. Todos brindam às novas e velhas amizades e a um feliz Natal. Sharky volta da cozinha, cumprimenta Nicky por educação, apesar de não querer ver o homem que agora vive com sua ex-mulher, e ao dar a mão para Lockhart, fica imaginando de onde o conhece.

Nicky avisa Ivan que viu alguns arruaceiros sentados no capô do carro dele. Ivan, Richard e Nicky saem para verificar o que aconteceu, deixando Sharky e Lockhart sozinhos. Estes arruaceiros que tanto irritam Richard servem como recurso para deixar Lockhart e Sharky sozinhos no palco; assim, as outras personagens nunca presenciam o que Lockhart diz a Sharky. Lockhart se diz surpreso por Sharky não saber o que ele está fazendo em sua casa; fala que há vinte cinco anos eles fizeram um trato e que agora ele veio buscar a alma de Sharky. Este se ajoelha no chão como se estivesse sentindo uma dor terrível, em agonia física e emocional, enquanto Lockhart se apresenta:

LOCKHART. I'm the son of the morning, Sharky. I'm the snake in the garden. I've come here for your soul this Christmas, and I've been looking for you all fucking day! We made a deal. We played cards for your freedom and you

\footnotetext{
* "Oh the weather outside is frightening, it's dark and there's thunder and lightning..."
} 
promised me, you promised me, the chance to play with you again. So don't start messing me about now... Because we're gonna play for your soul and I'm gonna win and you're coming through the old hole in the wall with me tonight. Now get up.

A partir daí instala-se o fantástico, pois o senhor Lockhart se autodenomina the son of the morning, a estrela da manhã, ou Lúcifer, um dos muitos nomes para o demônio. Ao ver Sharky chorando silenciosamente, Lockhart grita e avança como se fosse esmurrá-lo e ordena que ele não faça como Maurice Macken, aludindo à história que Ivan havia contado no início da peça. Neste instante os outros voltam contando como se livraram dos arruaceiros, Richard explica que eles estão tão bêbados que confundem os seus berros com o grito da banshee, fada solitária da tradição popular irlandesa, capaz de prever a morte de um membro da família ou alguma pessoa bem próxima que ao aparecer aos vivos, solta um grito horripilante, como vimos no segundo capítulo. Todos se servem de mais bebida e eles preparam a mesa para dar início ao jogo de pôquer.

Neste momento é importante lembrar o conceito de suspension of disbelief (suspensão voluntária da descrença), termo cunhado por Samuel Taylor Coleridge em 1817 para explicar o acordo que existe entre o criador de uma obra e seu público, e que permite a este público manter a mente aberta e mergulhar na obra que lhe é apresentada, ou seja, a capacidade de deixarmos de lado, ainda que temporariamente, nossa realidade, o mundo em que vivemos, para entrarmos no mundo que o autor coloca à nossa frente, aproveitando o que foi criado para nosso próprio entretenimento e prazer. Ao lermos ou assistirmos The Seafarer, participamos deste acordo tácito com o dramaturgo para entrar no mundo de Sharky e aceitamos momentaneamente que o demônio possa vir jogar cartas pela alma de Sharky.

Deste modo, em The Seafarer, o sobrenatural é uma presença física no palco; ou seja, o fantástico está inserido naquilo que consideraríamos real. Tzvetan Todorov, em Introdução à Literatura Fantástica, define o termo fantástico como "a hesitação experimentada por um ser que só conhece as leis naturais, em face de um acontecimento aparentemente sobrenatural" (2004, p.31). Para Todorov, o fantástico seria um gênero vizinho ao maravilhoso; a diferença é que o sobrenatural, no maravilhoso, não provoca reações particulares no leitor ou nas personagens, é 
aceito com naturalidade, como no caso dos contos de fadas, onde lobos falam e princesas dormem cem anos. Todorov subdivide esses gêneros em quatro subgêneros: primeiro o estranho-puro em que os fatos são inusitados e inquietantes, mas acabam sendo explicados racionalmente, pois as leis da natureza continuam válidas; o segundo é o fantástico-estranho, onde o leitor e a personagem só irão receber explicação racional no final da obra e podem hesitar entre aceitá-la ou não; o terceiro ele chama de fantástico-maravilhoso, quando o sobrenatural se instala e não há uma explicação racional; o quarto subgênero é o maravilhoso-puro, onde o sobrenatural é aceito com naturalidade. Diante destes gêneros e subgêneros acredita-se que The Seafarer poderia se classificada como fantástico-maravilhoso, uma vez que não temos uma explicação racional para o demônio no palco jogando pela alma de uma personagem.

$\mathrm{Na}$ literatura encontramos muitos exemplos de escritores que se utilizaram da figura do demônio em seus trabalhos. Durante nossa pesquisa, lemos o conto The Demon Lover, da escritora irlandesa Elizabeth Bowen (1899 - 1973). Nesta história a personagem principal, Kathleen Drover, retorna à sua antiga casa em Londres para pegar algumas coisas que ela havia deixado quando teve que fechar a casa na ocasião dos bombardeios durante a Segunda Guerra Mundial. Kathleen Drove é uma senhora sofrida que sobreviveu às duas grandes guerras e sua volta a casa também representa uma volta ao passado. Assim que abre a porta, observa uma carta endereçada a ela na mesa do hall. A carta deixa-a ainda mais aflita, pois parece ter sido escrita pelo seu ex-noivo que morreu na primeira guerra. Além de comentários sobre seu passado, é mencionado que alguém irá encontrá-la na hora combinada. Kathleen lembra-se que havia prometido esperar o rapaz voltar da guerra, no entanto acabou se casando com o Senhor Drover. Ela arruma as coisas rapidamente e chama um táxi que parte antes mesmo que ela informe para onde quer ir. Kathleen bate no vidro para falar com o taxista e ao ver o rosto de seu exnoivo, solta um grito de terror. Na história não há uma explicação do que pode ter acontecido, mas provavelmente Kathleen Drover teve um colapso nervoso e imaginou o rosto do amante-demônio no do motorista do táxi. Mesmo assim, tal fato não explica a carta deixada em sua casa. Por sua vez, o conto de Bowen é inspirado no poema medieval anônimo, The Demon Lover, no qual uma mulher casada é seduzida por um antigo amante que volta para buscá-la. O amante é na verdade o demônio que a convence a entrar em um navio, para depois afundá-lo. Ela morre 
afogada e ambos acabam no inferno. O poema pode servir de exemplo do subgênero maravilhoso-puro, pois o sobrenatural é aceito com naturalidade. Entretanto, no conto, o leitor pode tentar explicar racionalmente o que aconteceu com a Senhora Drover ou acreditar que a carta funcionaria como uma vingança do ex-noivo por ela ter quebrado a promessa feita há vinte e cinco anos. O interessante é que a ambiguidade apresentada no conto permite diferentes interpretações, o que o torna tão rico.

O fato de só Sharky saber que Lockhart é o demônio pode ser interpretado como se ele também tivesse alucinações, pois é alcoólatra e está há dois dias sem beber. No entanto, muitos detalhes da conversa entre Richard, Sharky e Ivan no início da peça são utilizados nas falas de Lockhart, recurso usado pelo dramaturgo para dar mais crédito à personagem. Assim como nas peças analisadas anteriormente (St. Nicholas e The Weir), McPherson mais uma vez faz uso da ambiguidade, que a nosso ver torna o texto mais complexo, com múltiplas interpretações. O regresso recente de Sharky para a casa em que passou sua infância e juventude poderia representar também uma volta ao passado, como no conto de Bowen, uma reavaliação de sua vida que, ao que parece, foi tão conturbada. Como sugere o poema medieval da epígrafe da peça, estamos diante de um grupo de almas perdidas no mar da vida.

O segundo ato de The Seafarer é o jogo propriamente dito. Muitas garrafas de bebida já foram consumidas. Richard e Ivan estão jogando em parceria, pois Ivan não tem dinheiro para apostar e Richard precisa de alguém para ver as cartas. Interessante observar que Ivan continua sem seus óculos, portanto também não consegue enxergar direito. Além disso, todos estão alcoolizados, mas em diferentes estágios de embriaguês, com exceção de Sharky que se mantém sóbrio até a metade do segundo ato. Ivan oscila entre um estado eufórico, pelo fato de estar ganhando no jogo, e depressivo, quando se lembra da briga com a esposa. Nicky está perdendo, mas continua amável com os companheiros. Richard parece estar sempre alerta com o que está acontecendo, mas também alterna comentários sentimentais com insultos, principalmente dirigidos à Sharky. Até Lockhart está um tanto bêbado, filosofando sobre o significado das cartas que recebe, "Ah, um dez é como uma torre brilhante. Como o século XX. É sólido. Surge para você."” Observa-

\footnotetext{
" "Ah, a ten is like a shinning tower. It's like the Twentieth Century. It's solid. It looms at you."
} 
se que a escuridão também se faz presente de vários modos neste segundo ato: a noite está escura, a sala não tem uma boa iluminação, Richard é cego, Ivan sem óculos mal consegue ver por onde anda, esbarrando com frequência na mobília e o álcool também contribui para manter as personagens num estado nebuloso. Toda essa escuridão colabora para criar uma atmosfera propícia para aceitarmos a presença do demônio na sala dos Harkin.

Em uma resenha* sobre a montagem da peça em Nova York, Harry Haun comenta sobre os olhares que Sharky e Lockhart trocam durante a peça na presença das outras personagens. Para o crítico, McPherson cria deliberadamente uma ironia dramática com essa guerra de olhares sem palavras, pois as pessoas que poderiam ajudar Sharky, não conseguem enxergar que ele está com problemas. Ironia dramática pode ser definida como a disparidade entre a expressão e a compreensão: a ação entre Sharky e Lockhart - troca de olhares - só é entendida pela platéia e nunca pelas personagens que poderiam socorrê-lo.

O diálogo entre eles gira em torno do jogo; no entanto muito mais é dito. Além das perguntas triviais sobre o que cada um está fazendo para ganhar a vida e sobre o carro Peugeot que Nicky está dirigindo que era de Sharky quando ele estava casado com Eileen; o diálogo também revela que Ivan uma vez ganhou um barco num jogo de cartas e que este fato tem ligação com um incêndio em um hotel onde duas famílias morreram e que provavelmente foi provocado por Ivan quando ele destilava poteen ilegalmente. Notamos que é Lockhart quem inicia este assunto e os outros rapidamente mudam a direção da conversa, mesmo assim Ivan fica pensativo, pois também deve enfrentar seus demônios algum dia. Richard então conta que sonhou que estava enxergando, que a sua cegueira não passava de um sonho e que ele podia observar numa garrafa azul no parapeito da janela a presença de Deus. Tal sonho, juntamente com os comentários de Lockhart no fim do primeiro ato sobre a aura iluminada de Richard, reforça a idéia de que ele acredita em Deus. McPherson foi educado em escola católica, mas a partir da adolescência diz ter virado as costas ao catolicismo; ele utiliza diversas imagens religiosas em The Seafarer, imagens essas que parecem ter a função de reforçar a presença do sobrenatural no palco. Através da exposição de tantos símbolos religiosos, Sagrado Coração, velas, árvore de Natal, fica mais fácil aceitarmos o demônio em busca da

\footnotetext{
* The Seafarer - The Blind and the Blind-Drunk

Disponível em: <www.playbill.com/features/article/print/113513.html>. Acesso em: 19/10/2008.
} 
alma de Sharky. Na entrevista intitulada Spirits That Haunt an Irish Writer, McPherson esclarece para Nelson Pressley que a peça não tem "uma mensagem católica ou cristã. A história de The Seafarer é contada dentro de uma estrutura católica porque o Catolicismo é o misticismo dos irlandeses." * O autor acrescenta que para o diabo aparecer é imprescindível que haja uma "estrutura religiosa" na peça.

Durante o jogo Richard pede a Ivan para ligar o rádio e Lockhart diz que não suporta nenhum tipo de música, que isso para ele não passa de um barulho muito feio; este detalhe contribuiu para a caracterização de Lockhart, complementando o que Nicky havia dito sobre eles mudarem de bar assim que começavam a ouvir músicas de Natal. O jogo é também interrompido quando Nicky recebe o telefonema de Eileen querendo saber onde ele está e quando vai voltar para casa. Temos acesso só ao que Nicky está falando, mas facilmente inferimos a parte de Eillen, tal cena demonstra que a relação entre eles é bem parecida com a relação entre Ivan e a esposa. Os maridos saem para beber e jogar cartas na véspera de Natal deixando as esposas sozinhas cuidando da casa e das crianças. Muitos críticos ressaltam que o dramaturgo é capaz de retratar somente o universo masculino, não há mesmo tantas personagens femininas em suas peças - Valerie em The Weir, Mary em Dublin Carol, Margaret em Come on Over e Neasa em Shining City - porém é a partir do relacionamento que as personagens masculinas têm com suas esposas, namoradas e mães que é possível vislumbrar o universo feminino. McPherson revela que muitos homens irlandeses ainda esperam a submissão das mulheres mesmo no século XXI.

Sharky ganha cem euros numa rodada, mas o jogo é interrompido porque os arruaceiros voltam e Richard, Ivan e Nicky saem atrás deles deixando mais uma vez Sharky e Lockhart sozinhos. Desta vez Lockhart menciona que detesta os humanos, que são como flores que morrem rapidamente quando expostas à luz que entra pelas janelas. Diz que é muito velho e que já passou por milhares de vésperas de Natal e que talvez vá presenciar milhões ainda, mas mesmo assim não consegue entender a razão de Deus amar os seres humanos. Sharky pergunta o que irá

\footnotetext{
* "It's not a Catholic message or a Christian message. I think it's a pagan one. But it just happens to be in the guise of Catholicism because that's the mysticism du jour of Irish people. The Seafarer is told within what McPherson calls "a Catholic framework."

Disponível em:

<http://www.washingtonpost.com/wp-dyn/content/article/2007/11/09/AR2007110900611.html>.

Acesso em: 10/09/2008.
} 
acontecer se ele perder o jogo e Lockhart diz que quando ele perder irá para o Inferno. Sharky quer saber o que é o Inferno e Lockhart, através de um longo monólogo, explica o que é o Inferno.

LOCKHART. What's Hell? ... Well, you know, Sharky, when you're walking round and round the city and the street lights have all come on and it's cold ... your feet are like blocks of ice ... And you see all the people who seem to live in another world all snuggled up together ... and you're on your own and nobody knows who you are. ... you're trying not to drink ... you know you can't deal with the thought that someone might love you, because of all the pain you always cause. Well, that's a fraction of the self-loathing you feel in Hell, except it's worse. Because there truly is no one to love you. Not even Him. ... You're locked in a space that's smaller than a coffin. And it's lying a thousand miles down, under the bed of a vast, icy, pitch-black sea. You're buried alive in there. And it's so cold that you can feel your angry tears freezing in your eye lashes and your bones ache with deep perpetual agony and you think, "I must be going to die..." But you never die. You never even sleep...

Sharky parece pensar sobre sua vida inteira por alguns instantes e então pega a garrafa de poteen e começa a beber desesperadamente.

Vimos que para escrever The Seafarer Conor McPherson se inspirou na imagem dos raios de sol iluminando a câmara funerária de Newgrange e na narrativa conhecida como The Hellfire Club. Será que The Seafarer é também uma versão atualizada da lenda de Fausto?

No Dicionário de Mitos Literários (BRUNEL, 2005), André Dabezies explica que alguns documentos como correspondências e notas administrativas escritos entre 1480 e 1540 demonstram que Georg Faust, conhecido como Dr. Fausto, foi um astrólogo, mestre-escola, estudioso de magia, médico e charlatão que viveu na Alemanha. Segundo Dabezies, Dr. Fausto deve ter morrido degolado ou de outra forma bem cruel, pois sua morte impressionou muito as pessoas na época e foi atribuída ao diabo. Apareceram, então, histórias sobre seus poderes e a lenda de que Fausto tivesse associação com o demônio Mefistófeles. Por volta de 1580 uma crônica menciona que Dr. Fausto teria feito um pacto com este demônio que Ihe proporcionou poderes, mas também uma morte apavorante. Em 1587, o editor Johann Spiess publicou uma narrativa anônima que reunia algumas destas histórias 
e lendas fragmentárias chamada: Historia von Doctor Johannes Fausten, popularmente conhecida por Volkbuch ou Faustbuch. Tal narrativa fez muito sucesso, com várias edições, seguindo de outras versões e traduções para o holandês, inglês, francês, dinamarquês e tcheco. Ainda segundo Dabezies, Christopher Marlowe inspirou-se na tradução inglesa do Faustbuch para escrever a peça The Tragical History of Dr.Faustus, encenada em Londres pouco depois de 1590.

A peça de Marlowe inicia-se com a apresentação que o coro faz de Fausto, como se fosse uma tragédia grega, mostrando os bons e os maus momentos, sua ascensão e queda. O coro fala da infância, da educação recebida, do processo rápido de aprendizagem em teologia, do grau de doutor obtido e compara Fausto com Ícaro, que desejando voar mais e mais alto, contraria os conselhos do pai e aproxima-se demais do sol, suas asas feitas de cera derretem e ele cai. Esta comparação sugere que Fausto desejando superar seus limites, obteve uma ascensão e posterior queda. Seguindo a fala do coro, vem o monólogo de Fausto em seu gabinete, mostrando-nos que ele está insatisfeito com seus conhecimentos que abarcam teologia e medicina. Fausto deseja ir além e acredita que com a magia poderá igualar-se a Deus. Após consultar dois magos, Fausto decide conjurar o demônio Mefistófeles, servo de Lúcifer, e quer propor um pacto: entregar-lhe a alma em troca de vinte e quatro anos para viver na terra tendo Mefistófeles para responder todas as suas perguntas e realizar suas vontades. Assim que Mefistófeles entra em cena, Fausto ordena que se retire e mude de forma, pois é muito horrendo. Sugere que ele se transforme num velho frade franciscano, dizendo que o hábito sagrado cai bem ao diabo. Este fato acrescenta um efeito irônico à peça e também mostra que Marlowe talvez fosse avesso à religião católica, lembrando que ele vivia na Inglaterra anglicana.

Outro aspecto interessante é o dialogo entre Fausto e Mefistófeles sobre o inferno, visto que o demônio identifica o inferno com a vida terrena. Para ele o inferno fica sob o céu, não tem limites e nem está circunscrito a um só lugar, "pois, onde estamos inferno é, e sempre aí estaremos" (MARLOWE, 2006, p.68). Mefistófeles acrescenta que se sente atormentado como em dez mil infernos, porque já provou das alegrias do céu e está privado da felicidade eterna. Em The Seafarer, na descrição de Lockhart, o inferno é se sentir trancado num espaço menor do que um caixão, como se estivesse enterrado vivo no mar a milhas de profundidade e 
sentisse tanto frio que as lágrimas de raiva e comiseração congelam nos cílios antes de cair, a dor nos ossos é o mesmo que uma agonia perpétua porque nunca morremos e nem sequer dormimos. No inferno ninguém nos ama, nem mesmo Deus; estamos completamente sozinhos e conscientes desta solidão sem fim. McPherson esclarece que procurou descrever o inferno de uma maneira genuinamente assustadora e a sensação de estar preso em espaços pequenos o apavora muito mais do que o fogo que é comumente usado como imagem do inferno:

I just tried to think of something that was genuinely scary. I just thought that being locked in a tiny little space like that is I don't know instinctively felt scary, more scary than the idea of just hell, is just fire and all that. ${ }^{*}$

A descrição de Lockhart complementa o inferno de Mefistófeles, uma vez que a imagem de total solidão consegue assombrar qualquer um de nós na vida terrena. McPherson partiu da identificação do inferno com a vida terrena de Marlowe para descrever um inferno facilmente reconhecível por muitos de nós; o que o torna ainda mais aterrorizante. Lockhart descreve a vida no céu como inacreditável, onde todos estão numa paz infinita e uma música vinda da luz do sol parece vibrar em todas as almas. Assim como Mefistófeles, Lockhart também sente não poder usufruir das alegrias do céu. Possivelmente Lockhart foi inspirado no Mefistófeles de Marlowe, visto como a idéia de céu e inferno de Mefistófeles é incorporada a descrição de Lockhart. Além disso, a imagem de estar enterrado vivo no fundo do mar nos remete ao poema citado na epígrafe da peça onde o marinheiro passa o inverno sozinho no mar frio como o gelo. Para construir Lockhart, McPherson entrelaça o poema medieval e a história sobrenatural The Hellfire Club com The Tragical History of Dr.Faustus de Marlowe. Provavelmente Lockhart, o demônio contemporâneo, também é solitário e deseja estar com os seres humanos só pelo contato em si e assim como Sharky, também está cansado de destruir tudo o que toca.

Kera Stevens e Munira Mutran concluem no livro O Teatro Inglês da Idade Média até Shakespeare, que o Fausto de Marlowe "em conflito entre o bem e o mal, conscientemente escolhe o mal, levado pela vontade de transcender as limitações

\footnotetext{
* Entrevista com Conor McPherson sobre The Seafarer. Disponível em: $<$ http://www.thelowry.com/Shows/seafarer.html>. Acesso em: 14/01/2008.
} 
humanas. Sua aspiração é alcançar o saber absoluto, o que o faria semelhante a Deus. Em seu orgulho e rebeldia, ele é como Lúcifer, e tal como Lúcifer seu destino é o Inferno" (1988, p.81). O inferno também parece ser o destino de Sharky.

A lenda do Dr. Fausto sobre o pacto com o demônio seduziu tanto a imaginação popular que foi re-escrita nos séculos XVII e XVIII em forma de peças apresentadas em feiras, teatro de marionetes e canções. André Dabezeis elucida que entre 1760 e 1791 houve o que ele chama de transfiguração romântica da personagem - jovens poetas, precursores do romantismo, consagram um novo tipo de Fausto - "um titã em revolta contra este mundo malfeito" (BRUNEL, 2005, p.336). Fausto se transforma num individualista audacioso que desafia a moralidade, a sociedade, a religião, e conclui uma aliança com o diabo. Em 1775, é encenado o drama de P. Weidmann, Johann Faust, ein alle gorisches Drama, em que a personagem central, Fausto, alcança a salvação pela primeira vez.

Em 1808, Johann Wolfgang Goethe publica o drama Faust, der Tragödie erster Teil também conhecido como Primeiro Fausto, porque somente em 1832, aos oitenta e três anos, alguns meses antes de morrer, Goethe termina seu Segundo Fausto. Goethe por sua vez inspirou-se no Fausto de Marlowe para escrever sua obra prima. No primeiro Fausto há um diálogo entre Deus e Mefistófeles. Enquanto Deus elogia Fausto, Mefistófeles pede permissão para tentá-lo, dizendo que Fausto não resistirá. Deus, confiante na natureza humana faz uma aposta com o demônio: ele não conseguirá desviar Fausto para o prazer, para a satisfação, ou seja, para o mal.

O Fausto de Goethe também está decepcionado com as limitações do conhecimento oferecido por seu tempo e tem vontade de superar tais limites em busca de um saber pleno, quer conhecer os mistérios da terra e do céu, não deixando de se sentir atraído pelos prazeres e bens terrenos. Fausto encontra um cão que se transforma em Mefistófeles, um demônio de aparência humana que lhe propõe o pacto: proporcionar-lhe todos os prazeres e desejos em troca de sua alma. $\mathrm{Na}$ história, Fausto conquista o amor de Margarida, uma jovem de quinze anos, porém uma série de desgraças acontece, levando-a à morte. Na segunda parte, Fausto passa por diversas experiências até fundar um império colonizando um litoral pantanoso. Acreditando ter encontrado a satisfação perfeita morre e sua alma escapa de Mefistófeles, pois os anjos levam Fausto para o céu. Não se sabe se a 
salvação de Fausto deu-se por suas nobres aspirações, pela graça divina, ou pelo amor de Margarida, que havia sido recebida no céu.

Para Marshall Berman (1982), em Tudo que é Sólido Desmancha no Ar, o Fausto de Goethe representa a tragédia do desenvolvimento. Berman divide a obra em três grandes partes, que ele chama de metamorfoses: primeiro Fausto aparece como um sonhador, na segunda, graças à mediação de Mefistófeles, Fausto entrelaça sua vida na vida de outra pessoa, Margarida, e aprende a amar e, finalmente na terceira parte, bem depois da tragédia do amor, ele conecta suas aspirações pessoais com as forças econômicas, políticas e sociais que dirigem o mundo; nesta fase Fausto aprende a construir e a destruir. Ainda segundo Berman, o demônio de Goethe, por ser oportunista, egoísta e sem escrúpulos, ajusta-se perfeitamente a imagem do empresário capitalista que se originou durante a expansão industrial vivida na Inglaterra a partir de 1760. Mefistófeles, com frequência, mostra as oportunidades de fazer dinheiro nos esquemas de desenvolvimento de Fausto. Entretanto Fausto, com seus projetos, não visa mais seu próprio e imediato benefício e sim o futuro da humanidade. Fausto então representaria um líder capaz de satisfazer a persistente necessidade de desenvolvimento aventureiro do homem moderno. Em Goethe também existe a dualidade entre o bem e o mal; ao fazer o pacto com Mefistófeles, Fausto usa seu livre-arbítrio, o herói deve ser tentado para que possa depois de errar, visualizar o caminho correto.

Em The Seafarer, Sharky não busca igualar-se a Deus como o Fausto de Marlowe e nem suprir a necessidade de desenvolvimento do Fausto de Goethe. Não podemos ver Sharky como o herói corrompido pelas forças do mal e nem mesmo como o Fausto romântico de Goethe. Sharky, o Fausto contemporâneo, aposta sua alma num jogo de cartas com o demônio para escapar da prisão. Ganha vinte e cinco anos de liberdade e promete uma revanche a Lockhart, o Mefistófeles contemporâneo. Em Marlowe, Fausto assina o acordo com Mefistófeles com seu próprio sangue em um pergaminho, cena que retrata sua dúvida na decisão entre o bem e o mal. Sharky praticamente nem se lembra de seu acordo verbal com Lockhart e aparentemente durante o período em liberdade não construiu nada de bom, tanto em sua vida profissional quanto em sua vida amorosa. Não corresponde à imagem do herói grandioso, modelo para a humanidade. Agora, vinte e cinco anos depois, é chegada a hora da revanche e Sharky, voltando para cuidar do irmão 
cego, parece querer finalmente assumir responsabilidades. Resta saber se irá conseguir mudar de atitude. Tudo indica que não, que seu lugar será o inferno descrito por Lockhart. McPherson usa o recurso do suspense para deixar a peça mais intensa, pois todos conhecem a história do pacto, mas o fim não é sempre o mesmo.

Quando Richard e os outros voltam ao palco, Sharky já está bêbado e Lockhart comenta que Sharky está tentando matar a dor. Richard diz que embora o irmão tenha o dom oposto de Midas, acredita que ele é capaz de mudar, que tem potencial. Sharky revela que irá embora durante a noite e que nunca mais irá voltar. Nicky tenta controlar a fúria de Sharky, mas também não escapa de seus comentários maldosos. Os dois iniciam uma luta e Ivan consegue separá-los levando Sharky para a cozinha. Richard explica que Sharky fica muito violento quando bebe, mas que tudo irá ficar bem em alguns instantes. Quando Sharky volta mais calmo, Lockhart propõe uma partida final para terminar a noite como amigos. Lockhart embaralha as cartas como profissional, passa o monte para Sharky cortar e depois distribui entre os jogadores que fazem suas apostas. É uma partida muito tensa, tudo indica que Sharky irá ganhar, pois ele tem uma quadra de oito, Ivan e Richard têm uma quadra de quatro e Nicky desiste porque as apostas estão muito altas para ele. No entanto, Lockhart vence a partida com uma quadra de dez. Sharky e Lockhart combinam de ir até o caixa eletrônico - hole in the wall ${ }^{*}$ - para pegar o dinheiro, Richard tenta fazer Sharky ficar, dizendo que tem como emprestar o que deve para Lockhart. Quando todos estão de saída, Ivan acha os óculos e pegando suas cartas sobre a mesa descobre que não era uma quadra de quatro e sim de ases. Sendo assim, ele e Richard venceram o jogo. Lockhart perde mais uma vez e Sharky está salvo. Antes de ir embora Lockhart diz a Sharky que alguém lá de cima gosta muito dele; nesse instante surpreendentemente acende-se a luz do Sagrado Coração de Jesus. A luz entra na sala e na vida dos Harkin quando Lockhart abre a porta para ir embora.

Richard pede a Sharky que vá até a árvore de Natal e pegue os dois presentes que estão lá, um é para Ivan e o outro para Sharky. Richard havia comprado para ele um telefone celular para que eles possam manter contato sempre que for necessário. Além disso, Richard decide vestir uma camisa limpa e pede para

\footnotetext{
* Hole in the wall também representa a entrada para o inferno, além de ser uma gíria para os caixas de banco eletrônicos dispostos nas ruas. Em português perdemos a duplicidade de significados.
} 
Ivan ajudá-lo a se barbear enquanto Sharky prepara chá com torradas para o café da manhã. Os três decidem ir para a missa depois da refeição. Richard está feliz por terem vencido Lockhart e comenta que sentiu um cheiro estranho vindo dele. Embora não fale qual é o cheiro, imaginamos que talvez seja enxofre, o cheiro atribuído ao diabo. Todas essas ações: o abrir dos presentes de Natal, o trocar de roupa, o tomar café da manhã, e a ida juntos a missa podem representar um recomeço, uma mudança, enfim, uma chance de terem uma vida melhor no futuro. Em seguida, Ivan pega os CDs que Sharky ganhou da esposa de seu ex-patrão e comenta que são músicas muito boas do sul da Irlanda, Sharky sugere que Ivan escolha um deles para tocar enquanto eles terminam de se arrumar e Ivan põe a música Sweet Little Mystery de John Martyn, cantor e compositor de Folk music. Ivan sobe para ajudar Richard nas escadas e Sharky, só no palco, retira do bolso o cartão que ele havia recebido no primeiro ato e fica parado lendo por alguns instantes enquanto ouvimos o seguinte refrão da música:

Just that sweet little mystery that breaks my heart
Just that sweet little mystery makes me cry
O that sweet little mystery that's in your heart
It's just that sweet little mystery that makes me try.

Neste momento um raio de sol muito brilhante entra iluminando a sala inteira enquanto a música vai diminuindo, o que nos lembra o título do segundo ato, "Música ao Sol". Voltando à epígrafe deste capítulo, mesmo nos momentos mais sombrios, é possível encontrar luz e esperança.

Assim como no Fausto de Goethe, Sharky não irá para o inferno, só que ainda não alcançou o paraíso. Segundo Jerusa Pires Ferreira (1995), em Fausto no Horizonte, há sempre um Fausto vindo à tona porque o tema do doutor pactário abre espaço para diversas possibilidades. Para ela, o Fausto de Marlowe seria o Fausto da danação, o triunfo da repressão religiosa: ao escolher o mal conscientemente e mesmo se arrependendo no último instante, Fausto não merece a salvação. O Fausto de Goethe seria o Fausto da salvação, onde o demônio é que sai perdendo, 
pois os anjos levam Fausto para o céu. Existem outros "Faustos" em que o demônio é logrado*.

Em The Seafarer, pela segunda vez, Lockhart não consegue levar a alma de Sharky, cuja salvação se dá pelo triunfo de Richard/Ivan sobre Lockhart no jogo, representando o que o próprio Lockhart já havia vislumbrado - a aura luminosa de Richard- a vitória do Bem sobre o Mal.

Ao utilizar-se da trama básica do homem tentado pelo demônio, disposto a pagar com sua própria vida a realização de seus desejos na terra, McPherson reescreve a história dos "Faustos" no seu texto. Observamos que não existe uma correspondência literal de cenas e detalhes entre The Seafarer com o Fausto de Marlowe nem com o de Goethe; encontramos algumas semelhanças e muitas diferenças mesmo na aproximação das personagens principais: Mefistófeles com Lockhart e Fausto com Sharky. Tal re-escritura nos remete ao conceito de intertextualidade sugerido por Julia Kristeva: "todo texto se constrói como mosaico de citações, todo texto é absorção e transformação de outro texto" (KRISTEVA, apud NITRINI, 2000, 161). Para Leyla Perrone-Moisés, “entende-se por intertextualidade este trabalho constante de cada texto com relação aos outros, esse imenso e incessante diálogo entre obras que constitui a literatura. Cada obra surge como uma nova voz (ou um novo conjunto de vozes) que fará soar diferentemente as vozes anteriores, arrancando-lhes novas entonações" (2005, p.68). Há intertextualidade foi discutida por Sandra Nitrini que define três elementos importantes a serem considerados para se estudar algum tipo de re-escritura: "o intertexto (o novo texto), o enunciado estranho que foi incorporado e o texto de onde este último foi extraído" (2000, p.164).

Outros críticos escreveram sobre este processo como Affonso Romano de Sant'Anna, que afirma que falar de intertextualidade das diferenças é falar de paródia e falar da intertextualidade das semelhanças é falar de paráfrase (2004, p.28). Na paródia, para Sant'Anna, ocorre um distanciamento do texto original com o efeito de inverter o sentido: seria a repetição com distância crítica, que marca a

\footnotetext{
* Segundo Maureen Murphy, o conto The Three Wishes, de W. Carleton, incluído no livro Irish Fairy and Folk Tales, organizado por W.B.Yeats, é um exemplo de como no folclore irlandês há tratamentos do mesmo tema, mas de forma humorística. Neste conto o ferreiro Billy Dawson faz um pacto com o demônio que lhe concede três objetos mágicos: uma poltrona que faz com que as pessoas fiquem presas ao sentar, um martelo que só pode ser largado com a permissão de Billy e uma bolsa, onde tudo o que for colocado só poderá ser retirado pelo dono. Toda vez em que tenta cobrar o pacto, o demônio é enganado, ficando preso aos objetos até que Billy receba mais dinheiro.
} 
diferença em vez da semelhança. "A paródia mata o texto-pai em busca da diferença" (SANT'ANNA, 2004, p.32). A paráfrase, ainda segundo Sant'Anna, é o "grau mínimo de alteração do texto, usando a citação ou a transcrição direta de parte do texto original, assim abrindo mão de sua voz para deixar falar a voz do outro" (2004, p.29).

Não vemos The Seafarer como uma paráfrase de nenhum dos Faustos mencionados, pois McPherson não se utiliza de citações diretas para compor seu Fausto contemporâneo. Sharky está longe de ser o médico, teólogo, físico que descontente com as limitações do ser humano, almeja assimilar toda a sabedoria do mundo como o Fausto de Marlowe. O Fausto de McPherson não tem nem uma profissão definida, trabalhou como pescador e motorista de furgão, profissões pouco valorizadas perante a sociedade. Abandonou ou foi despedido do último emprego, onde era motorista particular de uma mulher casada por quem se apaixonou. O tema do amor impossível que aparece em Goethe também não chega a ser tratado com profundidade pelo dramaturgo. Quando aceitou o pacto, Sharky não buscava o conhecimento pleno do mundo, e aposta sua alma em vez de negociá-la, possivelmente sugerindo que Sharky levava sua vida como se fosse um jogo; não via a vida como um caminho de aprendizagem e evolução onde os "Faustos" são responsáveis pelas suas decisões. No entanto, não acreditamos que esta inversão de significados seja suficiente para caracterizar a peça como uma paródia do texto de Marlowe ou de Goethe. McPherson emprega elementos destes textos, que são universais, para construir o seu Fausto como na imagem do mosaico sugerida por Julia Kristeva, as múltiplas fontes compõem uma nova voz.

A lenda de Fausto foi re-escrita em diversos momentos e por muitos autores, mas porque McPherson volta a valer-se desta personagem na Irlanda do século XXI? Segundo Carmen Kuhling e Kieran Keohane (2007), em Cosmopolitan Ireland, a Irlanda está atravessando um período de transformação econômica e cultural bastante intenso. Entre 1991 e 2003 a economia irlandesa cresceu em média 6.8\% anualmente, atingindo o pico de 11.1\% em 1999. Em 1994 o termo Celtic Tiger aparece pela primeira vez e a Irlanda chega a ser considerada um dos países mais ricos do mundo. Juntamente com este crescimento econômico, houve uma internacionalização do país com a crescente exportação de talentos locais que, de certa forma, também contribuíram para a chamada globalização da Irlanda. Contudo, esta globalização da economia irlandesa trouxe consequências sociais. O aumento 
do padrão de vida acarreta um exagerado individualismo e materialismo, que entram em choque com valores tradicionais como a idéia de solidariedade pregada em tempos de crise econômica. Houve também um aumento significante na desigualdade e na exclusão social, pois a Irlanda passa a conviver com imigrantes em busca de emprego e ascensão financeira. Depressão, alcoolismo e suicídio são bastante frequentes demonstrando que uma boa qualidade de vida não é acessível para toda a sociedade irlandesa contemporânea.

The experience of living in contemporary Ireland is that of living in an inbetween world, in-between cultures and identities, an experience of liminality. This liquidity of old and new, however, and the recent experience of accelerated modernisation involve both continuity and change, and therefore new versions of Irish identity involve both glacial and accelerated time simultaneously, and invoke notions, simultaneously, of what one might call the coexistence of both discourses of tradition and modernity in Ireland.

(KUHLING \& KEOHANE, 2007, 14)

O Fausto da Irlanda contemporânea está em crise existencial e refugia-se no alcoolismo, mesmo sabendo não ser esta a solução para enfrentar seus demônios. Sharky convive neste "in-between world", trabalha para pessoas que atingiram uma realização econômica, mas ele mesmo não alcançou realização profissional nem emocional. A volta para a casa do irmão poderia representar uma busca de alento, uma forma de aplacar suas dores; mesmo vindo de uma família desestruturada, longe da estabilidade pregada pelos valores tradicionais. Apostar a alma para se livrar da prisão, também poderia representar o desejo de livrar-se da sórdida realidade do dia a dia da vida.

Em The Seafarer o sobrenatural está convivendo com o real, o demônio está entre os humanos bebendo e jogando cartas, mas a realidade da condição humana retratada na peça consegue ser mais assustadora do que enfrentar o diabo. Acreditamos que o sobrenatural foi utilizado pelo dramaturgo para chamar a atenção do público para um tema tão deprimente e recorrente como a solidão humana; e o fato de Sharky não ter perdido sua alma no jogo, coloca-o bem mais próximo de ser um "Fausto da salvação", mostrando que McPherson acredita na humanidade, 
acredita que as pessoas possam mudar para melhor e que um ser humano possa aliviar a solidão do outro.

Embora ainda não exista nenhum artigo publicado sobre The Seafarer até o presente momento, acreditamos que esta peça foi a mais bem recebida pela crítica, houve muitas resenhas cheias de elogios para o texto, para a direção de Conor McPherson e para atuação de alguns dos atores nas diversas montagens.

Since his debut on the Irish theatre scene over a decade and a half ago, Conor McPherson has carved a niche for himself as a clever and imaginative writer who specialises in imperilled souls and men-on-the-edge. The Seafarer might take these concepts more literally than most, but with a fantastic script and timeless theme, it's no wonder the playing has been brewing up a storm of rave reviews since it debuted in London last year.* (Resenha da premiere em maio de 2008 no Abbey Theatre em Dublin)

A menção ao tema de The Seafarer como atemporal também nos lembra que Sharky pode ser um Fausto contemporâneo em qualquer lugar, não só na Irlanda, pois afinal os sentimentos retratados por esta personagem são universais.

*Resenha sobre The Seafarer. Disponível em: <http://www.dublinks.com/index.cfm/loc/1/pt/0/spid/718E6E13-C1A1-65F5-B4958EB880351C6E.htm> Acesso em: 09/06/2008. 


\title{
CONSIDERAÇÕES FINAIS
}

\author{
About 50 years ago, a journalist asked an old \\ woman in the West of Ireland if she believed \\ in fairies. 'I do not, sir,' she replied, 'but \\ they're there'. \\ Fintan O'Toole
}

A partir da análise crítica das peças St Nicholas, The Weir e The Seafarer de Conor McPherson, procuramos mostrar como e porque o dramaturgo utiliza 0 sobrenatural tão largamente em sua obra. As personagens de McPherson não acreditam em fadas, fantasmas, demônio ou na vida após a morte, mas também não conseguem se desvencilhar do sentimento de que existe algo mais; assim como a velha senhora do oeste da Irlanda respondeu ao jornalista, ninguém conhece as fronteiras entre o mundo natural e o sobrenatural. Algumas pessoas acreditam que o mundo está repleto de espíritos a nossa volta, e não faltam relatos sobre assombrações, acontecimentos sinistros ou outros fenômenos ligados ao sobrenatural. Acreditar no mundo invisível está relacionado ao medo que sentimos diante do desconhecido: esse medo é uma das mais fortes e antigas emoções da humanidade, e de certa maneira, explica a popularidade das histórias sobrenaturais. Ao empregar elementos do sobrenatural em sua obra, McPherson nos faz refletir sobre as angústias do homem contemporâneo. 
Como foi demonstrado ao longo deste trabalho, o dramaturgo utiliza-se de diferentes aspectos do sobrenatural em suas peças. Em St Nicholas, ele faz uso das histórias de vampiros da tradição irlandesa para retratar um crítico de teatro e seu temor de que o tempo passou sem que ele tenha criado nada. Em The Weir, o sobrenatural está nas histórias de fadas e fantasmas inspiradas na tradição oral irlandesa dos contadores de histórias - o seanchaí ou seanachai - para mostrar o efeito destes relatos nas personagens que ao final da peça revelam tragédias pessoais há muito tempo contidas. O sobrenatural em The Seafarer é o próprio demônio em busca da alma do Fausto contemporâneo, que por sua vez procura liberdade e paz de espírito.

Ao relatar a época em que viveu na casa de William e como conseguiu escapar, o protagonista de St Nicholas está finalmente contanto uma história de sua própria autoria e de certa forma desafiando os ouvintes a acreditarem na veracidade de seu relato. Importante salientar que estamos diante de um narrador não confiável, pois desde o início de seu relato ele se coloca como um mentiroso: escreve suas resenhas antes do espetáculo terminar, mente sobre o que escreveu para se aproximar da atriz por quem se apaixonou e até questiona o público sobre a veracidade do que está sendo contado. Muito provavelmente o convívio com vampiros nem aconteceu, foi apenas um sonho, ou uma alucinação devido a um colapso nervoso. Ao que tudo indica, estamos diante de um crítico de teatro que abusava de bebidas alcoólicas e vê sua confortável existência de classe média balançada quando se apaixona por uma atriz medíocre, sofre um esgotamento nervoso e provavelmente é internado numa clínica de tratamento em Londres. O uso de vampiros é uma metáfora para as coisas que realmente nos fazem sentir medo, coisas normais que temos que enfrentar no nosso dia a dia como, por exemplo, o medo de ficar desempregado, ou questões mais amplas como o medo de envelhecer, o medo de morrer, de perder um ente querido que seja a razão de nossa existência neste mundo. Assim como o vampiro, o narrador não passava de um morto-vivo, que se alimentava da produção de outros sem ser capaz de produzir nada próprio; é depois da crise que ele faz uma auto-avaliação e renasce para uma nova vida. St Nicholas não é uma história de vampiros como os contos de Le Fanu ou o Drácula de Stoker, McPherson faz uso de elementos das histórias de vampiros em forma de paródia com o objetivo de mostrar que o crítico de teatro era, ele mesmo, uma espécie de vampiro. Obviamente o dramaturgo não acredita que todos 
os críticos tenham a mesma postura da personagem retratada na peça, mas certamente existem pessoas que vivem da mesma maneira que o protagonista; St Nicholas talvez possa servir de alerta para não cometermos o mesmo erro.

Vimos que contar histórias sempre foi parte central na cultura irlandesa, onde mitos e lendas eram passados oralmente de geração para geração, destacando assim a importância da figura dos contadores de histórias. Em The Weir, as histórias sobrenaturais são o centro da peça, como uma forma de socialização, onde as personagens desempenham ora o papel de contadores, ora o de ouvintes, e ao invés de estarem em volta da fogueira como seus antepassados, os protagonistas estão no pub em frente à lareira.

Como inspiração para as histórias sobrenaturais contadas na peça, McPherson utilizou mitos e lendas celtas relacionados ao o mundo mágico das fadas e à aparição de fantasmas. Certamente não foi o primeiro escritor que fez uso desta tradição. Antes dele, William Butler Yeats buscou registrar narrativas orais do folclore irlandês com o intuito de despertar a imaginação de leitores e escritores da Irlanda moderna. Conor McPherson não tem o mesmo objetivo que Yeats, uma vez que suas histórias têm o poder de despertar as qualidades latentes da nossa alma e, ao serem contadas, demonstram como as pessoas podem oferecer conforto umas às outras nos momentos de desolação.

Vimos que, conforme cada história é narrada, os elementos do mundo sobrenatural se aproximam mais do narrador, ao mesmo tempo em que o grau de confiança e intimidade entre as personagens vai se estreitando. Notou-se também que as histórias seguem numa certa cronologia; em The Weir, por exemplo, partem de um passado mais remoto da primeira narrativa até o relato de Valerie referente à morte recente de sua filha. Na primeira narrativa dessa mesma peça o sobrenatural está conectado ao mundo das fadas, só que elas não são vistas, apenas ouvidas; o relato nem se passa diretamente com o narrador, mas há muitos anos com uma mulher que até já havia morrido. Esta história é contada logo no início, após Valerie ser apresentada aos demais, não há intimidade entre ela e as personagens masculinas. Valerie ainda não passa de uma estranha vinda de Dublin que comprou uma casa antiga na região. Na segunda narrativa os elementos do sobrenatural são o fantasma de uma senhora vista por uma garotinha e uma presença sentida pelo narrador que o afeta tão profundamente a ponto de fazer grandes mudanças em sua própria vida. Depois deste relato, observa-se uma preocupação crescente com o 
bem-estar de Valerie, indício de que esta comunidade provavelmente irá aceitá-la. A história seguinte já se passa com o próprio narrador que, além de ter visto, fala com o fantasma de um homem, considerado pedófilo em vida. É uma história mais aterrorizante do que as anteriores e desconhecida por todos, não só por Valerie. Tal relato gera um desentendimento entre as personagens masculinas mostrando a dificuldade de ser aceito mesmo em sua própria comunidade e também preparando o leitor para a história de Valerie sobre o telefonema que recebeu de sua filha morta. Não fica claro se a menina é realmente um fantasma; aliás, a ambiguidade também está presente em todos os relatos de The Weir. Entretanto, vimos que esta narrativa teria uma função catártica nas outras personagens, levando-as a encarar seus próprios medos e culpas. A última história não é sobrenatural, mas o narrador é permanentemente "assombrado" pelo fantasma do amor perdido - não mais as aparições estranhas do "outro mundo", mas sim - a solidão, o sentimento de culpa, a perda do ente querido, enfim, tudo o que assombra nossa vida neste mundo natural. O dramaturgo sugere que as histórias de fantasmas são uma maneira que as pessoas encontraram para explicar que o sentimento que temos por alguém que se foi ainda está presente; a dor da ausência se manifesta na aparição do fantasma.

Em Come on Over (2001) e Shining City (2004), peças que não foram analisadas neste trabalho, Conor McPherson também utiliza elementos do sobrenatural. Na primeira, o elemento sobrenatural está relacionado com o fato de um jesuíta voltar para sua cidade natal para investigar um possível milagre: o corpo de uma menina intacto por mais de quatrocentos anos. O sobrenatural não se desdobra por toda a história e pode ser até explicado, uma vez que ao final da peça, sabemos que o corpo da menina já estava se deteriorando e uma explicação nos é fornecida sobre o porquê da preservação. Já em Shining City, a ação se dá no consultório do terapeuta lan, onde o paciente John relata seus problemas e explica que viu o fantasma da esposa falecida em sua casa. No fim da peça o fantasma de Mari aparece em cena revelando-se somente para o público por alguns segundos, lan está presente no palco e pressente a aparição. Acreditamos que o sobrenatural no palco de Shining City seria um recurso cênico usado pelo dramaturgo com a função de mostrar que o terapeuta também tem que aprender a lidar com seus "'fantasmas"; além disso, com o uso de tal recurso o dramaturgo surpreende a platéia, que certamente não esperava esse desfecho. Além da dor da ausência, fantasmas também podem representar o nosso elo com o irracional, o inconsciente, 
com problemas ainda não solucionados, com os nossos pensamentos e sonhos e os de nossos antepassados. Este elo é que torna o fantasma uma figura tão marcante no palco, pois o teatro é uma forma de arte que faz constantemente a ponte entre o presente e o passado, entre o mundo real e o imaginado.

Em The Seafarer presenciamos melhor o elo entre mundo natural e o sobrenatural, visto como o sobrenatural instala-se no palco, desta vez o demônio está entre os humanos conversando, bebendo e jogando cartas. Todavia, vimos que Richard, Ivan e Nicky nunca presenciam as conversas entre o Lockhart e Sharky, nem mesmo se dão conta dos olhares trocados entre estas duas personagens. Assim como em St Nicholas e The Weir, existe uma ambiguidade: Sharky, com alucinações devido à abstinência recente de álcool, pode ter imaginado que o demônio veio buscar sua alma, pois ao regressar à casa em que passou a infância e juventude, culpas passadas veem à tona e ele precisa lutar contra seus "demônios" interiores.

Para a composição de The Seafarer, o dramaturgo diz ter se inspirado na lenda irlandesa The Hellfire Club e na imagem da câmara funerária de Newgrange sendo iluminada ao nascer do sol durante o solstício de inverno. No entanto, a aproximação entre as personagens Mefistófeles com Lockhart e Fausto com Sharky foi mencionada em muitas resenhas e - ainda que não exista uma correspondência literal de cenas, detalhes e personagens entre The Seafarer e o Fausto de Marlowe ou o de Goethe - percebe-se que McPherson incorpora a história dos "Faustos" no seu texto.

Sharky, o Fausto contemporâneo, não é um herói, não busca o conhecimento pleno nem a satisfação perfeita como os Faustos anteriores e quando joga pela sua alma da primeira vez está apenas tentando se livrar da prisão. A busca pela liberdade também poderia ser simbólica, pois o ser humano nunca será completamente livre, já que, muitas vezes, nos sentimos presos à nossa rotina e obrigações. Talvez o fato de Sharky ter conseguido vinte e cinco anos de liberdade represente uma falsa liberdade pois, durante esse período ele não construiu nada, envolveu-se em brigas, não se estabilizou em nenhum emprego, separou-se da mulher e tornou-se alcoólatra. A revanche acontece justamente quando ele resolve parar de beber e voltar para cuidar do irmão cego, atos que envolvem uma responsabilidade que não parecia estar presente em sua vida até aquele momento; possivelmente seria esta a razão para que Sharky tenha merecido a salvação. 
Ironicamente, ressaltamos também que a salvação não foi conquistada pelo "herói". Sharky nem sequer vence o jogo; Lockhart perde para Richard e Ivan. O irmão, apesar de ter feito comentários desagradáveis para ele durante a peça inteira, é o responsável pela sua salvação e representa a vitória do Bem sobre o Mal.

Juntamente a Sharky, as outras personagens de The Seafarer, Richard, Ivan e Nicky retratam o homem contemporâneo que, embora viva em um país econômica e culturalmente próspero e também reconhecido internacionalmente, não alcançou esse sucesso. Eles são aqueles que foram deixados para trás por uma sociedade que passou a ser mais consumista e a valorizar mais o individualismo. Além disso, valores tradicionais, como a fé cristã, foram abalados pelos escândalos e corrupção envolvendo representantes do catolicismo. Essas personagens são pessoas presas entre dois mundos: o passado - com os valores tradicionais, que para alguns estão desacreditados - e o presente - que exige habilidades das quais eles ainda não têm domínio. Um dos únicos refúgios é o álcool, beber para "esquecer" os problemas, uma vez que o alcoolismo sempre fez parte da cultura irlandesa. Entretanto, em The Seafarer, o dramaturgo vislumbra outra saída; quando Richard diz a Sharky que acredita que ele tenha potencial e que ele ainda possa mudar para melhor, vemos que o apoio da família e dos amigos é essencial para a transformação de uma pessoa. Afinal, para que alguém consiga superar as dificuldades, é primordial que outro alguém acredite. Ao retratar o Fausto contemporâneo irlandês, McPherson também nos mostra o Fausto contemporâneo universal, pois os sentimentos e dificuldades das personagens também estão presentes nos excluídos de outras sociedades, não só da Irlanda. A nosso ver, o sobrenatural, representado pela figura do diabo encenado no palco de The Seafarer, tem a função de mostrar que o ser humano que vive no século XXI, cercado de tecnologia e inserido numa cultura onde o individualismo parece ser muito valorizado, também precisa de outro para conseguir enfrentar seus "demônios" - ele não deve seguir sozinho.

Assim como os elementos do mundo sobrenatural vão se aproximando dos contadores de histórias em The Weir, nota-se um movimento semelhante entre as peças, quando a presença do sobrenatural fica cada vez mais acentuada. Em St Nicholas, o mundo dos vampiros pertence somente ao relato do protagonista-crítico, em The Weir as histórias de fantasmas se entrelaçam uma na outra, vindo de um passado distante até chegar ao presente, e em The Seafarer o sobrenatural já está entre nós, diretamente encenado no palco. O aspecto sobrenatural permanece 
importante na obra do dramaturgo, como comprova a sinopse do seu filme mais recente - The Eclipse (setembro 2009) - ainda não lançado no Brasil. O roteiro é uma adaptação do conto Table Manners de Billy Roche publicado em Tales from Rainwater Pond em 2006, mesclado de elementos de Shining City (2004) sobre um viúvo que vê e ouve coisas estranhas em sua casa ao anoitecer e apaixona-se por uma escritora de romances sobrenaturais em visita a sua cidade para participar de um encontro literário. Igualmente, em outubro de 2009 estreou no Gate Theatre a peça The Birds, adaptação do conto homônimo de Daphne du Maurier, que também foi utilizado no roteiro do filme de terror de Alfred Hitchcock em 1963. As obras acima mencionadas também mostram que o dramaturgo participa da tendência de re-escrever obras de outros autores e que seus temas não estão restritos à Irlanda.

É preciso observar que a análise das peças partiu sempre do texto escrito, pois infelizmente não houve a possibilidade de assistirmos às montagens. Entretanto, com o auxílio das rubricas em The Weir e em The Seafarer, conseguimos imaginar o cenário, os gestos das personagens e a iluminação, aspectos importantes para a realização da peça no palco. O mesmo não se dá em St Nicholas, que possui só duas indicações cênicas: a idade do protagonista e o fato do palco estar vazio. Os cenários de The Weir e de The Seafarer são bem realistas, e criam um contraste com as histórias de fantasmas e com a presença do demônio no palco; nota-se cada vez mais acentuada a intromissão do sobrenatural na cena realista. Nas duas peças, pode-se ouvir o barulho da chuva acompanhada de ventos fortes que proporcionam uma atmosfera propícia para imaginarmos a escuridão de uma noite de inverno. Em The Seafarer a escuridão invade o palco, pois McPherson menciona o uso de pouquíssima iluminação a base de velas, algumas luzes da árvore de Natal e o fogo da lareira. A escuridão também é percebida de outras maneiras: na cegueira de Richard, no fato de Ivan perder os óculos no início e somente achá-los no final da peça e na crescente embriaguês de todas as personagens. A oposição entre luz e escuridão é um elemento essencial em The Seafarer, pois contribui para a apresentação da luta entre o Bem e o Mal e o dramaturgo usa o recurso da iluminação como uma maneira de enriquecer o conteúdo da peça.

Conor McPherson faz uso do humor em sua dramaturgia, com o provável objetivo de estabelecer contato com a platéia e também como um recurso para aliviar a tensão criada no decorrer das peças. Em St Nicholas, o humor é usado para 
salientar as diferenças entre os vampiros literários e William, como por exemplo, a referência ao alho que não tira o poder do vampiro, mas é apenas algo que ele não suporta porque causa mau hálito. É também muito engraçada a cena em que William compulsivamente conta os grãos de arroz que o protagonista derrubou na cozinha. Em The Weir, o humor fica por conta das personagens masculinas que constantemente zombam umas das outras. Outro detalhe engraçado são as inúmeras vezes que os protagonistas masculinos referem-se aos turistas como "os alemães" e ao final descobre-se que eles nem sequer sabem a nacionalidade desses turistas. O humor de The Seafarer aparece mais nos gestos e movimentos dos protagonistas que, bêbados, tropeçam e perdem seus copos quando saem para brigar com os arruaceiros. Às vezes há o humor que vem da ironia, presente no titulo de St Nicholas e em algumas falas do protagonista-crítico ou de Richard, irmão de Sharky em The Seafarer. Porém, não é um simples fazer rir; pois é através do humor que atentamos para temas mais profundos.

Em relação à forma, ressaltamos que o dramaturgo é um dos maiores representantes da tendência do uso de monólogos no teatro irlandês a partir da década de 90. Como vimos em St Nicholas, o protagonista, num palco vazio, narra sua história diretamente para a platéia, não há encenação de nenhuma parte do que está sendo relatado no palco. Já em The Weir os monólogos são mascarados pelo ato de contar histórias que igualmente não são encenadas separadamente e nem relatadas de forma isolada - elas fluem naturalmente do diálogo entre os frequentadores, o dono do bar e a recém chegada Valerie. Em The Weir, McPherson tentou a forma de diálogos ao invés de monólogo a pedido do Royal Theatre em Londres. Percebe-se que os diálogos e as ações entre as personagens no início da peça e entre as narrativas são também de cunho realista e, assim como o cenário, contrastam com o sobrenatural presente nos relatos. Além disso, gestos como pegar mais bebidas, ir ao banheiro, acender o fogo e oferecer cigarros são recursos usados pelo dramaturgo para evitar que a peça fique monótona, servindo de intervalo entre uma história e a seguinte, para que tanto as personagens quanto os espectadores possam refletir sobre o que foi relatado. O recurso de usar as ações corriqueiras para interromper o contar histórias também gera uma expectativa, um suspense para a narração que virá a seguir e, talvez possa indicar que McPherson ainda não estivesse totalmente à vontade para escrever uma peça só usando diálogos. Em Shining City, os monólogos estão previstos porque o "diálogo" se dá 
entre o paciente e o terapeuta, mas tais passagens não são tão longas quanto em The Weir. Somente em The Seafarer o dramaturgo livra-se do estigma de que só sabe escrever monólogos, pois a peça inteira é baseada em diálogos entre as cinco personagens e a única passagem em forma de monólogo é a descrição do inferno de Lockhart. Percebe-se que o monólogo foi usado de uma maneira muito eficiente, pois a definição do inferno é uma das partes mais impressionantes da peça; imaginamos que se McPherson tivesse escrito esta cena em forma de diálogo entre Lockhart e Sharky, certamente não teria a mesma força do monólogo. Ainda não tivemos acesso à re-escritura de The Birds, porém as poucas resenhas que lemos indicam que o dramaturgo também se utiliza do monólogo em algumas cenas nas quais uma personagem registra os acontecimentos em seu diário.

Depois de ter lido toda a obra de Conor McPherson, nos perguntamos qual seria sua peça mais "teatral", ou melhor, qual texto se presta bem à transposição cênica. Acreditamos que The Seafarer é a mais bem sucedida, pois, com o auxílio das rubricas tão bem detalhadas, imaginamos que a peça no palco possivelmente crie grande tensão nos espectadores. Além disso, o cenário realista em contraste com a iluminação sombria, os diversos objetos religiosos, o irmão que, apesar de tudo, também representa o Bem e o figurino das personagens retratam o dia a dia do mundo natural e ao mesmo tempo criam um contexto para que o sobrenatural se instale nessa típica atmosfera irlandesa. The Seafarer é a peça mais complexa que conhecemos do dramaturgo até agora e a que melhor retrata sua visão do mundo, visto como o autor não deixa de perceber os problemas, os temores e as angústias que afligem o homem contemporâneo, mas crê na solidariedade humana e defende valores como a compaixão, o amor e o apoio que a família tem condições de oferecer. McPherson mostra que existem similaridades até mesmo nas diferenças e a compreensão é uma virtude que anda bastante esquecida nos dias de hoje. Ficase com a impressão de que ao final da apresentação, o público sai do teatro com sentimentos edificantes. Como lembra Patrick Lonergan, em Theatre and Globalization: Irish Drama in the Celtic Tiger Era, a respeito de uma das funções da dramaturgia: "algumas peças são importantes não só porque fazem sucesso financeiramente, mas porque ajudam a mudar a maneira como as pessoas pensam" (2009, p.218). Acreditamos que The Seafarer pode ser uma dessas peças que contribuem para repensarmos algumas de nossas atitudes. 
Foi um privilégio e um prazer ter trabalhado com a obra de um autor irlandês tão brilhante e original - basta lembrar que o crítico de teatro do New York Times, Ben Brantley, o considera como "o melhor dramaturgo de sua geração". Na avaliação da dramaturgia produzida até este momento por Conor McPherson, fazemos nossas as palavras do diretor de teatro Robert Falls, que menciona não haver dúvidas de que suas peças "terão lugar entre os clássicos do teatro para as futuras gerações" (2008, p.1). Aliás, muitas peças do dramaturgo já são frequentemente re-encenadas. Em 2009 foram feitas montagens de Rum and Vodka, The Good Thief, St Nicholas, The Weir, Dublin Carol, Shining City e The Seafarer em diferentes países, como nos Estados Unidos, Canadá e Escócia. No Brasil, ainda não foi produzida nenhuma de suas peças. É preciso mencionar, porém, que The Weir, St Nicholas, Shining city e The Seafarer foram apresentadas no Ciclo de Leituras Dramáticas da Cultura Inglesa sob a direção e adaptação de Rodrigo Haddad, possivelmente uma porta aberta para futuras encenações.

Obra tão complexa certamente continuará recebendo frequente atenção de críticos e acadêmicos, pois oferece uma infinidade de interpretações e abordagens; ao examinarmos o uso dos elementos sobrenaturais em suas peças, concluímos que Conor McPherson vislumbra uma sociedade mais justa e humana. 


\section{BIBLIOGRAFIA}

ARGEL, Martha \& MOURA NETO, Humberto. O vampiro antes de Drácula. São Paulo: Aleph, 2008.

BALDICK, Chris. Oxford Concise Dictionary of Literary Terms. Oxford: OUP, 2004.

BALL, David. Para Trás e Para Frente: um guia para leitura de peças teatrais. São Paulo: Perspectiva, 1999.

BARROS, Alcides João de. O Monólogo Teatral. Tese apresentada à Escola de Comunicações e Artes da Universidade de São Paulo, não publicada, São Paulo, 1985.

BERMAN, Marshall. Tudo que é Sólido Desmancha no Ar: A Aventura da Modernidade. São Paulo: Companhia das Letras, 1986.

BERTHA, Csilla. "'That Other World': The Mythic and the Fantastic in Contemporary Irish Drama". In: STEWART, Bruce. That Other World: The Supernatural and the Fantastic in Irish Literature and its Contexts. Gerrards Cross, U.K: Colin Smythe, 1998. Vol.2

BROOKS, C. \& HEILMAN, R. B. Understanding Drama: Twelve Plays. Nova York: Holt, Rinehart and Winston, 1948.

BRUNEL, Pierre (org.). Dicionário de Mitos Literários. Rio de Janeiro: José Olympio Editora, 2005.

BYRNE, Patrick P. (org.) Irish Ghost Stories of Sheridan Le Fanu. Dublin: Mercier Press, 1997.

CARLSON, Marvin. Teorias do Teatro: Estudo histórico-crítico, dos gregos à atualidade. São Paulo: UNESP, 1997. 
CONNOLLY, Claire. (Ed). Theorizing Ireland. New York: Palgrave Macmillan, 2003.

CONNOLLY, S. J. (Ed). The Oxford Companion to Irish History. Oxford: OUP, 2004.

COSGROVE, Brian. (Ed). Literature and the Supernatural. Dublin: The Columba Press, 1996.

COULTER, Colin \& COLEMAN, Steve. (Eds.). The End of Irish History? Critical Reflections on the Celtic Tiger. Manchester \& New York: Manchester University Press, 2003.

COX, Jeffrey N. "Gothic Drama" In: MULVEY-ROBERTS, Marie (ed) The Handbook to Gothic Literature. New York: New York University Press, 1998, p.73-5.

CUMMINGS, Scott T. "Homo Fabulator: The Narrative Imperative in Conor McPherson's Plays." In: JORDAN, Eamonn, (Ed.) Theatre Stuff: Critical Essays on Contemporary Irish Theatre. Dublin: Carysfort Press, 2000, p.303-312.

CURRAN, Bob. Banshees, Beasts and Brides from the Sea: Irish Tales of the Supernatural. Belfast: Appletree Press, 1996.

DEANE, Seamus. A Short History of Irish Literature. London: Hutchinson, 1986. . (Ed.) The Field Day Anthology of Irish Writing. Vol1. Derry: Field Day Publications, 1991.

DROMGOOLE, Dominic. The Full Room: An A-Z of Contemporary Playwriting. London: Methuen, 2002.

FALLS, Robert. "Why Shining City?" In: KLEINERMAN, Lori (Ed). On stage. Chicago: Goodman Theatre Productions, 2008, vol 23 \# 2, p.1

FEIJÓ, Martin Cezar. O que é herói. São Paulo: Brasiliense, 1984. 
FERREIRA, Jerusa Pires. Fausto no Horizonte. São Paulo: EDUC HUCITEC, 1995.

FOSTER, R.F. Modern Ireland 1600 1972. London: Penguin Books, 1988. . The Oxford History of Ireland. Oxford: OUP, 1989.

FURAY, J. \& O'HANLON, R. Critical Moments: Fintan O'Toole on Modern Irish Theatre. Dublin: Carysfort Press, 2003.

GASSNER, John. Mestres do Teatro I e II. São Paulo: Perspectiva, 2002.

GREGORY, Lady. Visions and Beliefs in the West of Ireland. Great Britain: Colin Smythe, 1992.

GRENE, Nicholas. The Politics of Irish Drama: Plays in context from Boucicault to Friel. Cambridge: CUP, 1999.

. "The Spaces of Irish Drama." In: MUTRAN, Munira H. \& IZARRA, Laura P.Z. (Eds.) Kaleidoscopic views of Ireland. São Paulo: Humanitas FFLCH/USP, 2003, p.53-73.

. "Ireland in Two Minds: Martin McDonagh and Conor McPherson" In: CHAMBERS, L. \& JORDAN, E. (Eds.). The Theatre of Martin McDonagh: A World of Savage Stories. Dublin: Carysfort Press, 2006, p. 42-59.

GOETHE, J. W. Fausto. São Paulo: Martin Claret, 2007.

HUTCHEON, Linda. Uma Teoria da Paródia. Rio de Janeiro: Edições 70, 1985.

JACOBS, Joseph (org.) Mais Contos de Fadas Celtas. São Paulo: Landy, 2002.

JORDAN, Eamonn. "Pastoral Exhibits: Narrating Authenticities in Conor McPherson's The Weir." In: Irish University Review (vol.34, n.2). Dublin: ColourBooks, 2004, p.351-368.

. “Look Who's Talking, Too: The duplicitous Myth of Naïve Narrative." In: WALLACE, Clare. (Ed.) Monologues: Theatre, Performance, Subjectivity. Prague: Litteraria Pragensia, 2006, p.125-156. 
KAMM, Jürgen, ed. Twentieth-Century Theatre and Drama in English: Festschrift for Heinz Kosok on the occasion of his 65th Birthday. Wissenschaftlicher: Verlag Trier, 1999.

KEARNEY, Richard. On Stories. London: Routledge, 2002.

KENT, Brad. "McDrama: The Sentimental in Martin McDonagh's The Beauty Queen of Leenane and Conor McPherson's The Weir". In: Canadian Journal of Irish Studies. (vol. 28, n. 2 e vol. 29, n.1). Montreal: Concordia University Center, 2002/2003, p.3045.

KIBERD, Declan. The Irish Writer and The world. Cambridge: CUP, 2005.

KIRBY, P., GIBBONS, L. \& CRONIN, M. (Eds.).Reinventing Ireland: Culture, Society and the Global Economy. London: Pluto Press, 2002.

KUHLING, C. \& KEOHANE, K. Cosmopolitan Ireland: Globalisation and Quality of Life. London: Pluto Press, 2007.

LECOUTEUX, Claude. História dos Vampiros: autópsia de um mito. São Paulo: Editora UNESP, 2005.

LEHMANN, Hans-Thies. Teatro pós- dramático. São Paulo: Cosac Naify, 2007.

LLEWELLYN-JONES, Margaret. Contemporary Irish Drama and Cultural Identity. Bristol: Intellect Books, 2002.

LONERGAN, Patrick. Theatre and Globalization: Irish Drama in the Celtic Tiger Era. London: Palgrave Macmillan, 2009.

MAGALDI, Sábato. Iniciação ao Teatro. São Paulo: Editora Ática, 1986.

MAHONY, Christina Hunt. Contemporary Irish Literature: Transforming Tradition. New York: St. Marin's Press, 1998. 
MARCUS, David (Ed.). The Faber Book of Best New Irish Short Stories 2006-7. London: Faber and Faber, 2007.

MARLOWE, Christopher. A História Trágica do Doutor Fausto. Tradução e notas de A. de Oliveira Cabral. São Paulo: Hedra, 2006.

McCORMACK, W. J. "Irish Gothic and After (1820 -1945)". In: DEANE, Seamus (Ed.) The Field Day Anthology of Irish Writing vol. 2. Derry: Field Day Publications, 1991, p. 831-949.

"Irish Gothic". In: MULVEY-ROBERTS, Marie (ed) The Handbook to Gothic Literature. New York: New York University Press, 1998, p.135137.

McGRATH, Conor. \& O'MALLEY, Eoin. (Eds.). Irish Politial Studies Reader: Key Contributions. London \& New York: Routledge, 2008.

McPHERSON, Conor. I Went Down: The shooting Script. London: Nick Hern Books, 1997.

. The Weir. London: Nick Hern Books, 1998.

. McPherson: Four Plays. London: Nick Hern Books, 1999.

. Dublin Carol. London: Nick Hern Books, 2000.

. Port Authority. London: Nick Hern Books, 2001a.

. Saltwater: The shooting Script. London: Nick Hern Books,

2001b.

. The Actors: The shooting Script. London: Nick Hern Books,

2003

. Shining City. London: Nick Hern Books, 2004a.

. McPherson Plays:Two. London: Nick Hern Books, 2004b.

. The Seafarer. London: Nick Hern Books, 2006a.

. "Introduction" In: JOYCE, James. Exiles. London: Nick Hern

Books, 2006b.

MELTON, J. Gordon. O Livro dos Vampiros: A Enciclopédia dos Mortos-vivos. São Paulo: M. Books do Brasil, 2003. 
MIKAMI, H. et al (Eds.). Ireland on Stage: Beckett and after. Dublin: Carysfort Press, 2007.

MOISÉS, Massaud. Dicionário de Termos Literários. São Paulo: Cultrix, 2004.

MORASH, Christopher. A History of Irish Theatre 1601-2000. Cambridge: CUP, 2002.

MUECKE, D.C. Ironia e o Irônico. São Paulo: Perspectiva, 1995.

MURRAY, Christopher. Twentieth-Century Irish Drama: Mirror up to Nation. Manchester and New York: Manchester University Press, 1997.

MUTRAN, Munira H. Álbum de Retratos: George Moore, Oscar Wilde e William Butler Yeats no fim do século XIX: um momento cultural. São Paulo: Humanitas/ FFLCH/USP, 2002.

MULVEY-ROBERTS, Marie (Ed). The Handbook to Gothic Literature. New York: New York University Press, 1998.

NITRINI, Sandra. Literatura Comparada: história, teoria e crítica. São Paulo: EDUSP, 2000.

O'FARRELL, Padraic. Irish Ghost Stories. Dublin: Gill \& Macmillan, 2004.

OLIVEIRA Filho, Valdemar F. A Suspensão Momentânea da Ordem e Hierarquia em Drácula, de Bram Stoker. Dissertação de Mestrado, não publicada, São Paulo: USP, 2005.

O'TOOLE, Fintan. "Review of The Weir, by Conor McPherson - New York Daily news 02.04.1999." In: FURAY, J. \& O'HANLON, R. Critical Moments: Fintan O'Toole on Modern Irish Theatre. Dublin: Carysfort Press, 2003, p.184-5. 
PAVIS, Patrice. Dicionário de Teatro. São Paulo: Perspectiva,1999.

PERRONE-MOISÉS, Leyla. Texto, crítica, escritura. São Paulo: Martins Fontes, 2005.

PFISTER, Manfred. The Theory and Analysis of Drama. Cambridge: CPU, 1993.

POWER, Albert. "Bram Stoker and the tradition of Irish Supernatural Fiction". In: Dracula- Celebrating 100 years. Leslie Shepard \& Albert Power (eds.) Dublin: Mentor Press, 1997.

PRADO, Décio de Almeida. "A Personagem no Teatro" In: A Personagem de Ficção. São Paulo: Perspectiva, 1985.

ROCHE, Billy. "Table Manners" In: Tales from Rainwater Pond. Co. Kilkenny, Ireland: Pillar Press, 2006.

ROSENFELD, Anatol. O Teatro Épico. São Paulo: Perspectiva, 2002.

ROUBINE, Jean-Jacques. Introdução às grandes teorias do teatro. Rio de Janeiro: Jorge Zahar Editor, 2000.

RYNGAERT, Jean-Pierre. Introdução à Análise do Teatro. São Paulo: Martins Fontes, 1996.

SANT'ANNA, Affonso Romano. Paródia, Paráfrase \&Cia. São Paulo: Ática, 2004.

SEPA, Fernanda M. O Teatro de William Butler Yeats: Teoria e Prática. São Paulo: Editora Olavobrás/ABEI, 1999.

SEYMOUR, St. John D. e NELIGAN, Harry L.(org.) True Irish Ghost Stories. New York: Galahad Books, 1993.

STEVENS, Kera e MUTRAN, Munira. O Teatro Inglês da ldade Média até Shakespeare. São Paulo: Global, 1988.

STEWART, Bruce.(Ed.) That Other World: The Supernatural and the Fantastic in Irish Literature and its Contexts. Gerrards Cross, U.K.: Colin Smythe, 1998. Vols. 1 \&2. 
STOKER, Bram. Dracula. London: Penguin Books, 2007. (1a edição: 1897)

SQUIRE, Charles. Mitos e Lendas Celtas. Rio de janeiro: Nova Era, 2003.

SÚILLEABHÁIN, Séan Ó. Storytelling in Irish Tradition. Cork: Mercier Press, 1973.

SZONDI, Peter. Teoria do Drama Moderno. São Paulo: Cosac Naify, 2001.

TODOROV, T. Introdução à Literatura Fantástica. São Paulo: Perspectiva, 2004.

TREMAYNE, Peter (Ed.) Irish Masters of Fantasy. Dublin: Wolfhound Press, 1979.

VARANDAS, Angélica. Mitos e Lendas Celtas: Irlanda. Lisboa: Livros e Livros, 2006.

WALLACE, Clare. (ed.) Monologues: Theatre, Performance, Subjectivity. Prague: Litteraria Pragensia, 2006a. . Suspect Cultures. Narrative, identity \& citation in 1990s new drama. Prague: Litteraria Pragensia, 2006b.

WATT, S. et al (Eds.). A Century of Irish Drama: Widening the stage. Bloomington: Indiana University Press, 2000.

WOOD, Gerald C. Conor McPherson Imagining Mischief. Dublin: The Liffey Press, 2003.

YAGI, Naoko. "Multiple Monologues as a narrative: From Beckett to McPherson" In: MIKAMI, H. et al (Eds.). Ireland on Stage: Beckett and after. Dublin: Carysfort Press, 2007, p.107-119.

YEATS, William Butler. Irish Fairy and Folk Tales. New York: The Modern Library, 2003. ( $1^{\text {st }}$ ed. 1918). 


\section{SITES}

BRANTLEY, Ben. Theater Review: A Most Dramatic Drama Critic. New York Times, 18/03/1998. Disponível em:

http://theater.nytimes.com/mem/theater/treview.html?res=9E04E3D61339F93BA250C0A96E958260 Acesso em: 21/10/2008.

DUBLINKS. The Seafarer@The Abbey. Disponível em:

<http://www.dublinks.com/index.cfm/loc/1/pt/0/spid/718E6E13-C1A1-65F5-B4958EB880351C6E.htm> Acesso em: 09/06/2008.

DOPPELGÄNGER. Disponível em: <http://pt.wikipedia.org/wiki/Doppelganger> Acesso em: 22/11/2008.

HAUN, Harry. The Seafarer - The Blind and the Blind-Drunk.

Disponível em: <www.playbill.com/features/article/print/113513.html>. Acesso em: 19/10/2008.

OUIJA BOARD. Disponível em: <http://pt.wikipedia.org/wiki/Tabuleiro Ouija>. Acesso em: 19/12/2008.

PRESSLEY, Nelson.Spirits That Haunt an Irish Writer. Disponível em:

<http://www.washingtonpost.com/wp-dyn/content/article/2007/11/09/AR2007110900611.html>.

Acesso em: 10/09/2008.

RAWSON, C. Irish playwright Conor McPherson chases away the demons.

Disponível em: <http://www.post-gazette.com/pg/09022/943433-325.stm>.

Acesso em: 20/05/2009.

THE LOWRY. An interview with Connor McPherson. Warning: contains plot spoilers. Disponível em:<http://www.thelowry.com/Shows/seafarer.html>. Acesso em: 14/01/2008. 